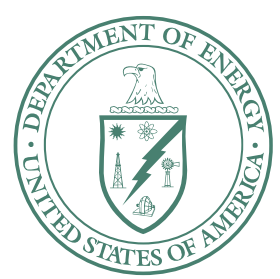

U.S. Department of Energy

Idaho Operations Office

\title{
Operable Unit 3-13, Group 3, Other Surface Soils (Phase II) Field Sampling Plan
}

July 2006 
DOE/ID-11256

Revision 0

\section{Operable Unit 3-13, Group 3, Other Surface Soils (Phase II) Field Sampling Plan}

July 2006

Prepared for the 


\begin{abstract}
This Field Sampling Plan describes the Operable Unit 3-13, Group 3, Other Surface Soils, Phase II remediation field sampling activities to be performed at the Idaho Nuclear Technology and Engineering Center located within the Idaho National Laboratory Site. Sampling activities described in this plan support characterization sampling of new sites, real-time soil spectroscopy during excavation, and confirmation sampling that verifies that the remedial action objectives and remediation goals presented in the Final Record of Decision for Idaho Nuclear Technology and Engineering Center, Operable Unit 3-13 have been met.
\end{abstract}




\section{CONTENTS}

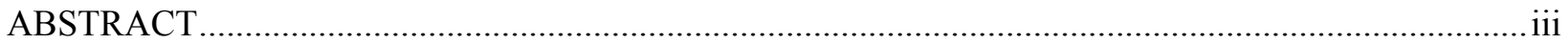

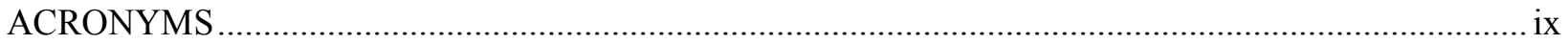

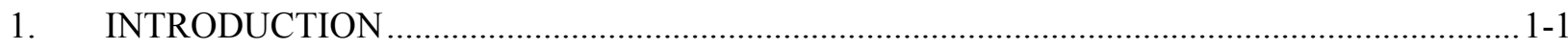

1.1 Field Sampling Plan Objectives ......................................................................... $1-1$

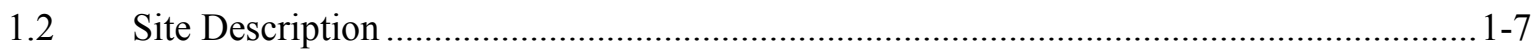

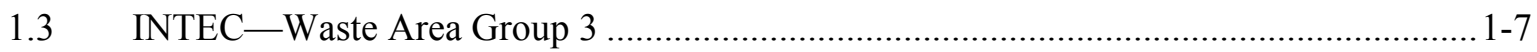

1.4 Operable Unit 3-13, Group 3, Phase II, Other Surface Soils........................................ 1-7

1.4.1 Group 3 Sites with No Sampling and Analysis Requirements......................1-10

1.4.2 Site Characterization Sampling and Analysis ......................................... 1-10

1.4.3 Site Confirmation Sampling and Analysis ............................................... 1-11

2. PROJECT ORGANIZATION AND RESPONSIBILITIES …................................................2-1

3. SAMPLING AND DATA QUALITY OBJECTIVES .......................................................

3.1 Data Quality Objectives …................................................................................... 3-1

S.1.1 State the Problem ................................................................................ $3-1$

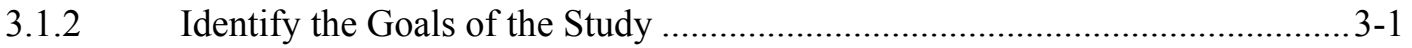

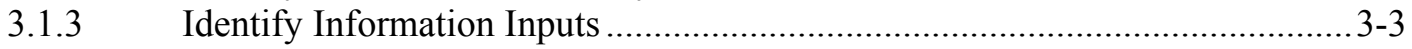

3.1.4 Define the Boundaries of the Study …......................................................... 3-3

3.1.5 Develop the Analytical Approach ................................................................. 3-4

3.1.6 Specify Performance or Acceptance Criteria ................................................ 3-5

3.1.7 Develop the Plan for Obtaining Data .......................................................... 3-7

3.2 Measurement Performance Criteria ........................................................................ 3-11

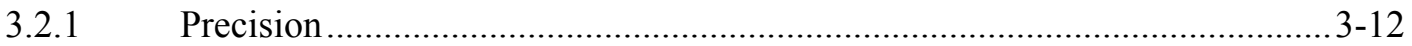

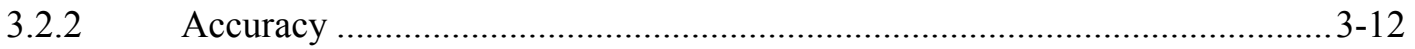

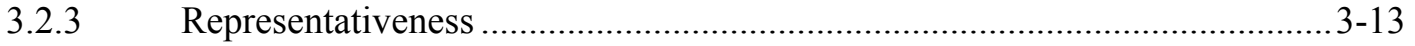

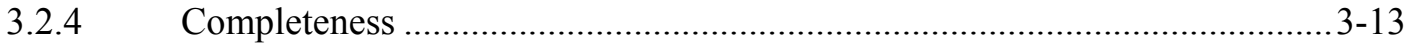

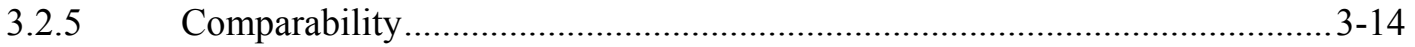

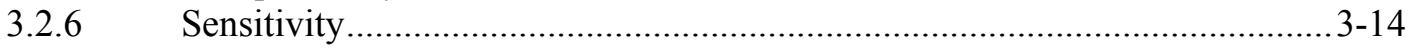

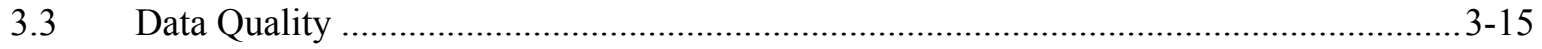

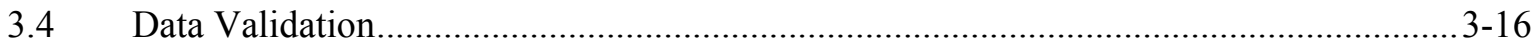


4.1 Soil Sample Collection and Analysis Strategies...................................................... 4-1

4.1.1 Pre Sampling Meeting ........................................................................... $4-1$

4.1.2 Characterization Sampling and Analysis (PSQ-1) ...................................... 4-1

4.1.3 Confirmation Sampling and Analysis (PSQ-2) and (PSQ-3) .........................4-3

4.2 Field Sampling and Analysis Requirements........................................................ $4-6$

4.2.1 General Field Sampling Requirements .................................................... 4-6

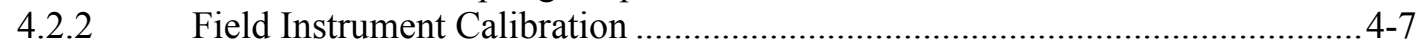

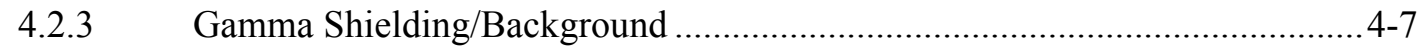

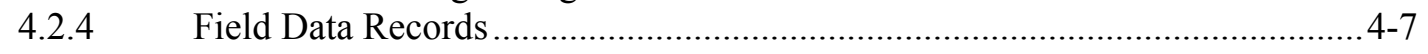

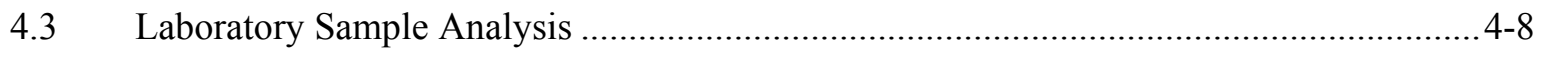

4.3.1 Analytical Methods ......................................................................... $4-8$

4.3.2 Instrument Calibration Procedures ............................................................ 4-14

4.3.3 Laboratory Records ............................................................................ $4-14$

4.4 Personal Protective Equipment............................................................................ $4-14$

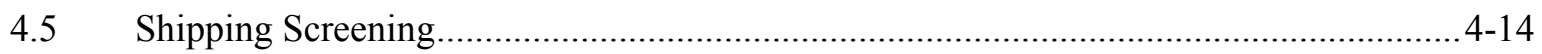

4.6 Field Decontamination ..................................................................................... 4-15

4.7 Sampling Waste Handling and Disposition .......................................................... $4-15$

4.8 Data Management and Document Control ............................................................ 4-15

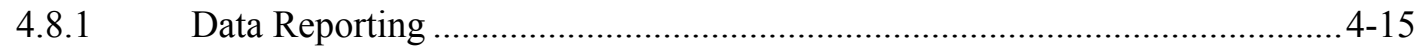

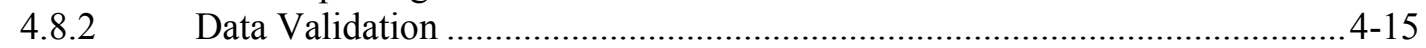

4.8.3 Data Quality Assessment ............................................................. 4-15

4.8.4 Document Control .................................................................. 4 -16

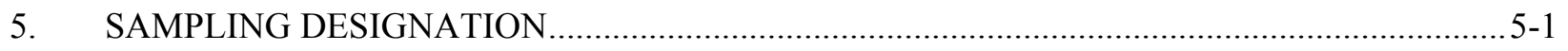

5.1 Sample Identification Code ….......................................................................... $5-1$

5.2 Sampling and Analysis Plan Table/Database ...........................................................5-1

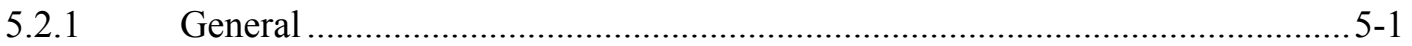

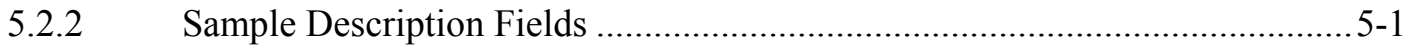

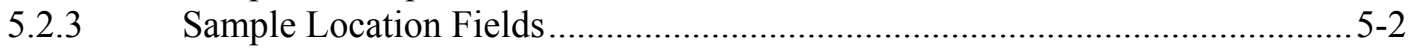

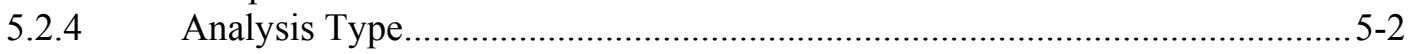


6. DOCUMENTATION MANAGEMENT AND SAMPLE CONTROL ....................................... $6-1$

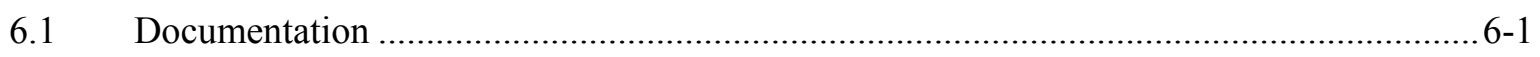

6.1.1 Sample Container Labels .......................................................................... $6-1$

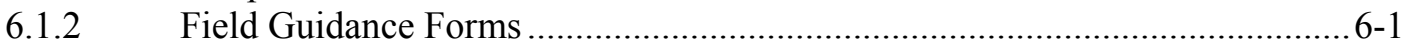

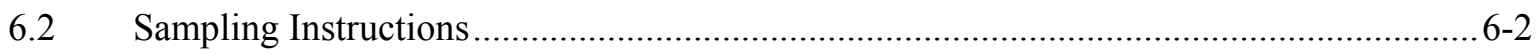

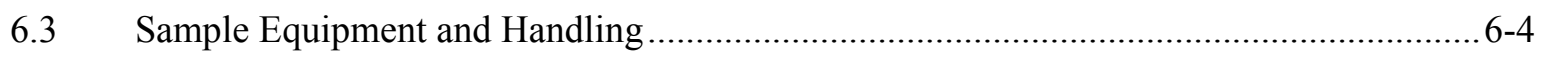

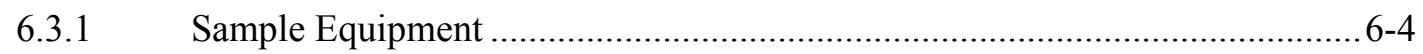

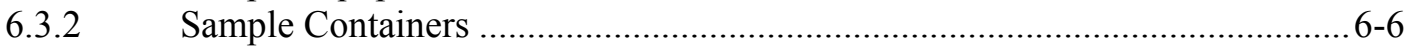

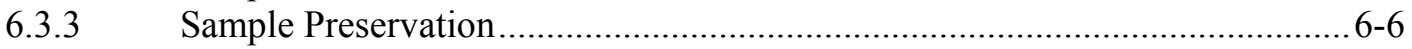

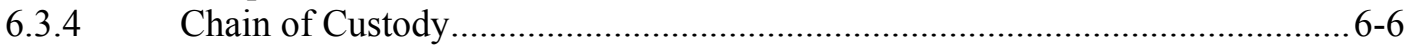

6.3.5 Transportation of Samples ............................................................... $6-8$

6.4 Documentation Revision Requests ........................................................................... 6-9

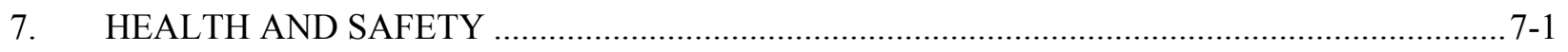

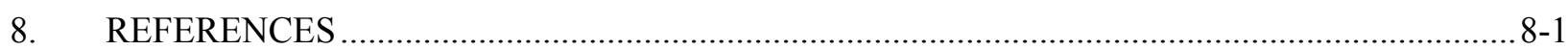

Appendix A-Group 3, Phase II Sites with Contaminants of Concern Exceeding Remediation

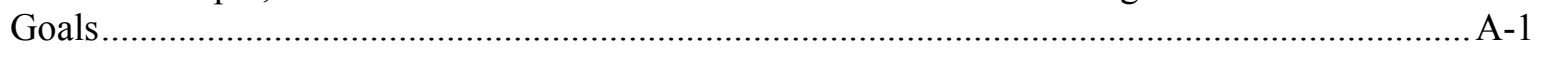

Appendix B - Group 3, Phase II Sites Sampling Location Figures .................................................... B-1

Appendix C —Sample and Analysis Plan Tables.............................................................................. C-1

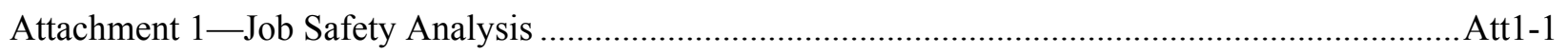

Attachment 2-Hazard Screening Checklist Hazard Screening Questions ......................................Att2-1

\section{FIGURES}

1-1. Location of the Idaho National Laboratory ....................................................................... 1-8

1-2. Operable Unit 3-13, Group 3, Other Surface Soils, (Phase II) sites .......................................... 1-9

3-1. Hypothetical site with 10-ft excavation sloped to the excavation boundary .............................. 3-11

4-1. CPP-124 characterization sample locations ….................................................................. $4-2$

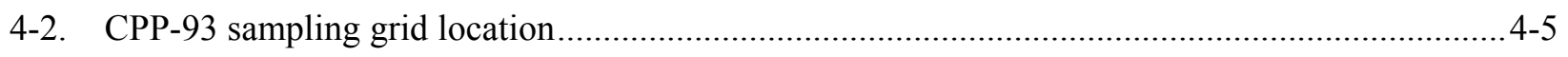




\section{TABLES}

1-1. Risk-based remediation goals for Operable Unit 3-13 soils ................................................... 1-2

1-2. Operable Unit 3-13, Group 3, Other Surface Soils (Phase II) sites ............................................ 1-3

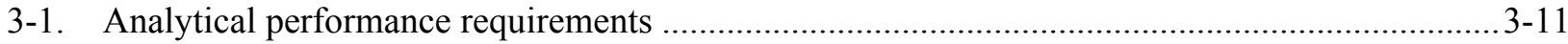

3-2. Laboratory analytical methods and detection limits for each contaminant of concern ................3-15

3-3. Field real-time spectroscopy instrumentation and detection limits for each contaminant

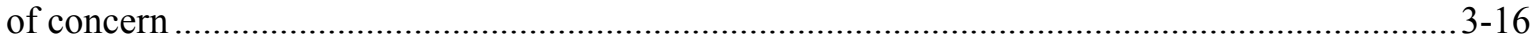

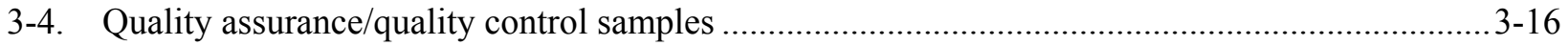

4-1. Summary of Group 3 Phase II sites requiring real-time spectroscopy and confirmation sampling

4-2. Summary of sample collection, holding time, and preservation requirements for radiological analyses

4-3. Summary of sample collection, holding time, and preservation requirements for samples collected for inorganic and organic analyses.

6-1. Sampling bottles, preservation types, and holding times ........................................................ 6-7

6-2. Quality control liquids sampling bottles, preservation types, and holding times ........................ 6-8 


\section{ACRONYMS}

AA alternative action

BaSIS Backpack Sodium Iodide System

BaSS Backpack Spectroscopy System

bgs below ground surface

CERCLA Comprehensive Environmental Response, Compensation and Liability Act

CFR Code of Federal Regulations

CLP Contract Laboratory Program

COC contaminant of concern

COPC contaminant of potential concern

CPP Chemical Processing Plant

DOE U.S. Department of Energy

DOE-ID U.S. Department of Energy Idaho Operations Office

EPA U.S. Environmental Protection Agency

ES Environmental Services

FSP field sampling plan

GDE guide

HPGe high-purity germanium

ICDF Idaho CERCLA Disposal Facility

ICP Idaho Cleanup Project

INL Idaho National Laboratory

INTEC Idaho Nuclear Technology and Engineering Center

JSA job safety analysis

JSS job site supervisor

MARSSIM Multi-Agency Radiation Survey and Site Investigation Manual

MCP management control procedure 


\begin{tabular}{|c|c|}
\hline OU & operable unit \\
\hline P\&T & Packaging \& Transportation \\
\hline PCB & polychlorinated biphenyl \\
\hline PLN & plan \\
\hline PM & project manager \\
\hline PSQ & principal study question \\
\hline QA & quality assurance \\
\hline QAPjP & Quality Assurance Project Plan \\
\hline QC & quality control \\
\hline $\mathrm{RD} / \mathrm{RA}$ & Remedial Design/Remedial Action \\
\hline $\mathrm{RG}$ & remediation goal \\
\hline ROD & Record of Decision \\
\hline RWMC & Radioactive Waste Management Complex \\
\hline SOW & Statement of Work \\
\hline SVOC & semivolatile organic compound \\
\hline SWP & Service Waste Pond \\
\hline TAL & target analyte list \\
\hline USC & United States Code \\
\hline VOC & volatile organic compound \\
\hline WCF & Waste Calcining Facility (CPP-633) \\
\hline WGS & Waste Generator Services \\
\hline
\end{tabular}




\section{Operable Unit 3-13, Group 3, Other Surface Soils (Phase II) Field Sampling Plan}

\section{INTRODUCTION}

In accordance with the Federal Facility Agreement and Consent Order for the Idaho National Engineering Laboratory (DOE-ID 1991), the U.S. Department of Energy (DOE) submits the following remedial action Field Sampling Plan (FSP) for the Idaho National Laboratory (INL), Operable Unit (OU) 3-13, Group 3, Other Surface Soils (Phase II). This FSP provides guidance for the collection of samples needed to support the remediation of the Other Surface Soils Phase II sites.

This FSP is implemented with the latest revision of the Quality Assurance Project Plan for Waste Area Groups 1, 2, 3, 4, 5, 6, 7, 10 and Inactive Sites (QAPjP) (DOE-ID 2004a), which provides guidance for sampling, quality assurance (QA), quality control (QC), analytical procedures, and data management. Together, the QAPjP and this FSP constitute the remedial action Sampling and Analysis Plan. The QAPjP describes the objectives and QA/QC protocols that will achieve the specified data quality objectives. In addition to the QAPjP, the Quality Assurance Project Plan for Environmental Services Characterization Sampling (PLN-524, Rev 4) was used in developing this FSP. Use of this FSP will help ensure that data are scientifically valid, defensible, and of known and acceptable quality, while use of the QAPjP will ensure that the data generated are suitable for their intended purposes.

The QAPjP and this FSP have been prepared pursuant to the Guidance for Conducting Remedial Investigations and Feasibility Studies under CERCLA (EPA 1988), the Federal Facility Agreement and Consent Order (DOE-ID 1991), and company policies and procedures.

\subsection{Field Sampling Plan Objectives}

The overall objective of this FSP is to guide the collection and analyses of sample data during implementation of the selected remedial actions for OU 3-13, Group 3, Other Surface Soils, presented in the OU 3-13 Record of Decision (DOE-ID 1999). The primary Record of Decision-selected remedy for this remedial action includes excavating the soils, disposing of them appropriately, performing confirmation sampling, and backfilling the excavation with clean fill.

Based on the data quality objectives developed in Section 3.1 of this plan, this FSP will support the characterization of new sites or additional OU 3-13 sites, real-time soil spectroscopy, and postremediation sampling to confirm that the Comprehensive Environmental Response, Compensation and Liability Act (CERCLA) (42 USC § 9601 et seq.) Record of Decision-defined, remediation goals have been met to ensure protection of human health and the environment. Table 1-1 identifies the risk-based remediation goals for OU 3-13 soils. These contaminants of concern (COCs) will vary from site to site as stated in Table 1-2. The principal threat posed by the Group 3 sites is external exposure to contaminated soils. The selected remedies for the Group 3 sites will eliminate this threat by removing or capping the contaminated soils in those sites with COCs exceeding remediation goals. 
Table 1-1. Risk-based remediation goals for Operable Unit 3-13 soils.

Soil Risk-Based Remediation Goal for Single Contaminant of Concern

Contaminant of Concern (pCi/g or $\mathrm{mg} / \mathrm{kg}$ )

Radionuclides

Am-241

290

Cs-137

23

$\mathrm{Eu}-152$

270

$\mathrm{Eu}-154$

5,200

$\mathrm{Pu}-238$

670

$\mathrm{Pu}-239 / 240$

250

$\mathrm{Pu}-241$

56,000

Sr-90

223

Nonradionuclides

Mercury (human health)

23 
Table 1-2. Operable Unit 3-13, Group 3, Other Surface Soils (Phase II) sites.

\begin{tabular}{|c|c|c|c|c|}
\hline Site & Description & Waste Type & $\begin{array}{c}\text { COCs Exceeding } \\
\text { Soil Remediation Goals } \\
\end{array}$ & Site Process Knowledge ${ }^{\mathrm{b}}$ \\
\hline CPP-01 & $\begin{array}{l}\text { Concrete settling basin and } \\
\text { dry wells east of CPP- } 633\end{array}$ & Soil and concrete & Cs-137, Sr-90 & $\begin{array}{l}\text { The fuel storage basin cleanup support system } \\
\text { received a slurry of filter aid (diatomaceous } \\
\text { earth) and shielding water. The filtered solids } \\
\text { (sludge) were periodically backwashed, } \\
\text { allowed to settle in CPP-301 and the } \\
\text { supernatant was discharged to deep dry well } \\
\text { CPP-303. Contaminants include only } \\
\text { radionuclides. }\end{array}$ \\
\hline CPP-04/05 & $\begin{array}{l}\text { Contaminated soil area } \\
\text { around CPP- } 603 \text { settling tank } \\
\text { and settling basin }\end{array}$ & Soil & $\begin{array}{l}\text { Cs-137, Sr-90, Eu-152, } \\
\text { Eu-154 }\end{array}$ & $\begin{array}{l}\text { The sites were combined because the } \\
\text { contamination resulted from an unintentional } \\
\text { release of sludge from the fuel storage basin } \\
\text { cleanup support system. Contaminants include } \\
\text { only radionuclides. }\end{array}$ \\
\hline СРP-08/09 & $\begin{array}{l}\text { Basin filter system line } \\
\text { failure and soil contamination } \\
\text { at northeast corner of } \\
\text { CPP-603 south basin }\end{array}$ & Soil & Cs-137 & $\begin{array}{l}\text { The sites were combined because the } \\
\text { contamination resulted from a release of } \\
\text { radionuclide-contaminated water from the } \\
\text { CPP- } 603 \text { basin. The exact location of the } \\
\text { carbon steel filter system line leak was never } \\
\text { determined. The line was replaced, and soil } \\
\text { samples were taken from a single borehole } \\
\text { in CPP-08. Contaminants include only } \\
\text { radionuclides. }\end{array}$ \\
\hline CPP-10 & $\begin{array}{l}\text { CPP-603 plastic pipeline } \\
\text { break }\end{array}$ & Soil and asphalt & Cs-137, Sr-90 & $\begin{array}{l}\text { Asphalt and soil outside the building } \\
\text { were contaminated from a release of } \\
\text { radionuclide-contaminated water from } \\
\text { the CPP- } 603 \text { storage basin water filter system. } \\
\text { No remediation of the contaminated was } \\
\text { performed, but several inches of clean soil } \\
\text { was placed over the contamination area. } \\
\text { Contaminants include only radionuclides. }\end{array}$ \\
\hline
\end{tabular}


Table 1-2. (continued).

\begin{tabular}{|c|c|c|c|c|}
\hline Site & Description & Waste Type & $\begin{array}{c}\text { COCs Exceeding } \\
\text { Soil Remediation Goals } \mathrm{a}\end{array}$ & Site Process Knowledge ${ }^{\mathrm{b}}$ \\
\hline CPP-11 & $\begin{array}{l}\text { CPP-603 sludge and water } \\
\text { release }\end{array}$ & Soil & Cs-137, Sr-90 & $\begin{array}{l}\text { The contamination at CPP- } 11 \text { resulted from } \\
\text { a release of contaminated sludge and water } \\
\text { from CPP- } 603 \text {. Contaminated soil with } \\
\text { radiation levels greater than } 1 \mathrm{R} / \mathrm{hr} \text { was } \\
\text { removed. Contaminants include metals } \\
\text { and radionuclides. }\end{array}$ \\
\hline CPP-13 & $\begin{array}{l}\text { Release from the } \\
\text { pressurization of calcine } \\
\text { storage cyclone northeast } \\
\text { of CPP-633 }\end{array}$ & Soil & Cs-137, Sr-90 & $\begin{array}{l}\text { The contamination over the berm area was } \\
\text { due to an air release of calcined, } \\
\text { radionuclide-contaminated waste. The } \\
\text { contamination was left in place and covered } \\
\text { with } 6 \text { in. of clean soil. Contamination is } \\
\text { assumed to extend from the berm surface } \\
\text { ( } 25 \mathrm{ft} \text { high) to } 2.5 \mathrm{ft} \text { below the berm (i.e., bgs). } \\
\text { Contaminants include metals and } \\
\text { radionuclides. }\end{array}$ \\
\hline СРP-19 & $\begin{array}{l}\text { CPP-603 to CPP-604 line } \\
\text { leak }\end{array}$ & Soil & $\begin{array}{l}\text { Cs-137, Sr-90, Eu-152, } \\
\text { Eu-154 }\end{array}$ & $\begin{array}{l}\text { The underground waste transfer line was } \\
\text { abandoned in place after a leak of } \\
\text { radionuclide-contaminated liquid was } \\
\text { discovered. Contaminants include } \\
\text { radionuclides. }\end{array}$ \\
\hline CPP-35 & CPP-633 decon spill & Soil & Cs-137, Sr-90 & $\begin{array}{l}\text { Contamination at CPP- } 35 \text { results from a } \\
\text { release of decontamination liquid that entered } \\
\text { the WCF systems and was ultimately released } \\
\text { to the soil. The solution contained nitric acid, } \\
\text { mercuric nitrate, heavy metals, inorganic } \\
\text { compounds and radionuclides. Contaminated } \\
\text { soil and gravel were removed and shipped to } \\
\text { the RWMC. No contaminants were detected } \\
\text { below } 7 \mathrm{ft} \text {. Contaminants include metals and } \\
\text { radionuclides. }\end{array}$ \\
\hline
\end{tabular}


Table 1-2. (continued).

\begin{tabular}{|c|c|c|c|c|}
\hline Site & Description & Waste Type & $\begin{array}{c}\text { COCs Exceeding } \\
\text { Soil Remediation Goals } \\
\end{array}$ & Site Process Knowledge ${ }^{\mathrm{b}}$ \\
\hline \multirow[t]{3}{*}{ CPP-36 } & $\begin{array}{l}\text { Transfer line leak from } \\
\text { CPP-633 }\end{array}$ & Soil & $\begin{array}{l}\text { Note: } \mathrm{Pu}-238,239 \text {, and } \\
240 \text { are not expected to } \\
\text { be encountered at depths }\end{array}$ & $\begin{array}{l}\text { In } 1970 \text { highly contaminated soil was } \\
\text { encountered at a depth of } 6 \mathrm{ft} \text { beneath } \\
\text { Olive Ave. The exact location of the release } \\
\text { source is unknown. The contaminated soil } \\
\text { was excavated and disposed at RWMC. Clean } \\
\text { fill was used as backfill. In } 1974 \text { contaminated } \\
\text { soil was again encountered during an } \\
\text { excavation. Three samples were collected, but } \\
\text { the depths are unknown. }\end{array}$ \\
\hline & & & & $\begin{array}{l}\text { The initial area of CPP- } 36 \text { was expanded } \\
\text { because contamination was found above } \\
\text { background levels in "observation wells." }\end{array}$ \\
\hline & & & & $\begin{array}{l}\text { The CPP- } 36 \text { Area of Contamination was } \\
\text { expanded to include CPP- } 91 \text { because } \\
\text { contamination at both sites was } \\
\text { indistinguishable. Samples from boreholes } \\
\text { were analyzed for metals, inorganics, VOCs, } \\
\text { and radionuclides. No VOCs were detected } \\
\text { above background. Contaminants include } \\
\text { metals and radionuclides. }\end{array}$ \\
\hline СРP-93 & $\begin{array}{l}\text { Simulated calcine disposal } \\
\text { trench }\end{array}$ & Soil \& Simulated Calcine & $\mathrm{Hg}$ & $\begin{array}{l}\text { In the early } 1960 \text { s a trench was used to dispose } \\
\text { of simulated calcine test batches. One test } \\
\text { batch contained mercuric nitrate. The trench } \\
\text { contains a layer of nonradioactive calcine } \\
\text { covered by } 4 \mathrm{ft} \text { of backfill. Initially, more than } \\
60 \text { borings were drilled in the trench area and } \\
\text { additional borings confirmed that lateral soil } \\
\text { contamination beyond the trench has not } \\
\text { occurred. The only contaminant of concern is } \\
\text { mercury (Hg). }\end{array}$ \\
\hline
\end{tabular}


Table 1-2. (continued).

\begin{tabular}{|c|c|c|c|c|}
\hline Site & Description & Waste Type & $\begin{array}{c}\text { COCs Exceeding } \\
\text { Soil Remediation Goals }\end{array}$ & Site Process Knowledge $\mathrm{e}^{\mathrm{b}}$ \\
\hline СРP-124 & $\begin{array}{l}\text { Leak east of CPP- } 601 \\
\text { (New Site) }\end{array}$ & Soil & TBD & $\begin{array}{l}\text { During the transfer of process condensate } \\
\text { (PEWE overhead Condensate) from } \\
\text { CPP-604/605 to the service waste system, } \\
\text { three small leaks were observed. No soil data is } \\
\text { available. Data is available for the liquid } \\
\text { condensate and from nearby CERCLA site } \\
\text { CPP- } 58 \text { west. Potential contaminate of concern } \\
\text { include metals, radionuclides and organics. }\end{array}$ \\
\hline
\end{tabular}

a. Remediation goals obtained from OU 3-13 Record of Decision (DOE-ID 1999).

b. Process knowledge obtained from OU 3-13 Record of Decision (DOE-ID 1999), Sections 5.3.2

and 5.3.3., or from New Site Identification (NSI) forms.

CERCLA $=$ Comprehensive Environmental Response, Compensation, and Liability Act $\mathrm{COC}=$ contaminant of concern

$\mathrm{COPC}=$ contaminants of potential concern

$\mathrm{CPP}=$ chemical processing plan

$\mathrm{RD} / \mathrm{RA}=$ Remedial Design/Remedial Action

ROD $=$ Record of Decision

RWMC $=$ Radioactive Waste Management Complex

SWP $=$ Service Waste Pond

$\mathrm{TBD}=$ to be determined

$\mathrm{VOC}=$ volatile organic compound

$\mathrm{WCF}=$ Waste Calcining Facility (CPP-633) 


\subsection{Site Description}

The INL Site encompasses $2,305 \mathrm{~km}^{2}\left(890 \mathrm{mi}^{2}\right)$ and is located approximately $55 \mathrm{~km}$ (34 mi) west of Idaho Falls in southeastern Idaho (Figure 1-1). The United States Atomic Energy Commission, now the DOE, established the Nuclear Reactor Testing Station, now the INL, in 1949 as a site for building and testing nuclear facilities. At present, the INL supports the engineering and operations efforts of DOE and other federal agencies in areas of nuclear safety research, reactor development, reactor operations and training, nuclear defense materials production, waste management and technology development, energy technology, and conservation programs.

\subsection{INTEC-Waste Area Group 3}

The Idaho Nuclear Technology and Engineering Center (INTEC), formerly known as the Idaho Chemical Processing Plant, is located in the south-central portion of the INL Site. From 1952 to 1992, operations at INTEC primarily involved reprocessing spent nuclear fuel from defense projects, which entailed extracting reusable uranium from the spent fuels. Liquid waste generated from the reprocessing activities, which ceased in 1992, is stored in an underground tank farm at INTEC. Both soil and groundwater contamination has resulted from these previous operations. Under the Federal Facility Agreement and Consent Order, the U.S. Environmental Protection Agency (EPA), Idaho Department of Environmental Quality, and U.S. Department of Energy Idaho Operations Office (DOE-ID) (collectively referred to hereafter as the Agencies) are directing cleanup activities to reduce human health and environmental risk to acceptable levels. The INTEC is designated as Waste Area Group 3, in accordance with the Federal Facility Agreement and Consent Order.

\subsection{Operable Unit 3-13, Group 3, Phase II, Other Surface Soils}

Waste Area Group 3 was subdivided into 14 operable units (OUs) that were investigated for contaminant releases to the environment. Fifty-five contaminant release sites were identified within OU 3-13 requiring remedial action to mitigate risks to human health and the environment under a future residential use scenario. These sites were then grouped into seven groups that share common characteristics and contaminant sources. Group 3, Other Surface Soils, is further divided into Remediation Sets 1 through 6. Eighteen of the 55 release sites are included in Sets 4, 5, and 6. The remediation of eleven sites from Sets 4, 5, will be completed as Phase II of the OU 3-13, Group 3, Other Surface Soils remediation project. Seven sites do not require any additional action as described in Section 1.4 of the Group 3 Phase II Remedial Design/Remedial Action (RD/RA) Work Plan (DOE-ID 2006a). Two additional sites have been added to the Group 3 Phase II RD/RA Work Plan and this FSP for evaluation. The sampling approach for these sites is discussed in the following sections. Figure 1-2 identifies the location of the Group 3, Other Surface Soil sites included in the Group 3 Phase II RD/RA Work Plan and this FSP.

The following two sites require characterization sampling:

- $\quad$ CPP-81 Abandoned 3-in. vessel off-gas line

- $\quad$ CPP-124 - Leak east of CPP-601. 


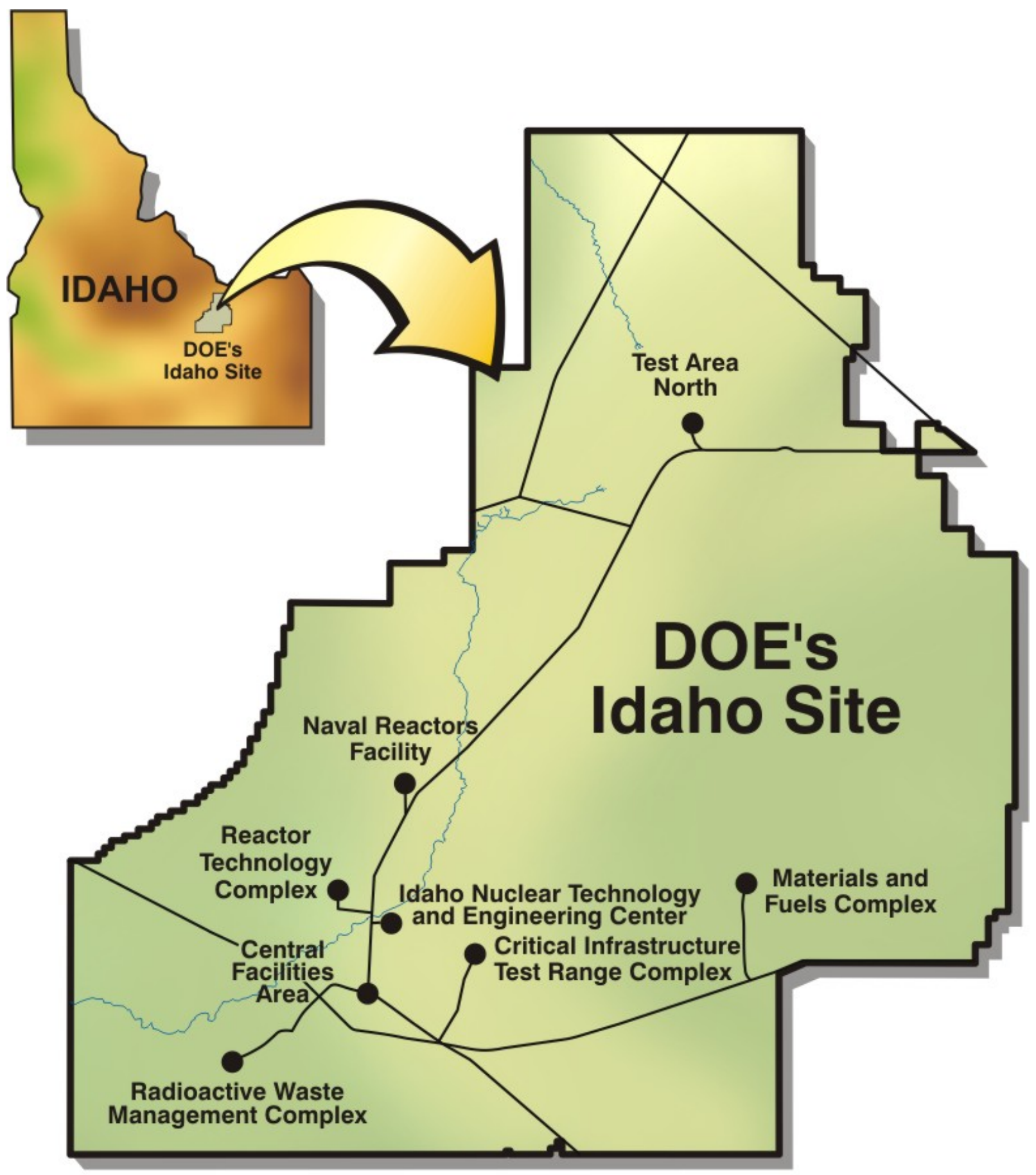

G1422-25

Figure 1-1. Location of the Idaho National Laboratory. 


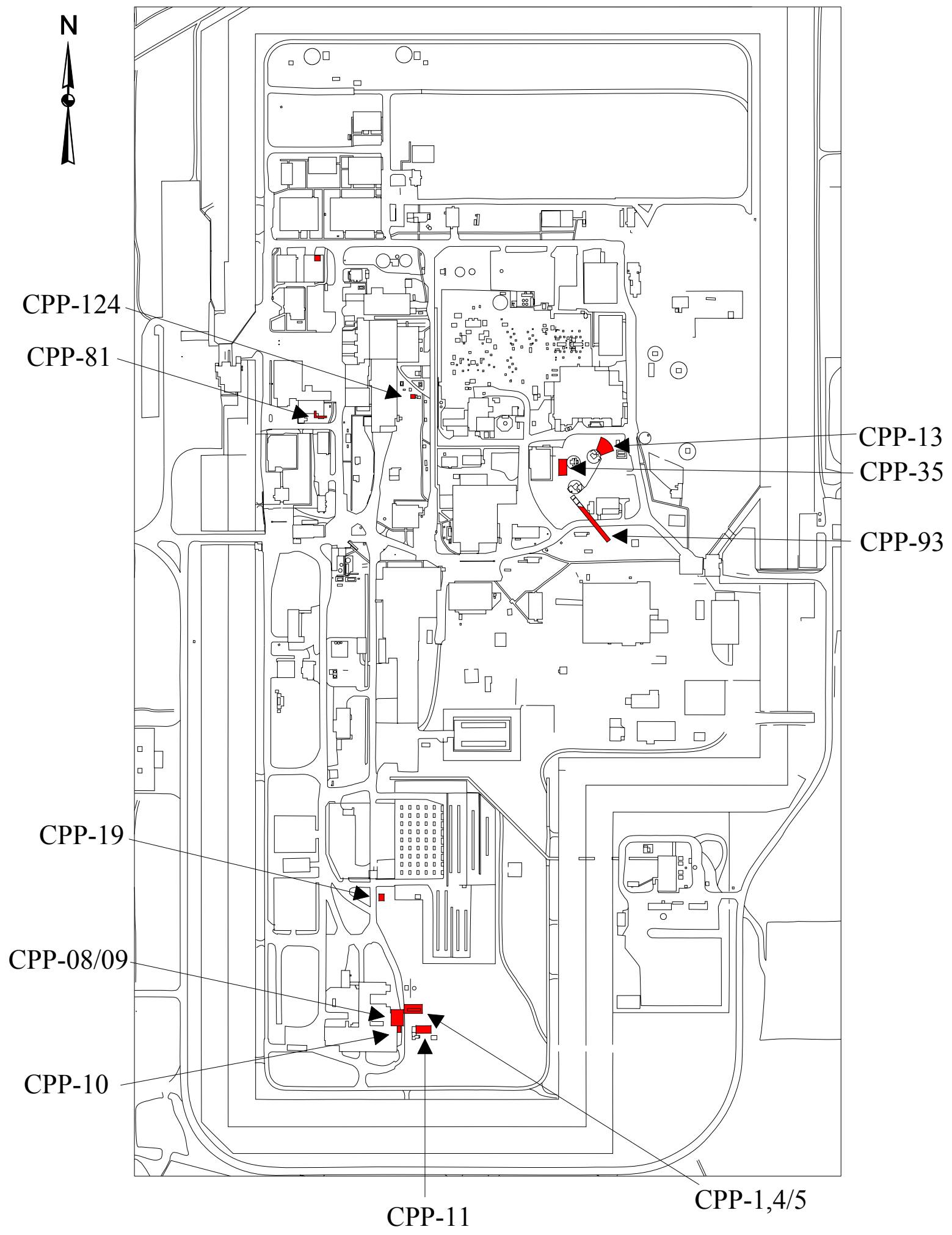

Figure 1-2. Operable Unit 3-13, Group 3, Other Surface Soils, (Phase II) sites. 
Brief site descriptions, waste types, COCs, waste stream constituents, and process knowledge summaries are provided in Table 1-2. In-depth site descriptions and discussion of process knowledge, and previous sampling and characterization efforts are contained in Section 1.4 of the Group 3, Phase II, Remedial Design/Remedial Action Work Plan (DOE-ID 2006a). Existing characterization data summary tables for all Group 3 Phase II sites can be found in Appendix A of the Work Plan. The detailed descriptions of each Group 3 Phase II site, the data summary tables, and the exposure pathway identified in the Phase II RD/RA Work Plan are elements of the conceptual site model for the Group 3 Phase II soil sites remediation. The figures in Appendix A support the OU 3-13 conceptual site model by illustrating the location, and nature of contamination in Group 3 Phase II sites not needing additional sampling and analysis.

\subsubsection{Group 3 Sites with No Sampling and Analysis Requirements}

The Group 3 Phase II RD/RA Work Plan identifies the following sites as not needing additional sampling and analysis:

- $\quad$ CPP-14 - Old Sewage Treatment Plant West of CPP-664

- $\quad$ CPP-41A - Fire Training Pits between CPP-666 and CPP-633, Under Asphalt

- $\quad$ CPP-44 - Grease Pit South of CPP-608

- $\quad$ CPP-48 - French Drain South of CPP-633

- $\quad$ CPP-55 - Mercury Contamination Area South of CPP T-15

- $\quad$ CPP-60 Paint shop at present location of CPP-645

- $\quad$ CPP-68 - Abandoned Gasoline Tank CPP-VES-UTI-652

- $\quad$ CPP-91 - CPP-633 Blower Pit Drain

- $\quad$ CPP-129 - Soils under the CPP-637 and CPP-620 Facilities.

If the remedial action decision status for any of these sites changes in the Group 3 Phase II Remedial Design/Remedial Action Work Plan, then this FSP will be revised.

\subsubsection{Site Characterization Sampling and Analysis}

One site has been included in the Group 3 Phase II RD/RA Work Plan as requiring initial or additional characterization to determine to need for remedial action. This site includes:

- $\quad$ CPP-124 - Leak east of CPP-601.

This site requires initial characterization sampling and analysis because only limited existing data from previous sampling events (or process knowledge concerning soil contamination) is available. Site CPP-124 will require sampling and analysis for volatiles, semi-volatile, metals, and radionuclides. Detailed sampling and analysis requirements for this site can be found in Section 4.

Following an evaluation of the characterization data for these sites, it will be determined if additional remedial action is required. If necessary, remediation of this site will be performed as described in the Group 3 Phase II RD/RA Work Plan (DOE-ID 2006a). 
Site CPP-36 has been identified as potentially having I-129 contamination as discussed in the Group 3 Phase II RD/RA Work Plan Section 1.3.4. Characterization samples may be collected during excavation and prior to disposal per the Idaho CERCLA Disposal Facility (ICDF) Waste Acceptance Criteria (WAC).

\subsubsection{Site Confirmation Sampling and Analysis}

Confirmation sampling and analysis will be performed on all Group 3 Phase II sites soil with COCs above remediation goals and where remediation will be performed (with the exception of site CPP-81 where the contaminants are completely contained in the pipeline). All of the following sites will be remediated and require real-time spectroscopy confirmation analysis following excavation operations:

- $\quad$ CPP-01 - Concrete Settling Basins and Dry Wells East of CPP-603

- $\quad$ CPP-04/05 - Contaminated Soil Area Around CPP-633 Settling Tanks and Settling Basin

- $\quad$ CPP-08/09 - Basin Filter System Line Failure and Soil Contamination at NE Corner of CPP-603 South Basin

- $\quad$ CPP-10 - CPP-603 Plastic Line Leak

- $\quad$ CPP-11 - CPP-603 Sludge and Water Release

- $\quad$ CPP-13 - Pressurization of Solid Storage Cyclone Release NE CPP-633

- $\quad$ CPP-19 - CPP-603 to CPP-604 Line Leak

- $\quad$ CPP-35 - CPP-633 Decontamination Spill

- $\quad$ CPP-36 - Transfer Line Leak from CPP-63.

Confirmation analysis includes field deployed real-time spectroscopy for radionuclides (i.e., C-137, $\mathrm{Eu}-152, \mathrm{Eu}-154)$, laboratory analysis for gross beta or total strontium (i.e., Sr-90), and a field deployed mercury analyzer. Samples will be collected for mercury and strontium analysis. Section 4.0 and Table 4-1 summarize the real-time spectroscopy and confirmation analyses required for each Group 3 Phase II site discussed in this FSP.

1.4.3.1 Real-Time Spectroscopy. All of the above listed sites will have Cs-137 and Eu-152/154 confirmation analysis performed using real-time spectroscopy instrumentation following excavation on sloped soils above $10 \mathrm{ft}$. This confirmation analysis following excavation will be used to confirm that soil contamination has been removed to below remediation goals. If contamination is found above the remediation goals, the soil will be remediated laterally until real-time spectroscopy results indicate COCs are below remediation goals.

The field deployed real-time spectroscopy methods include the Backpack Spectroscopy System (BaSS) and high-purity germanium (HPGe) instrumentation. (Note: Gas flow proportional beta detectors are available and may be deployed in the future for real-time Sr-90 conformation analysis.) These real-time spectroscopy methods are non-invasive surface soil analysis techniques that require no physical soil samples to obtain quantitative results. The site confirmation strategy is discussed in more detail in Section 4.

Existing analytical data for Group 3 site CPP-36 identifies Cs-137, Am-241, Pu-238, and $\mathrm{Pu}-239 / 241$ as contaminants of concern above remediation goals. The results for these COCs are at a depth greater than $10 \mathrm{ft}$ below ground surface (bgs). 
1.4.3.2 Mercury and Strontium Confirmation Sampling and Analysis. Confirmation sampling and analysis will be performed for mercury at site CPP-93 using field deployed real-time instrumentation. Site CPP-93 was a trench that was filed with simulated calcine containing small amounts of mercury nitrate. Consequently, confirmation sampling will only be performed on the bottom of the excavation area. The mercury contamination may have migrated to the soil below the simulated calcine trench; it is not expected to have migrated laterally into the surrounding soil. Section 4.1 discusses the sampling strategy for sample collection and the mercury analysis instrumentation that will be deployed at site CPP-93.

The existing site data and Figures in Appendix A of the Group 3 Phase II RD/RA Work Plan indicated that all of the Phase II sites listed above (except CPP-04/05 and CPP-10) will require Sr-90 confirmation sampling and analysis following site remediation. Samples will be collected and sent to an analytical laboratory for gross beta or total strontium analysis. The sampling strategy for Sr-90 confirmation sampling is discussed in greater detail in Section 4.2. 


\section{PROJECT ORGANIZATION AND RESPONSIBILITIES}

The Miscellaneous Sites Cleanup Project is one of the four cleanup areas specified in the U.S. Department of Energy (DOE) Contract DE-AC07-05ID14516. A detailed description of the project organization, team member responsibilities, and interface responsibilities are described in the Miscellaneous Sites Cleanup Project Health, Safety, and Work Control Plan (PLN-2128).

The Miscellaneous Sites Cleanup Project has responsibility for CERCLA activities under the Federal Facility Agreement and Consent Order (DOE-ID 1991) that include:

- $\quad$ Programmatic responsibility for Idaho Cleanup Project (ICP) CERCLA activities at Test Reactor Area (TRA) (now Reactor Technology Complex [RTC]), INTEC, the Power Burst Facility (PBF)/Auxiliary Reactor Area (ARA), Central Facilities Area (CFA) and Test Area North (TAN). The Miscellaneous Sites Cleanup project is not responsible for CERCLA operations at the ICDF and RWMC Waste Area Group 7 specific remedial actions.

- $\quad$ Programmatic responsibility and coordination for all Voluntary Consent Order characterization and closure for the ICP.

- Groundwater monitoring.

- $\quad$ Long-term stewardship activities.

- Implementation and maintenance of institutional control actions.

- Coordination and resolution of Resource Conservation and Recovery Act/CERCLA (42 USC § 6901 et seq.; 42 USC $\S 9601$ et seq.) interface issues.

The Miscellaneous Sites Cleanup Project interfaces with internal and external organizations and other stakeholders who have an interest in the progress of accomplishing the cleanup work. Interface agreements are prepared and approved by the project and facility management to ensure that boundaries, duties, and responsibilities are assigned. These interface agreements are simple, one-page documents that identify activities necessary to accomplish tasks, the responsible organization, and the responsible manager. 


$$
\text { 2-2 }
$$




\section{SAMPLING AND DATA QUALITY OBJECTIVES}

\subsection{Data Quality Objectives}

The sampling objectives are discussed in the context of the data quality objectives process as defined by Guidance on Systematic Planning Using the Data Quality Objectives Process (EPA 2006). This process was developed by the Environmental Protection Agency to ensure that the type, quantity, and quality of data used in decision-making are appropriate for the intended application. The data quality objective process includes seven steps, each of which has specific outputs. In this document, the data quality objective process has been applied to the sampling activities associated with identifying the extent of contamination at the OU 3-13 sites listed in Table 1-2. Each of the following sections corresponds to a step in the data quality objective process, and the outputs for each step are provided, as appropriate.

\subsubsection{State the Problem}

The first step in any systematic planning process, and therefore the data quality objective process, is to clearly state the problem to be addressed. The intent of this step is to clearly define the problem so that the focus of the sampling and analysis will be unambiguous. The appropriate outputs for this step are a concise description of the problem, a list of the planning team members, identification of the team of experts and stakeholders, a summary of available resources, and relevant deadlines for the study. The planning team members are identified and discussed in the health and safety plan (PLN-2128). The problem statements for the Group 3 Phase II sites remedial action is to:

- $\quad$ Determine the location and nature of contamination at new sites or other OU 3-13 sites added to the Group 3 Phase II Remedial Design/Remedial Action Work Plan

- Determine the extent of contamination using real-time soil spectroscopy methods

- Determine whether excavation is complete and any remaining soil contamination is below remediation goals using real-time soil spectroscopy instrumentation and/or sampling and analysis.

\subsubsection{Identify the Goals of the Study}

The primary objective of Step 2 in the data quality objective process is to identify key questions, along with alternative actions or outcomes that may result based on the answers. For decision-making, this involves combining the question and action into a decision statement (DS). For estimation, the study should be framed toward an estimation statement (ES).

The first goal is to estimate the nature, location, or extent of contamination for a new site in order to calculate exposure risks. A new site is any site that is either currently included in the Phase II Remedial Design/Remedial Action Work Plan or may be included in the Work Plan in the future as described in Section 1.3 of the Work Plan.

\section{Principal Study Question (PSQ)1: Estimate the mean COC concentrations in new site soils.}

- $\quad$ The estimates of mean COC concentrations in soil at the new sites are required to calculate exposure risk. 
Combining the principal study question and the associated outcome results in the following estimation statement:

ES1: The COC concentrations are to be estimated for new sites. The estimated concentrations are necessary to calculate exposure risk from the soils.

The following is a recursive principal study question; as the excavation face is scanned for radionuclide contamination in the soil using real-time soil spectroscopy instrumentation, this question will be constantly asked and answered until the contamination is removed for all soil above $10 \mathrm{ft}$ bgs.

The second objective is to determine if the Phase II soil sites have been remediated.

\section{PSQ2: Does the site after each excavation phase leave any COCs above the remediation goal?}

The alternative actions to be taken depending on the resolution to PSQ2 are as follows:

- $\quad \mathrm{AA} 2.1$ : If the COCs at the excavation face do not exceed the remediation goals, then excavation is complete.

- $\quad$ AA2.2: If the COCs at the excavation face exceed the remediation goals, then excavation continues until a maximum depth of $10 \mathrm{ft}$ bgs or the contamination is below the remediation goals.

- $\quad$ AA2.3: If the COCs in soil at $10 \mathrm{ft}$ bgs exceed the remediation goals, then record the concentration of contamination left in place and excavation is complete.

Combining the principal study question and the associated alternative actions results in the following decision statement:

DS1: Determine whether the site, following excavation, has COCs that are below remediation goals and excavation is complete or if the site, following excavation, has COCs that exceed the remediation goals and, thus, excavation must continue to a maximum depth of $10 \mathrm{ft}$ bgs.

The third objective of the sampling specified in this plan applies to sites for which excavation is complete. The objective is to confirm whether or not all of the contamination at the release has been excavated. This objective is met by answering the following principal study question:

\section{PSQ3: Have all COCs in the contaminated soil been remediated?}

The alternative actions to be taken depending on the resolution to PSQ3 are as follows:

- $\quad$ AA3.1: If all of the contaminated soil above $10 \mathrm{ft}$ bgs that exceeded the remediation goals has been removed, then the remediation is complete.

- $\quad$ AA3.2: If all of the contaminated soil above $10 \mathrm{ft}$ bgs that exceeded the remediation goals has not been removed, then excavation will continue, until confirmation sampling results indicate the contamination in the soil is below remediation goals.

Combining PSQ3 and the associated alternative actions results in the following decision statement: 
DS2: Determine whether or not soil contamination above $10 \mathrm{ft}$ bgs that exceeded the remediation goals at Group 3, Phase II sites has been completely removed and the remedial action is complete, or if contamination remains and excavation must continue.

\subsubsection{Identify Information Inputs}

The purpose of this step is to (a) identify informational inputs that are required to resolve the ES and DSs or produce the desired estimates, (b) determine which inputs require measurements, and (c) determine the information basis for establishing analysis approaches and performance criteria. The information needed to address ES1 is the identification and quantification of COCs in the soils associated with any sites. The information needed to address DS1 is the real-time soil spectroscopy data at the digface for the soil COCs present. The inputs for addressing DS2 are the quantification and confirmation of the soil COCs (Table 1-1) present in the soils remaining at the boundary of the excavation area to a depth of $10 \mathrm{ft}$ within the excavation area at the design excavation depth. The following information is required to resolve the one ES and two DSs identified above:

1. Historical field data, including location of sample collections

2. Historical analytical data that has been validated and can be used for characterization

3. Remediation goals

4. Acceptable risk limits

5. Calculation of risk for COCs without remediation goals

6. Scanning results

7. Analytical data from samples taken.

\subsubsection{Define the Boundaries of the Study}

The primary objectives of this step are to define the spatial and temporal boundaries that apply to each decision and estimation statement and identify practical constraints that must be considered in the sampling design. Implementing this step helps ensure that the sampling design will result in the collection of data that accurately reflect the true condition of the site under investigation.

The spatial extent of the OU 3-13 sampling effort pertains to the soils from the surface down to $10 \mathrm{ft}$ bgs associated with the Group 3, Phase II sites in Table 1-2 that have been identified as having concentrations of at least one COC in excess of the remediation goal identified in the Record of Decision or for which COC concentrations have not yet been determined. The spatial boundaries of concern for this sampling effort are originally confined to the soil areas within the Group 3, Other Surface Soils excavation boundaries or described in New Site Identifications. The excavation boundaries are assumed to be adequately defined for all sites, but may be expanded based on sample analysis results or scanning results during the excavation activities. Sites that have been determined to be uncontaminated are not within the study boundaries since it is not necessary to take further action at these sites (DOE-ID 2006a).

Additionally no excavation and or sampling will be performed at a depth greater than $10 \mathrm{ft}$ bgs. Efforts associated with the preparation of the OU 3-14 Remedial Investigation/Feasibility Study/Baseline Risk Assessment (RI/FS/BRA)have determined that no OU 3-13 Record of Decision COCs in the soil below $10 \mathrm{ft}$ are a threat to the Snake River Plain Aquifer, human health, or the environment. Institutional Controls will apply at Phase II sites where contamination is left in place below $10 \mathrm{ft}$ bgs. 
Defining the temporal boundaries of the study involves specifying the timeframe in which the decision applies and determining when to collect data. The time period within which to collect the data is determined by funding, schedule, and field operation limitations.

There are practical constraints expected to be encountered that would interfere with the collection of adequate soil samples for analyses. These constraints could include:

1. Inability to sample in some areas due to subsurface infrastructure, such as waste lines, water lines, and electrical lines

2. Facility Operations constraints

3. High radionuclide contamination

4. Physical structures, such as buildings and asphalt

5. Conflicts with other projects, such as Resource Conservation and Recovery Act, Voluntary Consent Order, and Transuranic (TRU) Waste Transportation.

\subsubsection{Develop the Analytical Approach}

The objective of this step is to develop an analytical approach that will guide how you analyze the study results and draw conclusions from the data. For decision problems, the theoretical decision rule is an unambiguous "If...then" statement. For estimation problems, this will result in a clear specification of the estimator. The step will define parameter(s) of interest that characterize the population, specify the action level, and integrate previous data quality objective outputs into a single statement.

The parameter of interest for ES1 depends on the type of site. If the site is believed to be contaminated with radiological COCs, then a scan would be performed and the parameter of interest would be the maximum scanning result. If the site is believed to be contaminated with non-radiological COCs, then sampling and analysis would be performed and the parameter of interested is the mean concentration, as estimated by the $95 \%$ upper confidence limit of concentrations of the COCs in the new Waste Area Group 3, Group 3 new soil sites. The parameter of interest for DS1 is the scanning results. The parameter of interest for DS2 is the scanning results for sites not requiring sampling and the mean concentration, as estimated by the $95 \%$ upper confidence limit of concentrations of COCs at the Waste Area Group 3, Group 3 soil sites that require confirmation sampling. The decision rules resulting from the previous data quality objective steps are as follows:

\section{Principle Study Question 1 (PSQ1)}

- The study will estimate the nature and extent of contamination at a new site using either the maximum scanning result or the mean concentration, as estimated by the $95 \%$ upper confidence limit

\section{Principle Study Question 2 (PSQ2)}

- If , at a given time during excavation any real-time spectroscopy result exceeds remediation goals, then the excavation of the site will continue.

- If , at a given time during excavation all real-time spectroscopy results are below remediation goals, then the excavation will be discontinued. 


\section{Principle Study Question 3 (PSQ3)}

- If, for each Group 3, Phase II site at the design excavation depth following soil excavation, any real-time spectroscopy result or the mean concentration, as estimated by the $95 \%$ upper confidence limit, exceeds remediation goals for any $\mathrm{COC}$ or the sum of fractions exceeds the combined COC remediation goal, then subsequent remediation activities will be evaluated as described in the project Remedial Design/Remedial Action Work Plan.

- If, for each Group 3, Phase II site at the design excavation depth following soil excavation, any real-time spectroscopy result or the mean concentration, as estimated by the $95 \%$ upper confidence limit does not exceed remediation goals for any $\mathrm{COC}$ and the sum of fractions does not exceed the combined COC remediation goal, then the site will be considered closed.

\subsubsection{Specify Performance or Acceptance Criteria}

Step 6 of the data quality objective process is used to derive the performance or acceptance criteria that the collected data must meet in order to minimize the possibility of either making erroneous conclusions or failing to keep uncertainty in estimates to within acceptable levels. The type of criteria to be set depends on the intended use of the data. For decision statements, this step is used to identify the hypotheses associated with decision making and to specify tolerable limits on making a decision error. A decision error occurs when the data lead the decision makers to take an action when one is not necessary, or to not take an action when one is warranted.

For estimation statements, the inherent variability and uncertainty in collected data means there will be uncertainty associated with the estimate. The extent of uncertainty will be reported with the actual estimate. By designing the data collection process appropriately, the level of uncertainty in parameter estimates can be controlled to achieve specified criteria. The criteria could be set to control the magnitude of the standard error of the estimate or the width of an interval estimate. Both of these depend on the inherent variability of the data and the amount of data collected. Provided samples are collected and analyzed using sound techniques; only the amount of data collected can be controlled. For new sites with radiological contamination, the surface will be scanned. For new sites that are not to be scanned, the criterion will be the width of an upper one-sided confidence interval. For a confidence interval, the confidence level also must be specified and is related to the Type I error, described below.

Decision statements, which are based on measurement data that provide only an estimate of the true state of the media being characterized, could also be in error. Tolerable limits on the probability of making a decision error can sometimes be defined. Data quality objective decisions are based on two hypotheses; the baseline condition is referred to as the null hypothesis $\left(\mathrm{H}_{0}\right)$ and a specified alternative condition is the alternative hypothesis $\left(\mathrm{H}_{\mathrm{A}}\right)$. The null hypothesis is presumed to be true in the absence of strong evidence to the contrary, which allows decision-makers to guard against making the decision error having the most undesirable consequences.

A decision error occurs when the decision-maker rejects the null hypothesis when it is true, or fails to reject the null hypothesis when it is false. These two types of decision errors are classified as false positive and false negative decision errors, respectively. False positive and false negative errors are defined in accordance with the definition of the null and alternative hypothesis. For example, a decision-maker presumes a certain waste is hazardous (i.e., the null hypothesis is "the waste is hazardous"). If the data cause the decision-maker to conclude that the waste is not hazardous when it truly is hazardous, then the decision-maker would make a false positive decision error. Statisticians refer to this error as a Type I error. The measure of the size of this error is called alpha $(\alpha)$, which is the level of significance or the size of the critical region. If, however, the data cause the decision-maker to 
conclude that the waste is hazardous when, in fact, it is not, then the decision-maker would make a false negative decision error. Statisticians refer to this error as a Type II error. The measure of the size of this error is called beta $(\beta)$ and is also known as the complement of the power of a hypothesis test.

The possibility of decision error cannot be eliminated but it can be minimized, which is accomplished by controlling the total study error. Methods for controlling total study error include collecting a large number of samples (to control sampling design error), analyzing individual samples several times, or using more precise analytical methods (to control measurement error). The chosen method for reducing decision errors depends on where the greatest component of total study error exists in the data set and the ease in reducing the error contributed by those data components. The amount of effort expended on controlling decision error is directly proportional to the consequences of making an error. The decision errors can be estimated or specified if the decision involves a statistical hypothesis test, but not all decisions are based on statistical hypothesis tests.

The decision error that has the more severe consequences as the true concentrations of the parameters of interest approach the action level must be specified, as it is the basis for establishing the null hypothesis. This decision error is used because as the parameters approach the action level, the data are much more likely to lead to an incorrect decision than when the parameters are far above or below the action level. For regulatory compliance, human health, or environmental risk issues, the decision error that has the most adverse consequences will be favored as the null hypothesis. In statistical hypothesis testing, the data must conclusively demonstrate that the null hypothesis is false. Therefore, setting the null hypothesis to the condition that exists when the more adverse decision error occurs, guards against making that decision error by placing the burden of proof on demonstrating that the most adverse consequences will not be likely to occur.

A range of possible parameter values must be specified where the consequences of decision errors are relatively minor. This range of values is referred to as the "gray region," which is bounded on one side by the action level and on the other side by the parameter value where making a false negative decision error begins to be significant (U). It is necessary to specify the gray region because the variability in the sample population and unavoidable imprecision in the measurement system combine to produce variability in the data such that a decision may be "too close to call" when the true parameter value is very close to the action level. In statistics, this interval is called the "minimum detectable difference" and is expressed as delta $(\Delta)$. The width of this gray region is critical in calculating the number of samples needed to satisfy the data quality objectives. A narrow gray region indicates a desire to detect conclusively the condition when the true parameter value is close to the action level.

The final activity required in specifying the tolerable limits on decision error is to assign values to the gray region that reflect the probability of decision errors occurring. These probability values are the decision-maker's tolerable limits for making an incorrect decision. These values are determined by selecting a possible true value for the parameter of interest, then choosing a probability limit based on an evaluation of the seriousness of the potential consequences of making a decision error if the true parameter value is located at that point.

The first goal is to estimate the nature and extent of contamination at a new site. For sites that will be scanned, refer to DS1. For sites that will be sampled (instead of being scanned), the confidence level will be set at $95 \%$ (which corresponds to a Type I error of 5\%). The width of an upper one-sided confidence interval is the upper confidence limit minus the sample mean, and will be specified as one-half the sample standard deviation.

The second goal/decision is to determine if the excavation has removed all soils that exceed remediation goals. The null hypothesis is that the excavation has not removed all soil that exceeds COC 
remediation goals and the alternative hypothesis is that the excavation has removed all soil that exceeds COC remediation goals. This will be accomplished through constant real-time spectroscopy during excavation. If real-time spectroscopy results exceed remediation goals, excavation continues in the region. If real-time spectroscopy results do not exceed remediation goals, then excavation is halted in the region. The decision errors are (1) to conclude that COCs are below remediation goals when, in fact, COCs exceed remediation goals, and (2) to conclude that COCs exceed remediation goals when, in fact, COCs are below remediation goals. The consequence of making the (1) error is contaminated soil may be left unremediated. This might in turn lead to confirmatory sample results exceeding remediation goals and cause further excavation at a later time. The consequence of making the (2) error is the cost of excess excavation. No statistical hypothesis test is performed for this decision statement, so the probabilities for decision errors cannot be specified. The probability of making these errors depends on the uncertainty in the scanning instrument and the intensity of the real-time spectroscopy. To ensure lower probabilities of errors, the real-time spectroscopy will be performed carefully and the action level associated with the spectroscopy instrument will be set at $15 \%$ below the remediation goal.

The third decision is to confirm that the remaining (to $10 \mathrm{ft}$ bgs) soil COCs do not exceed remediation goals. The null hypothesis is that the real-time spectroscopy results or the true mean concentration exceeds the remediation goal. The alternative hypothesis is that the real-time spectroscopy results or the true mean concentration does not exceed the remediation goal. The decision errors are (1) to conclude that the remaining soils do not exceed remediation goals when, in fact, at least one COC does exceed remediation goals, and (2) to conclude that the remaining soils exceed remediation goals when, in fact, no COCs exceed remediation goals. The consequence of making the (1) error is contaminated soil may be left unremediated. The consequence of making the (2) error is cost of further investigation and possible unnecessary remedial action. For sites that require sampling, this decision is based on the $95 \%$ upper confidence limit for the COCs. The probability of a Type 1 error is set at 0.05 (corresponding to a 95\% upper confidence limit) and probability of a Type II error at 0.20 (when the true mean concentration is equal to $U$ ). The gray region will be bounded on one side by the constituent-specific action level (i.e., remediation goal) and on the other side by a value that is $70 \%$ of the constituent-specific action level. For sites that do not require sampling, the probability of making these errors depends on the uncertainty in the scanning instrument and the intensity of the real-time spectroscopy. To ensure lower probabilities of errors, the real-time spectroscopy will be performed carefully and the action level associated with the spectroscopy instrument will be set at $15 \%$ below the remediation goal.

\subsubsection{Develop the Plan for Obtaining Data}

The objective of this step is to develop a resource-effective design for collecting and measuring samples or for generating other types of information needed to address the problem statement. The activities required to optimize the design include:

1. Review the outputs of the data quality objective steps and existing characterization data

2. Develop general data collection design alternatives (such as direct push probes and real-time spectroscopy)

3. Formulate a mathematical expression needed to solve the design problem for the data collection design alternatives

4. Select the optimal number of samples to satisfy the data quality objectives for each data collection design alternative

5. Select the most resource-effective data collection design that satisfies all the data quality objectives. 
A review of the existing environmental data was performed for each site and deficiencies in the existing data were identified. First, the new sites (i.e., CPP-124) have no existing data to determine the nature, location, and extent of the contamination. Definitive sample data will be required to resolve the data deficiency. The majority of the Group 3 Phase II sites have existing data that will be used to begin the remedial action of each site with the use of real-time spectroscopy data to asses the extent of contamination. Finally, the remediation of each site will be complete based on the absence of contamination as confirmed through real-time analysis or in the case of CPP-93 through the collection of definitive sampling data. These sampling design approaches form the basis for the sampling and analysis designs presented in the following sections. The sampling design for each Phase II site is discussed relative to the estimation and decision statements developed in Section 3.1.2. A summary of the number of samples and data required to resolve each statement is identified in Table 4-1.

\section{Estimation Statement 1}

For new sites or other OU 3-13 sites that are suspected to contain radiological contamination, a scan will be performed. For new sites or other OU 3-13 sites that are suspected to contain non-radiological contamination, sampling and analysis will be performed. The analysis results will be used to calculate the $95 \%$ upper confidence limit. As specified above, the confidence interval half-width should be no more than one-half the standard deviation. The $95 \%$ upper confidence limit will be calculated assuming the data follow a normal or lognormal distribution. The Shapiro-Wilk test will be performed to determine if natural log transformation is necessary. The $95 \%$ upper confidence limit will be calculated as follows:

$\bar{x}+1.645 \times s / \sqrt{n}$,

where
$\bar{x} \quad=\quad$ sample mean
$1.645=$ 95th percentile of the standard normal distribution $(\mathrm{z})$
$s \quad=\quad$ sample standard deviation
$n=$ number of samples.

The half-width of the interval is then set to $\mathrm{s} / 2$,

$(\overline{\mathrm{x}}+1.645 \times \mathrm{s} / \sqrt{\mathrm{n}})-\overline{\mathrm{x}}=\mathrm{s} / 2$

which reduces to

$\mathrm{n}=(2 \times 1.645)^{2}=10.8 \uparrow 11$

For new sites with non-radiological contamination for which sampling and analysis is necessary, 11 samples will be collected.

For sites where the release location is known, sampling will be partially biased toward the release location while retaining some spatial separation and a random component. For example, if the release is 
along a pipe, then samples will be collected as close to the pipe as possible with spatial separation designated by intervals covering the suspected contamination boundary and a random point chosen within the intervals.

For sites where the release location is not known, the design will be a systematic square grid sample with a random start. A systematic sample design, versus a purely random design, provides even coverage over the area of interest and better ability to determine if contamination exists. The random start provides a chance for all areas to be sampled and allows for inference from the samples to the whole site. The suspected contamination area will be divided into equal square areas (allowing for irregularities in the site boundary as well as surface and subsurface structures) to identify a minimum of 11 sample locations (including vertical). A random location will be selected in one grid and that location within the grid will be transcribed onto the other grids horizontally. The number of surface grids is determined from dividing 11 by the number of depth samples to be taken.

These sample locations are on a grid at ground surface with a sample being collected at the surface (or historical surface, if backfill has been placed on top) and one or two additional samples collected at 5 -ft increments down to $10 \mathrm{ft}$ bgs using a direct push probe or other means.

\section{Decision Statement 1}

As stated in Step 6, Decision Error Limits, there is no hypothesis test performed as part of this decision statement, so decision errors are not easily defined. The decision error that would fail to continue excavating contaminated soil is the more severe. Thus, every effort will be made to reduce or eliminate spectroscopy interferences.

Determining the extent of radionuclide contamination in Group 3 Phase II sites will be determined using real-time soil spectroscopy instrumentation. The design criteria were developed using guidance provided in the Multi-Agency Radiation Survey and Site Investigation Manual (MARSSIM) to demonstrate that these sites are remediated to the OU 3-13 ROD remediation requirements. MARSSIM recognizes and embraces the value of real-time measurement systems. MARSSIM's focus is on final status spectroscopy and site closure. It also provides an overall framework for initial site characterization and real-time decision making during site excavation and confirmation analysis.

Real-time soil spectroscopy will be used for contamination extent determinations during excavations and for final status spectroscopy or confirmation analysis for Phase II sites. MARSSIM manages decision uncertainty in the remediation process through the use of statistically designed sampling programs and the application of non-parametric statistical analysis techniques. MARSSIM provides for the use of real-time spectroscopy as an average contamination result and an elevated measurement comparison (or hot spot) spectroscopy methods. For Group 3 sites, the performance-based goal for site remediation is the OU 3-13 ROD-established remediation goals.

\section{Decision Statement 2}

For those sites that are remediated, either real-time spectroscopy or confirmation sampling and analysis is required to ensure that the $\mathrm{COC}$ concentrations are below remediation goals. The discussion from Decision Statement 1 applies to sites that do not require sampling. For sites that are sampled, the 95\% upper confidence limit will be calculated assuming the data follow a normal distribution. This assumption will be tested using the Shapiro-Wilk test. Data will be transformed if necessary. If log-transformed data are normal, then the $95 \%$ upper confidence limit from the transformed data will be compared to the log-transformed remediation goal. A systematic random sampling approach will be used to determine sampling locations. 
When using a simple or systematic random sampling approach, there are commonly accepted mathematical expressions to solve design problems for these data collection design alternatives (EPA 1989). The formula for determining the number of samples to be collected is selected based on the hypothesis test and data collection design. In this case, the hypothesis test will be of the null hypothesis that the concentration exceeds the action level versus the alternative hypothesis that the concentration is below the action level. The formula provided adjusts for using the standard normal $\mathrm{Z}$ instead of iteratively using the $t$ distribution to determine sample size. Using this hypothesis test, the formula shown in Equation (3-1) is used for computing the number of samples required to be collected for a simple random sampling approach:

$$
n=\frac{\hat{\sigma}^{2}\left(\mathrm{Z}_{1-\beta}+\mathrm{Z}_{1-\alpha}\right)^{2}}{\Delta^{2}}+(.5) \mathrm{Z}_{1-\alpha}{ }^{2}
$$

where

$$
\begin{aligned}
& \hat{\sigma}^{2}=\text { estimated variance in measurements } \\
& n=\text { number of samples required } \\
& \mathrm{Z}_{\mathrm{p}}=\text { the } \mathrm{p}^{\text {th }} \text { percentile of the standard normal distribution (from statistical tables) } \\
& \Delta \quad=\quad \text { action level - } \mathrm{U} \text { (the minimum detectable difference) } \\
& \mathrm{U} \quad=\quad \text { parameter value where making a false negative decision error begins to be significant. }
\end{aligned}
$$

Data from Background Dose Equivalent Rates and Surficial Soil Metal and Radionuclide Concentrations for the Idaho National Engineering Laboratory (INEL 1996) were used to determine appropriate coefficients of variance for background soils at the INL. The coefficient of variance is used because it is assumed to be independent of the mean concentration, which is not the case in general for the variance. The coefficients of variance for our contaminants of concern are $46 \%$ for Cs- $137,38 \%$ for Sr-90, and $37 \%$ for mercury. The maximum coefficient of variance of $46 \%$ was used to determine sample size. A gray area width equal to $30 \%$ of the action level was used because the maximum background concentrations are less than 5\% of the remediation goals (INEL 1996). All background concentration sample results for the three contaminants of concern are less than $1 \mathrm{pCi} / \mathrm{g}$ or $\mathrm{mg} / \mathrm{g}$, while the remediation goals are $23 \mathrm{pCi} / \mathrm{g}, 223 \mathrm{pCi} / \mathrm{g}$, and $23 \mathrm{mg} / \mathrm{g}$ for Cs-137, Sr-90, and mercury, respectively. Thus, post-remediation levels should be much less than $70 \%$ of the action level, and the decision criteria should be met without excessive sampling. Using a width of the gray area that is $30 \%$ of the action level results in $U$ being defined as $70 \%$ of the action level. To calculate the sample size, the lower value of the gray area, $U$, is assumed to be true. Thus, the variance in Equation 3-1 is based on the coefficient of variance as $46 \%$ of $U$. Because $U$ is $70 \%$ of action level, the variance is estimated as $(0.46)(0.7)$ (action level) $=$ $32 \%$ action level. Assuming an acceptable chance of false positive decision error $(\alpha)$ to be $5 \%$ when the true concentration is equal to the action level, and an acceptable chance of false negative decision error $(\beta)$ to be $20 \%$ when the true concentration is equal to $U$, the following equation shows the solution for $n$ (number of samples required) using the project-specific variables. The values for $\alpha$ and $\beta$ were specified in Step 6 of the data quality objectives (Specification of Decision Error Limits). The sample size is rounded up to the next largest integer (see Equation 3-2).

$$
\mathrm{n}=\frac{32^{2}(0.842+1.645)^{2}}{30^{2}}+(0.5)(1.645)^{2}=7.5 \uparrow 8
$$


A minimum of eight samples will be collected from the excavation areas at each of the soil remediation sites that require confirmation sampling. See Figure 3-1 for approximate number of samples per grid. If the FSP results are in the gray area, then further sampling may ensue. Further sampling to support a gray area decision within $80 \%$ of the action level would amount to 11 additional samples being collected. If these additional samples do not refute the null hypothesis that the soil concentrations exceed the action level, then additional remediation will be performed. If these additional samples support the alternative hypothesis, then the site will be released.

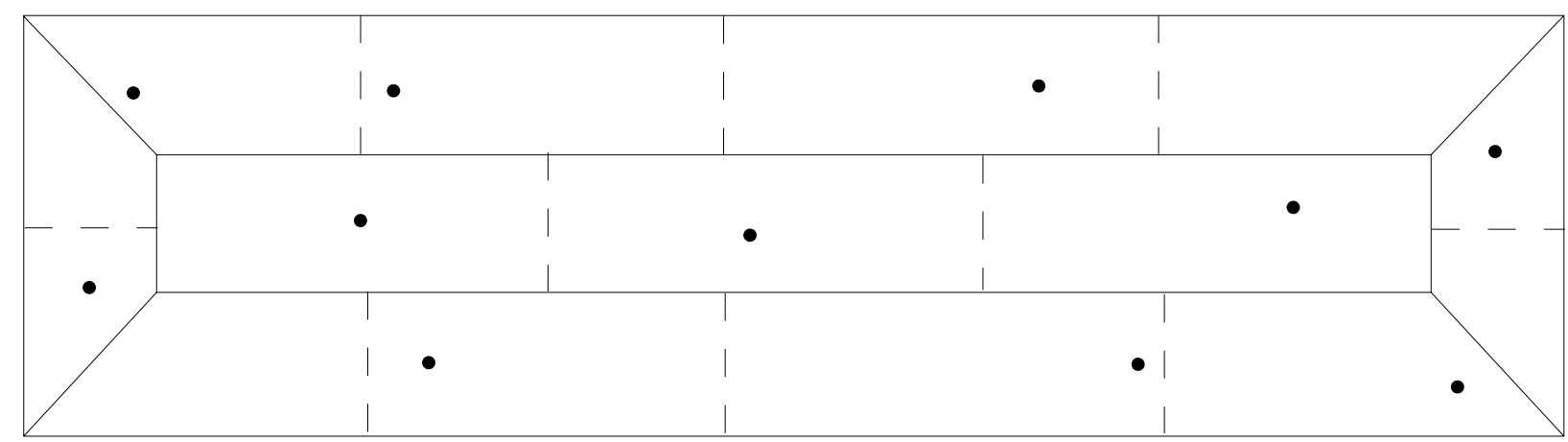

Figure 3-1. Hypothetical site with 10-ft excavation sloped to the excavation boundary. The area was divided into area grids and one random sample location placed in each grid.

\subsection{Measurement Performance Criteria}

The measurement quality objectives specify that measurements will meet or surpass the minimum requirements for data quality indicators established in the QAPjP (DOE-ID 2004a). As a result, the technical and statistical quality of these measurements must be properly documented. Precision, accuracy, completeness, and sensitivity (method detection limits) must be specified for physical/chemical measurements. Additional analytical requirements are described qualitatively in terms of representativeness and comparability. These measurement quality objectives are described in the following sections. Table 3-1 presents the analytical performance requirements for laboratory samples.

Table 3-1. Analytical performance requirements.

\begin{tabular}{|c|c|c|c|c|c|}
\hline Analyte List & $\begin{array}{l}\text { Survey/ } \\
\text { Analytical } \\
\text { Method }\end{array}$ & $\begin{array}{l}\text { Preliminary } \\
\text { Action Level }\end{array}$ & $\begin{array}{c}\text { Practical } \\
\text { Quantitation } \\
\text { Limit }\end{array}$ & $\begin{array}{c}\text { Precision } \\
\text { Requirement }\end{array}$ & $\begin{array}{c}\text { Accuracy } \\
\text { Requirement }\end{array}$ \\
\hline \multirow{3}{*}{$\begin{array}{l}\text { Gamma emitters } \\
\text { (Cs-137, Eu-152, } \\
\text { Eu-154) }\end{array}$} & \multirow{3}{*}{$\begin{array}{l}\text { Gamma } \\
\text { spectroscopy }\end{array}$} & Cs- $137 \geq 23 \mathrm{pCi} / \mathrm{g}$ & \multirow[t]{3}{*}{$0.1 \mathrm{pCi} / \mathrm{g}$} & \multirow[t]{3}{*}{ $\pm 20 \%$} & \multirow[t]{3}{*}{$80-120$} \\
\hline & & Eu-152 $\geq 270 \mathrm{pCi} / \mathrm{g}$ & & & \\
\hline & & $\mathrm{Eu}-154 \geq 5200 \mathrm{pCi} / \mathrm{g}$ & & & \\
\hline \multirow{4}{*}{$\begin{array}{l}\text { Alpha emitters } \\
\text { (Am-241, } \\
\text { Pu-238, } \\
-239 / 240)\end{array}$} & \multirow{4}{*}{$\begin{array}{l}\text { Alpha/Gamma } \\
\text { spectroscopy }\end{array}$} & Am-241 $\geq 290 \mathrm{pCi} / \mathrm{g}$ & \multirow{4}{*}{$\begin{array}{l}\text { QAPjP } \\
\text { (DOE-ID } \\
\text { 2004a) }\end{array}$} & \multirow[t]{4}{*}{ $\pm 30 \%$} & \multirow[t]{4}{*}{$70-130$} \\
\hline & & $\mathrm{Pu}-238 \geq 670 \mathrm{pCi} / \mathrm{g}$ & & & \\
\hline & & $\mathrm{Pu}-239 / 240 \geq 250 \mathrm{pCi} / \mathrm{g}$ & & & \\
\hline & & 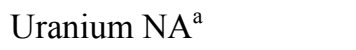 & & & \\
\hline
\end{tabular}


Table 3-1. (continued).

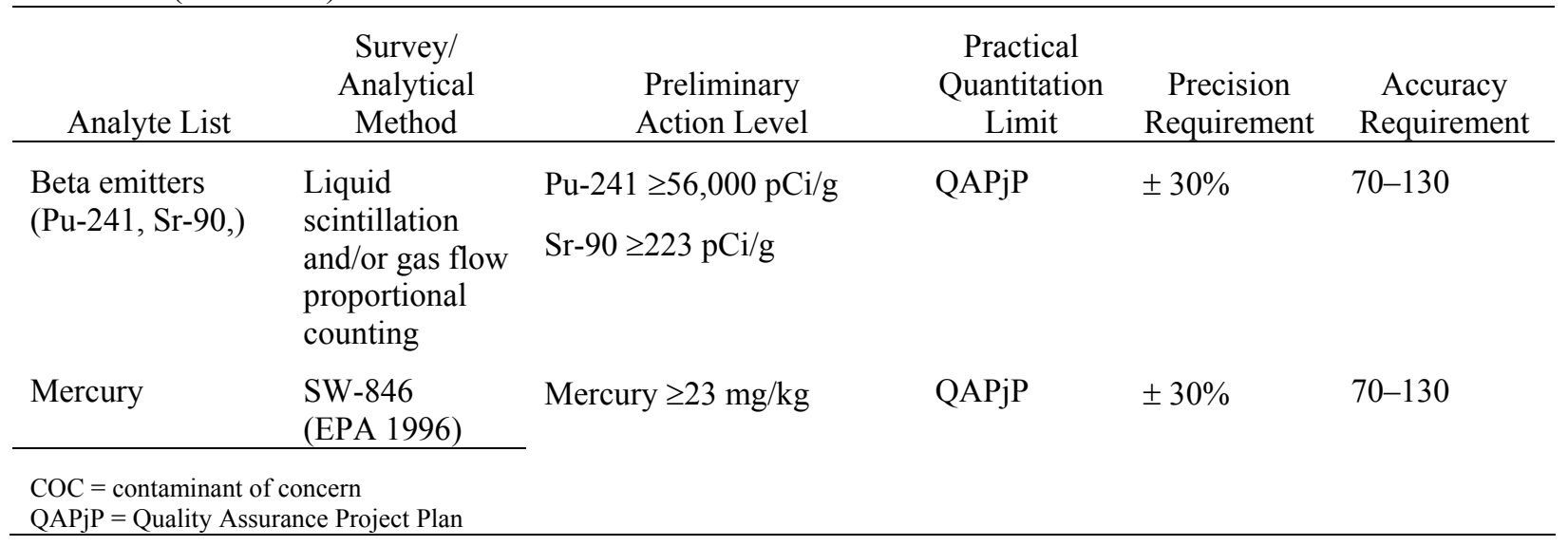

\subsubsection{Precision}

Precision is a measure of agreement or reproducibility among individual measurements for the same property under the same conditions. Precision is expressed as relative percent difference, which is defined, and shown in Equation (3-3), as the absolute value of the difference divided by the mean, then expressed as a percentage.

$$
\mathrm{RPD}=\frac{|(\mathrm{MS}-\mathrm{MSD})|}{(\mathrm{MS}+\mathrm{MSD}) / 2} \times 100
$$

where

$$
\begin{aligned}
& R P D=\text { relative percent difference } \\
& M S=\text { measured concentration of parameter in matrix spike sample } \\
& M S D=\text { measured concentration of parameter in matrix spike duplicate sample. }
\end{aligned}
$$

The analytical laboratory will report the precision of their measurements of the matrix spike and matrix spike duplicate analyses conducted for organic analyses. For all radiochemical and some inorganic measurements, precision will be calculated using duplicate measurements of the same sample. Replicate measurements are used for metals determination after duplicate sample preparation, during instrumental analysis, and for mercury determinations post-digestion. Radiochemical measurements will use separate sample splits for solid samples to determine measurement precision.

Acceptable laboratory precision will be determined by method-specific criteria outlined in SW-846, Test Methods for Evaluating Solid Waste, Physical/Chemical Methods (EPA 1996), for total metals and each requested organic analysis. Acceptable radiochemical measurement precision will be determined using the guidance outlined in the Statement of Work ER-SOW-394, "Idaho National Engineering and Environmental Laboratory Sample and Analysis Management Statement of Work for Analytical Services."

\subsubsection{Accuracy}

Accuracy is the relative agreement or non-agreement between a measured value and an accepted reference value. Accuracy reflects the measurement error associated with a measurement and is 
determined by assessing actual measurements in the sample matrix during the analysis of matrix spike samples. Accuracy is assessed by means of determining analyte recovery from matrix spikes, samples, or laboratory reference samples and is expressed as a percent recovery $(\% \mathrm{R})$. It is defined as the measured value divided by the true value expressed as a percent, as shown in Equation (3-4).

$\% \mathrm{R} \frac{\mathrm{C}_{\mathrm{ss}}-\mathrm{C}_{\mathrm{us}}}{\mathrm{C}_{\mathrm{as}}} \times 100$

where

$$
\begin{aligned}
& \% R=\text { percent recovery } \\
& C_{s s}=\text { measured analyte concentration in spiked sample } \\
& C_{u s}=\begin{array}{l}
\text { measured analyte concentration in non-spiked samples (or zero for laboratory } \\
\text { reference samples) }
\end{array} \\
& C_{a s}=\text { calculated or certified analyte concentration added to sample. }
\end{aligned}
$$

For inorganic analyses, the analytical laboratory will represent the accuracy of their measurements in the sample matrix as the results of the matrix spike data. Acceptable laboratory accuracy will be determined by assessing the results against method-specific criteria outlined in SW-846 (EPA 1996) for total metals and each requested organic analysis. Radiochemical method accuracy will be determined by assessing the results against the criteria outlined in ER-SOW-394. During the data quality assessment process, accuracy of the environmental measurements (in the form of bias, may be indicated by the measure discussed above) will be assessed to determine if there are any impacts on data use due to the accuracy of the data.

\subsubsection{Representativeness}

Representativeness is a measure of the degree to which data accurately and precisely represent a characteristic of a population parameter at a sampling point, a process condition, or an environmental condition. Representativeness is a qualitative term that should be evaluated to determine whether in situ and other measurements are made and physical samples are collected in such a manner that the resulting data appropriately reflect population parameters of interest in the media and phenomenon measured or studied.

The sampling design discussed in this plan is the basis for obtaining data that are representative of the Group 3, Other Surface Soils, sites. The project manager and other project personnel will make a final determination of representativeness for the initial data set, following the return of the chemical and radiological analytical data.

\subsubsection{Completeness}

Completeness is the measure of the amount of valid analytical data obtained compared to the total number of data points planned. Valid analytical data are those generated when analytical systems and the resulting analytical data meet all data quality assessment objectives outlined for the project (i.e., all calibration verification interference and other checks not affected by the sample matrix meet acceptance criteria). It is important to understand that data that are flagged during the data validation process are not necessarily invalid data. Part of the data quality assessment process is the review of flagged data to determine whether the validation flags impact the intended use of the data. Therefore, the definition of "valid data" in the context of calculating completeness is "data that are acceptable for their 
intended purpose." Completeness of the reported data (expressed as a percentage) is calculated as shown in Equation (3-5).

$$
\mathrm{C}(\%)=\mathrm{M}_{\mathrm{v}} / \mathrm{Mt}_{\mathrm{t}} \times 100
$$

where

$$
\begin{aligned}
& C(\%)=\text { completeness } \\
& M_{v}=\text { number of measurements determined to be valid per analyte } \\
& M_{t}=\text { total number of measurements performed per analyte. }
\end{aligned}
$$

All data obtained from this project should meet the quality requirements and reporting protocols unless irregularities in the matrix (also known as matrix effects) impede contaminant recovery, or a broken, spilled container results in a loss of sample materials. The completeness goal for the project is $90 \%$, which is sufficient to obtain valid data to satisfy the data quality objective specifications.

\subsubsection{Comparability}

Comparability is the degree to which one data set can be compared to another obtained from the same population using similar techniques for data gathering. Comparability will be achieved through the use of consistent sampling procedures, experienced sampling personnel, the same analytical method for like parameters using Environmental Protection Agency and ICP specified protocols, standard field and laboratory documentation, and traceable laboratory standards.

\subsubsection{Sensitivity}

The laboratory will use guidance found in SW-846 (EPA 1996) or the Code of Federal Regulations 40 CFR 136, Appendix B, to aid in appropriately determining method detection limits for organic and inorganic analytical methods and the requirements of ER-SOW-394 for setting minimum detectable activities for radiochemical measurements. The method detection limits and minimum detectable activities are defined as the minimum concentration or activity of a substance that can be reliably measured and reported by a particular analytical method. Matrix effects, sample size, radiation levels, or other analytical interferences may increase method detection limits or minimum detectable activities. The effects of these conditions on the laboratory's method detection limits or minimum detectable activities, if determinable, will be documented.

Chemical methods for all total metals and other analyses typically use the standard deviation of replicate measurements of standards multiplied by a factor specified by the method or laboratory SOW to determine minimum method detection limits. Estimated detection limits are provided in each of the appropriate analytical methods for chemical determinations and serve as a guide for purposes of this FSP. The laboratory will use standard radiochemistry and chemical analysis practices to ensure the method detection limits approach those prescribed in the analytical laboratory SOW. Any significant deviations will be identified in the reported data.

Methods for the determination of radionuclides and applicable minimum detectable activities will be as defined in ER-SOW-394 or as defined in the project-specific analytical laboratory SOW. The laboratory will attempt to keep minimum detectable activities as low as possible, given the constraints of the sample matrix and any remote sample handling operations required to ensure the safety of laboratory personnel. 
3.2.6.1 Laboratory Sensitivity. The laboratory analysts will follow the SW-846 (EPA 1996) and ER-SOW-394 methods as closely as possible to ensure the data are compliant with the requirements of the project. A smaller sample size may introduce a dilution effect, thereby elevating the detection level for a given sample or analysis. In the event that sample volume (or mass) prohibits the use of SW-846 (EPA 1996) protocols, the laboratory will make a good faith effort to assign methods that will provide acceptable, usable data and document all method deviations in the case narrative provided with the data package. Table 3-2 describes the analytical methods and detection limits for each contaminant of potential concern.

3.2.6.2 Field Sensitivity. Field real-time spectroscopy analysts will follow established procedures for real-time spectroscopy as closely as possible to ensure the data are compliant with the requirements of the project. The field analyst will make a good faith effort to employ procedures that will provide acceptable, usable data and document all method deviations in the case narrative provided with the data results. Table 3-3 describes the instrumentation and detection limits for each COC analyzed using filed instrumentation.

\subsection{Data Quality}

In addition to primary project samples, Quality Assurance/Quality Control (QA/QC) samples will be collected during characterization sampling and confirmation sampling (CPP-124, and CPP-93 to establish the quantitative and qualitative criteria necessary to support the remedial action decision process and to describe the acceptability of the data by providing information both comparable to and representative of actual field conditions. To determine field accuracy, QA/QC samples consisting of field blanks and equipment rinsate blanks will be used. QA/QC duplicate samples will be used to measure field and laboratory precision. The QA/QC sample results will be evaluated as outlined in the QAPjP (DOE-ID 2004a). Table 3-4 provides an overview of QA/QC for laboratory sample analysis for this sampling effort.

Table 3-2. Laboratory analytical methods and detection limits for each contaminant of concern.

\begin{tabular}{|c|c|c|}
\hline Constituent & Analytical Method & Solids Detection Limits \\
\hline Mercury & $\begin{array}{l}\text { Environmental Protection Agency } \\
\text { SW-846 Method } 7473\end{array}$ & $0.5 \mathrm{ug} / \mathrm{kg}$ \\
\hline Plutonium-241 & Liquid scintillation counting & $1 \mathrm{pCi} / \mathrm{g}$ \\
\hline Plutonium isotopes & Alpha spectrometry & $0.05 \mathrm{pCi} / \mathrm{g}$ \\
\hline Americium-241 & Alpha spectrometry & $0.05 \mathrm{pCi} / \mathrm{g}$ \\
\hline $\begin{array}{l}\text { Uranium-234, }-235 \text {, } \\
\text { and }-238\end{array}$ & Alpha spectrometry & $0.05 \mathrm{pCi} / \mathrm{g}$ \\
\hline Cesium-137 & Gamma spectrometry & $\begin{array}{l}\text { Detection limit is indicated in the } \\
\text { analytical method for each constituent }\end{array}$ \\
\hline Europium-152 & Gamma spectrometry & $\begin{array}{l}\text { Detection limit is indicated in the } \\
\text { analytical method for each constituent }\end{array}$ \\
\hline Europium-154 & Gamma spectrometry & $\begin{array}{l}\text { Detection limit is indicated in the } \\
\text { analytical method for each constituent }\end{array}$ \\
\hline
\end{tabular}


Table 3-3. Field real-time spectroscopy instrumentation and detection limits for each contaminant of concern.

\begin{tabular}{lll}
\hline \multicolumn{1}{c}{ Constituent } & \multicolumn{1}{c}{ Instrumentation } & \multicolumn{1}{c}{ Solids Detection Limits } \\
\hline Mercury & $\begin{array}{l}\text { Jerome Mercury Vapor and Lumex } \\
\text { Mercury Analyzer }\end{array}$ & $0.2 \mathrm{mg} / \mathrm{kg}$ \\
Cesium-137 & $\begin{array}{l}\text { High-Purity Germanium (HPGe), } \\
\text { Sodium Iodide or Lanthanum Halide } \\
\text { Europium-152 }\end{array}$ & $2 \mathrm{pCi} / \mathrm{g}$ \\
& HPGe, NaI or LaX & $\begin{array}{l}\text { Detection limit is indicated in the } \\
\text { analytical method for each } \\
\text { constituent }\end{array}$ \\
Europium-154 & HPGe, NaI or LaX & $\begin{array}{l}\text { Detection limit is indicated in the } \\
\text { analytical method for each } \\
\text { constituent }\end{array}$ \\
& & $50 \mathrm{pCi} / \mathrm{g}$ \\
\hline
\end{tabular}

Table 3-4. Quality assurance/quality control samples.

\begin{tabular}{ll}
\hline \multicolumn{1}{c}{ QA/QC Sample Type } & \multicolumn{1}{c}{ Comment } \\
\hline Duplicate & $\begin{array}{l}\text { Field duplicates will be collected at a frequency of } 1 / 20 \text { samples, } \\
\text { or } 1 / \text { day/matrix, whichever is less. }\end{array}$ \\
Field blanks & $\begin{array}{l}\text { Field blanks are only recommended for subsurface soils }(>6 \text { in.) } \\
\text { collected for radionuclide analysis. Field blanks will be collected } \\
\text { at a frequency of } 1 / 20 \text { samples, or } 1 / \text { day, whichever is less. }\end{array}$ \\
Trip blanks & $\begin{array}{l}\text { Trip blanks are not recommended for soil samples; thus, they will } \\
\text { not be collected. }\end{array}$ \\
Equipment rinsate & $\begin{array}{l}\text { Equipment rinsate samples will be collected at a frequency of } 1 / 20 \\
\text { samples, or } 1 / \text { day/matrix, whichever is less. Equipment blanks are } \\
\text { not required if dedicated or disposable equipment is used. }\end{array}$ \\
\hline
\end{tabular}

\subsection{Data Validation}

Data will be acquired, processed, and controlled prior to input to the Integrated Environmental Data Management System, per ICP internal procedures. For the samples submitted to the analytical laboratory, all data will be validated to Level B, in accordance with the QAPjP (DOE-ID 2004a).

A data limitation and validation report, including copies of chain-of-custody forms, sample results, and validation flags, will be generated for each sample delivery group. All data limitation and validation reports associated with a site will be transmitted to the Environmental Protection Agency and Idaho Department of Environmental Quality within 120 days from the last day of sample collection. All definitive data will be uploaded to the Integrated Environmental Data Management System.

The Sample and Analysis Management group will ensure the data are validated to Level B, as specified. The analytical method data validation will be conducted in accordance with current ICP sample and analysis management data validation procedures. Validated data are entered into the Integrated Environmental Data Management System. 


\section{SAMPLE COLLECTION, ANALYSIS AND DATA MANAGEMENT}

This section outlines the specific sample collection strategies, field analysis, and data management requirements for the Group 3 Phase II soil remedial action. These sampling and analysis requirements will guide the collection of representative samples as specified in the data quality objectives (Section 3.1) and the remedial action objectives defined in the Group 3 Phase II Remedial Design/Remedial Action Work Plan (DOE-ID 2006a).

\subsection{Soil Sample Collection and Analysis Strategies}

The following subsections describe the Group 3 Phase II site-specific samples collection strategy and requirements discussed in the Group 3 Phase II Remedial Design/Remedial Action Work Plan. Table 4-1 summarizes the confirmation sampling and analysis requirements for the Group 3 Phase II soil sites.

\subsubsection{Pre Sampling Meeting}

Sampling procedures will be discussed prior to each sampling event in a pre-sampling meeting. The meeting discussion will include, but is not limited to, sampling activities, responsibilities of team members, health and safety issues, and waste management. Any deviations from the sampling strategy presented in Section 6 of this FSP will be documented in the field-sampling logbook.

Samplers prepare for the sampling activities in accordance with Management Control Procedure (MCP) -9228, "Managing Nonhazardous Samples," or MCP-1394, "Managing Hazardous Samples," as appropriate, and participate in applicable pre-job briefings conducted in accordance with MCP-3003, "Performing Pre-Job Briefings and Documenting Feedback."

\subsubsection{Characterization Sampling and Analysis (PSQ-1)}

Characterization samples will be collected from site CPP-124 and other soil sites that may be included in the Group 3 Phase II Remedial Design/Remedial Action Work Plan for remedial action. Typically, these sites have limited or no existing characterization data; therefore, sampling and analysis is required to determine the nature and extent of soil contamination. Following an evaluation of the validated data, a CERCLA action determination and recommendation will be made for each site.

Surface hot spots may be located using real-time spectroscopy instrumentation (see Section 4.1.3.1), and subsurface contamination (where Cs-137 is a suspected constituent) may be identified using direct push probe gamma logging to a maximum depth of $10 \mathrm{ft}$ bgs. Following the identification of the soil contamination area, direct push probe sampling equipment may be used to collect grab samples if subsurface sampling is required. The number of samples to be collected will depend on the contamination area as defined in the data quality objectives.

4.1.2.1 CPP-124 - Characterization Sampling and Analysis. CPP-24 was a pipe leak located east of CPP-601. The piping is approximately $5 \mathrm{ft}$ below grade. Twelve samples will be collected for analysis. These samples will be collected based on a four grid system over the pipe location. Three vertical samples will be collected from each push probe location on the grid. These samples will be collected at or below the elevation of the pipe in question. No samples will be collected at the surface. The samples will be collected at even intervals beginning at approximately $5 \mathrm{ft}$ bgs extending down to $10 \mathrm{ft}$ bgs. These samples will be grab samples collected from a push probe and will be analyzed for radiolonuclides, organics, and metals. Figure 4-1 shows the sampling grid and potential sampling/probe locations for CPP-124. 


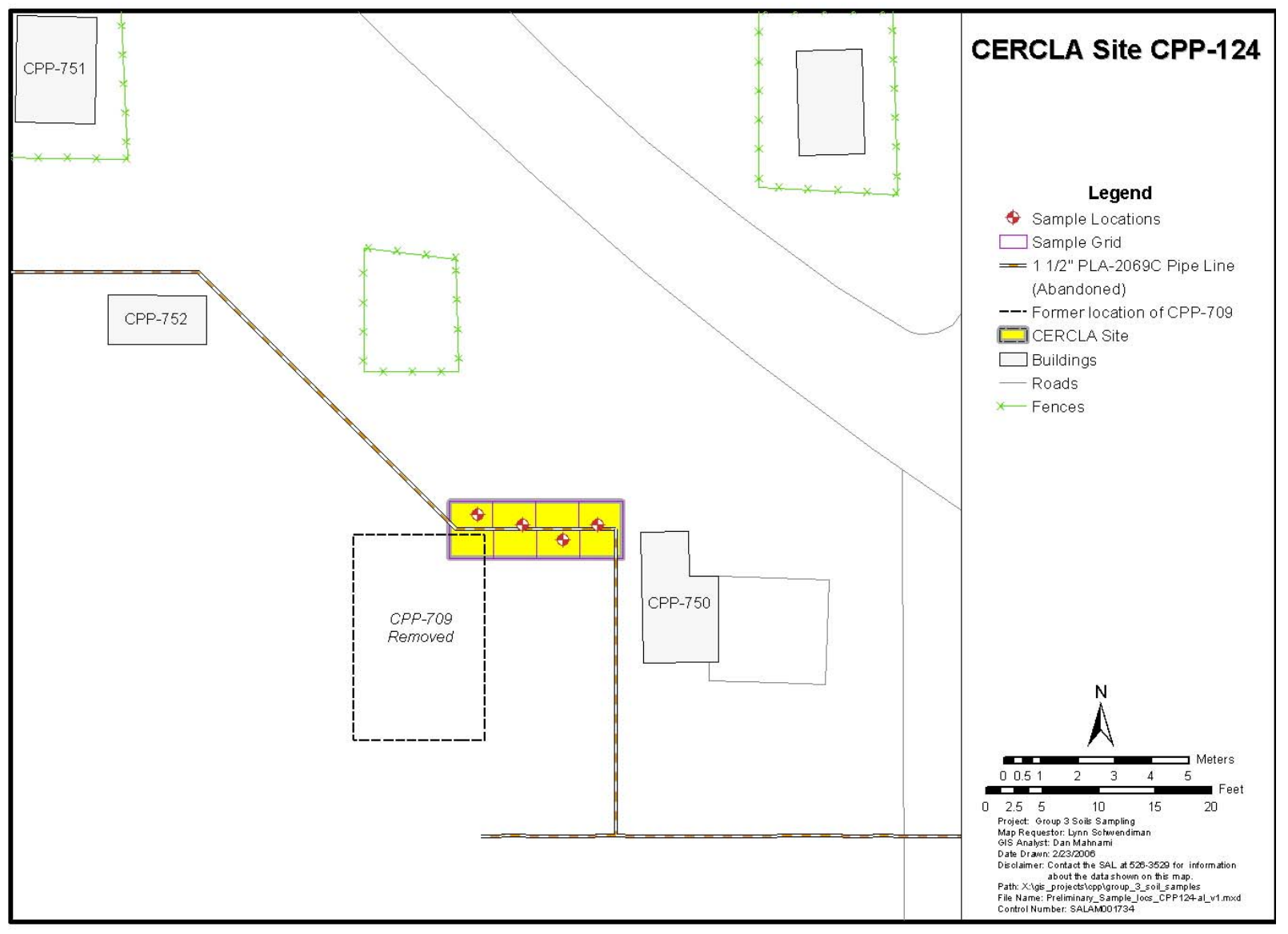

Figure 4-1. CPP-124 characterization sample locations.

4.1.2.2 Unexpected Soil Contamination - Sampling and Analysis. At any given Group 3 Phase II excavation there is a potential to encounter contamination that is unexpected or obviously different from the known site conditions. The process for managing this scenario is discussed in Section 1.3.2 of the Group 3 Phase II Remedial Design/Remedial Action Work Plan and includes the potential for additional sampling and analysis to identify COCs. The unexpected contamination may be more extensive (more volume, outside the site boundaries) or higher levels of the same contamination (same COCs). Additional contamination encountered may also consist of different constituents than those attributed to the site being remediated. Any of these conditions may require additional sampling to determine a path forward as illustrated in the flow diagram (Figure 1-4) in the Remedial Design/Remedial Action Work Plan (DOE-ID 2006a).

If radionuclide contamination is present, the surface extent will be determined using the real-time soil spectroscopy instrumentation. A minimum of three samples will be collected depending on the area encountered at the surface, and additional samples will be collected per the data quality objectives and sampling requirements identified in Section 3.1. Depending on accessibility and depth, direct push probes may be used to collect subsurface samples. In all cases, the area will be surveyed, a sampling grid established, and the sample locations staked prior to collecting samples. 


\subsubsection{Confirmation Sampling and Analysis (PSQ-2) and (PSQ-3)}

The Group 3 Phase II Remedial Design/Remedial Action Work Plan states that all Group 3 Phase II sites, where the remedy is soil excavation and disposal, will have confirmation sampling and analysis performed on the soil surfaces above $10 \mathrm{ft}$ following remediation to demonstrate that COCs are below remediation goals. Table 4-1 summarizes the confirmation analysis requirements for Phase II sites. Confirmation sampling and analysis strategy of Group 3 Phase II soil sites consists of several components: real-time spectroscopy for radionuclides, real-time sampling and analysis for mercury, and sampling and analysis for total strontium (i.e., Sr-89/90).

For sites that have beta radiation contamination (namely Sr-90), the bottom of the excavation will be sampled to provide information to the Agencies. For information purposes, without a decision attached, an upper $95 \%$ confidence limit that is no more than 1 standard deviation in half-width will be calculated. Using the formula in Section 3.1.7, ES1, this requires 3 samples be collected. The samples will be collected randomly from three equal-sized sub areas on the excavation floor and analyzed for total strontium.

The following sections describe the confirmation sampling and analysis requirements following excavation for Group 3 Phase II sites.

4.1.3.1 Real-Time Spectroscopy (PSQ-2). All of the Group 3 Phase II sites with radionuclide COCs above RGs will be remediated and the final confirmation that remediation is complete will be performed using real-time spectroscopy. Table 4-1 identifies all of the Phase II sites that will have real-time confirmation analysis performed on the remaining sloped soil following excavation. Real-time spectroscopy instrumentation may be used during the excavation of Group 3 Phase II soil sites to minimize costs and provide faster results. The real-time spectroscopy methods are also known as wide area surveying or wide area scanning.

Table 4-1. Summary of Group 3 Phase II sites requiring real-time spectroscopy and confirmation sampling.

\begin{tabular}{|l|cc|cc|}
\hline \multirow{2}{*}{ Phase II Sites } & \multicolumn{2}{|c|}{$\begin{array}{c}\text { Confirmation Sampling and } \\
\text { Analysis (PSQ-3) }\end{array}$} \\
\cline { 2 - 5 } CPP-01 & $\begin{array}{c}\text { Real-Time Soil Spectroscopy (PSQ-2) } \\
\text { Spectroscopy }\end{array}$ & $\begin{array}{c}\text { Estimated } \\
\text { Excavation Depth }\end{array}$ & $\begin{array}{c}\text { Confirmation } \\
\text { Samples }\end{array}$ & Analysis \\
CPP-01S (Dry Well) & Gamma & 10 & 8 & Total -Sr \\
CPP-04/05 & Gamma & 10 & 8 & Total -Sr \\
CPP-08/09 & Gamma & 5 & 8 & Total -Sr \\
CPP-10 & Gamma & 10 & 8 & Total -Sr \\
CPP-11 & Gamma & 10 & 8 & Total -Sr \\
CPP-13 & Gamma & 10 & 8 & Total -Sr \\
CPP-19 & Gamma & 8 & 8 & Total -Sr \\
CPP-35 & Gamma & 10 & 8 & Total -Sr \\
CPP-36 & Gamma & 10 & 8 & Total -Sr \\
CPP-93 & Gamma & 10 & 8 & Total -Sr \\
\hline
\end{tabular}


4.1.3.2 Gamma Spectroscopy Methods. The real-time gamma spectroscopy methods can quantitatively report several radionuclides; however, the methods are calibrated for Cs-137 as the primary radionuclide indicator at the Group 3 Phase II sites. Concentrations are typically reported in $\mathrm{pCi} / \mathrm{g}$, with 1-sigma counting uncertainty. All results are reported along with uncertainties and minimum detectable activities.

In-situ gamma spectrometry systems include either the high-purity germanium or Backpack Spectroscopy System (BaSS) will be used in field mode. The in-field mode, a 40-60\% efficient high-purity germanium detector is placed on a tripod and pointed in a downward direction. The height of the detector above the ground surface determines the field of view the detector "sees." This height can be easily varied such that the detector field of view can range from 10 to $70 \mathrm{ft}$ in diameter.

The BaSS detector is carried and attached to a backpack containing a computer and GPS. The Sodium Iodide (NaI) detector or equivalent (e.g., CsI, LaBr) can identify concentrations of Cs-137 in real-time. The system can be used to walk across a given area and then the concentrations plotted to a figure to determine areas of highest concentration. Results from these real-time soil spectroscopy will be used by project management to confirm whether remedial action objectives have been achieved, or whether further remediation is needed.

Background radiation ranges will be obtained by measuring the naturally occurring radiation of uncontaminated soils in areas upwind of the sampling areas. The BaSS instrumentation calibration and performance will be verified using NIST-traceable standards or performance testing standards and since the high-purity germanium system is also calibrated using NIST traceable standards it serves as the benchmark for the BaSS system response.

The use of spectroscopy instrumentation will be performed in coordination with the health and safety officer, radiological engineer, and the radiological control technician. Radiological contaminants will be identified when surface surveys indicate a reading greater than the values specified in ICP radiological release surveys and control/movement of contaminated materials pre-established limits.

\subsubsection{Mercury Sampling and Analysis Methods (PSQ-3).}

CPP-93 Simulated Calcine Disposal Trench-Mercury $(\mathbf{H g})$. Confirmation sampling and analysis will be performed on site CPP-93 following excavation. Figure 4-2 shows the sample locations. A minimum of eight random samples will be collected as defined by the data quality objectives (PSQ3) and analyzed to determine if any remaining mercury contamination is below remediation goals and the excavation is complete. If the analysis determines the soil contamination is below the remediation goals, the remediation of site CPP-93 will be complete and the analysis results reported in the Group 3 Phase II RA Report.

Real-time screening for mercury contamination at Group 3 site CPP-93 will be performed using field mercury analyzers capable of analyzing mercury contamination in soil. Two field instruments have real-time mercury analysis capabilities in air and soil. The Jerome Mercury Vapor Analyzer and the Ohio Lumex Mercury Analyzer can detect part per billion levels of mercury in air and soil. These instruments (or their equivalent) will be used for both real-time screening and confirmation analysis of the soil following site excavations as described in the Group 3 Phase II Remedial Design/Remedial Action Work Plan. 


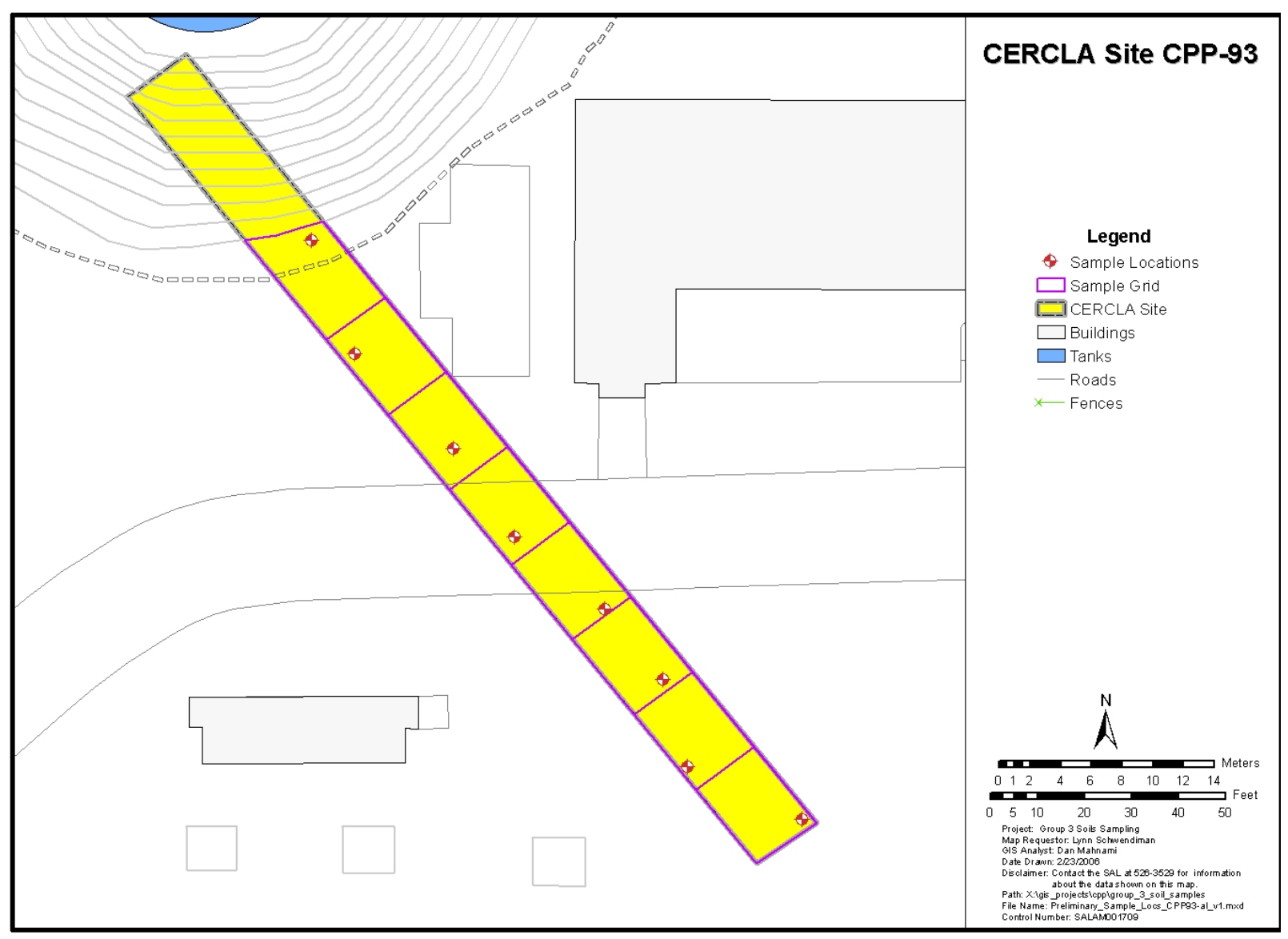

Figure 4-2. CPP-93 sampling grid location.

4.1.3.4 Total Strontium Sampling and Analysis (PSQ-3). The following Group 3 Phase II soil sites will be analyzed for Strontium 90 as total strontium following excavation:

- $\quad$ CPP-01 - Concrete settling basins

- $\quad$ CPP-01S - Dry wells east of CPP-603

- $\quad$ CPP-04/05 - Contaminated soil area around CPP-603 settling tanks and settling basin

- $\quad$ CPP-08/09 - Basin filter system line failure and soil contamination at northeast corner of CPP-603 south basin

- $\quad$ CPP-10 - CPP-603 plastic line leak

- $\quad$ CPP-11 - CPP-603 sludge and water release

- $\quad$ CPP-19 - CPP-603 to CPP-604 line leak

- $\quad$ CPP-13 - Pressurization of solid storage cyclone release northeast of CPP-633

- $\quad$ CPP-35 - CPP-633 decontamination spill

- $\quad$ CPP-36 - Transfer line leak from CPP-633. 
Total strontium is reported as Sr-89/90 when the isotopic in-growth for Y-90 is not performed. The total strontium analysis in soil is faster and more conservative when used for RG confirmation purposes.

Eleven samples will be collected from each site following excavation from a grid similar to the grid identified in Appendix B. Each slope of the excavation will be sampled and three samples will be collected from the bottom of the excavation for information purposes. These samples will be grab samples from random locations.

\subsection{Field Sampling and Analysis Requirements}

\subsubsection{General Field Sampling Requirements}

Radiological control technician field personnel may collect samples wherever radiological scanning (using a Ludlum or equivalent meter) identifies areas of soil contamination significantly above background levels. If action levels for health and safety concerns are sustained in the breathing zones, field personnel will be required to wear appropriate personal protective equipment as determined by health and safety personnel. These operational samples will not be included in the Group 3 sites data set.

Equipment rinsates will be collected from the sampling equipment that was used to collect the particular sample (e.g., hand auger, core barrel, stainless steel spoon) as required by the QAPjP (DOE-ID 2004a). The field team members will use field guidance forms from ICP sample and analysis management to ensure the proper jars and preservatives are used for each analysis type. Field blanks and duplicate samples will be collected.

Tables 6-1 and Table 6-2 of this FSP identify the container volumes, types, holding times, and preservative requirements that apply to all soil and liquid samples being collected under this FSP. Following collection, the date and time of collection, as well as the sampler's initials, will be recorded on the sample label with a waterproof black marker and then covered with clear tape. The samples will be placed in coolers with Blue Ice $^{\mathrm{TM}^{\mathrm{a}}}$ (if required) while awaiting preparation and shipment to the appropriate laboratory. Samples will be prepared and packaged in accordance with ICP chain-of-custody and sample labeling procedures.

New disposable equipment or decontaminated non-disposable equipment will be used between each sample set to avoid cross contamination. A detailed description of the material will be recorded in the logbook.

Industrial hygiene will monitor the work areas suspected of organic contamination prior to or during sampling activities to check for the presence of potentially toxic vapors. The radiological control technician will survey the designated sampling locations and ensure all work is performed in compliance with the Radiation Work Permit, where applicable. Using appropriate equipment, the project radiological control technician will survey all samples obtained from this area for external contamination. The result will be documented on the sample label and the chain-of-custody form (discussed in Section 6). Requirements for release of materials from the Group 3, Other Surface Soils, will be directed by the radiological control technician assigned to the sampling.

a. References herein to any specific commercial product, process, or service by trade name, trademark, manufacturer, or otherwise, does not necessarily constitute or imply its endorsement, recommendation, or favoring by the U.S. Government, any agency thereof, or any company affiliated with the Idaho National Laboratory. 


\subsubsection{Field Instrument Calibration}

4.2.2.1 Gamma Logging Tool. The gamma-ray probe will be calibrated in accordance with industry-recognized procedures in certified probehole calibration models. A section of the driven probe rod will be assembled over the logging sonde during calibration. Calibration in this configuration incorporates the casing thickness correction, because the probe wall thickness is included in the calibration. This method of calibration is more rigorous than applying a casing thickness correction separately during data analysis.

A second field calibration method will also be used. All probeholes will be gamma logged, and the in situ measurements in counts/second will be correlated to laboratory results in $\mathrm{pCi} / \mathrm{g}$ for total gamma emitters for each interval.

4.2.2.2 Gamma Detectors. The high-purity germanium detectors are laboratory calibrated using National Institute of Standards traceable point sources, and quality control checks are performed and charted on every detector at least twice weekly.

The BaSS is calibrated against the high-purity germanium system currently used for field measurements. This calibration serves two purposes: (1) provide calibration coefficients for the BaSS system to allow for conversion of net count rate data to Cs-137 concentrations (in soil) in units of pCi $/ \mathrm{g}$, and (2) to provide a basis of comparability between the two systems. Since the high-purity germanium systems are calibrated using National Institute of Standards traceable standards, it serves as the benchmark for the BaSS system response. However, in areas such as the INTEC sites where multiple gamma-ray emitting radionuclides may be present, the BaSS will be calibrated using National Institute of Standards traceable point sources following the Environmental Measurements Laboratory protocol (FEMP 2001).

4.2.2.3 Mercury Vapor Analyzer. The Jerome gold film sensor is inherently stable and does not require frequent calibration. The Jerome instrument is factory calibrated using laboratory equipment containing National Institute of Standards traceable permeation tubes. Depending on the frequency of use, it is recommended that the interval of calibration be every 12 months. The Lumex Mercury Analyzer is calibrated using the National Institute of Standards to establish a calibration curve depending on the expected level of mercury contamination in the soil.

Calibration of all field instruments will be performed in accordance with appropriate procedures and the QAPjP (DOE-ID 2004a).

\subsubsection{Gamma Shielding/Background}

The Group 3 Phase II sites present a multifaceted problem of dynamic background conditions for most isotopes. This results in measurement scenarios for both the Backpack Sodium Iodide System (BaSIS) and high purity germanium that require variable shielding configurations. Both systems can be equipped with variable thickness bismuth or lead collimators and shielding, in order to mitigate background induced counting scenarios. In addition, carefully considered background measurements will be taken in order to properly correct for local background conditions.

\subsubsection{Field Data Records}

The raw data from the field instruments will be downloaded on a daily basis. Raw data will be processed as necessary to produce final data sets, which for each data point will include name, depth, and instrument gross gamma-ray reading in counts/sec. 
Following the gamma logging event or the real-time spectroscopy activities, a written field data summary report will be prepared containing the following:

- Description of field activities

- $\quad$ Description of equipment

- Instrument calibration documentation

- $\quad$ Results including gamma-ray radiation log plots

- Interpretation and recommendations.

This report of spectroscopy results will be submitted to the project manager and included in the project file for use in preparing the OU 3-13 Phase II Remedial Action report.

\subsection{Laboratory Sample Analysis}

Laboratories approved by the sample and analysis management group will perform sample analysis. These laboratories will perform analyses in accordance with project requirements. Laboratory analysis will be performed on Group 3 Phase II sites requiring initial characterization sampling and analysis (i.e., CPP-124).

Project-specific requests for analyses forms identify additional requirements for laboratory analysis. The following sections identify analysis requirements for this project.

\subsubsection{Analytical Methods}

To ensure that data of acceptable quality are obtained from characterization projects, standard Environmental Protection Agency laboratory methods or technically appropriate methods for analytical determinations will be used. References for the most commonly used methods are listed here:

- $\quad$ Soil Sampling and Analysis for Volatile Organic Compounds (EPA 1991a, pages 1-22)

- $\quad$ Characterizing Soils for Hazardous Waste Site Assessments (EPA 1991b, pages 1-16)

- $\quad$ A Compendium of Superfund Field Operations Methods (EPA 1987, pages 7-1 through 7-9, 8.1-1 through 8.4-51, 13-1 through 13-10, 15-1 through 15-58)

- $\quad$ Statement of Work for Organic Analysis-Multimedia, Multi-Concentration (EPA 1994)

- $\quad$ Statement of Work for Inorganic Analysis-Multimedia, Multi-Concentration (EPA 1993)

- $\quad$ Test Methods for Evaluating Solid Waste, Physical and Chemical Methods (EPA 1996)

- $\quad$ Methods for the Chemical Analysis of Water and Wastes (EPA 1983).

The general sample volumes, preservation requirements, container types, and holding times for many of the typically required analyses can be found in Tables 2-1 and 2-2 of the QAPjP (DOE-ID 2004a). American Society for Testing and Materials or Environmental Protection Agency sampling methods will be used whenever possible. The specific information related to sampling bottles, preservation types, and holding times is found in Table 4-2 for radionuclide analysis and Table 4-3 for inorganic and organic analysis. The analytes and isotopes listed in these tables are only examples of potential analysis candidates. 
Table 4-2. Summary of sample collection, holding time, and preservation requirements for radiological analyses.

\begin{tabular}{|c|c|c|c|c|c|c|c|c|}
\hline Radionuclide & Method $^{\mathrm{a}}$ & $\begin{array}{c}\text { Analysis } \\
\text { (Alpha/Gamma/Specific) }\end{array}$ & $\begin{array}{l}\text { Decommended } \\
\text { Dimit } \\
(\mathrm{pCi} / \mathrm{g})^{\mathrm{b}} \\
\end{array}$ & $\begin{array}{c}\text { Sample } \\
\text { Media }\end{array}$ & $\begin{array}{c}\text { Container } \\
\text { Size }^{c}\end{array}$ & Container Type & $\begin{array}{c}\text { Holding } \\
\text { Time }{ }^{\mathrm{d}} \\
\text { (Months) }\end{array}$ & $\begin{array}{c}\text { Sample } \\
\text { Preservation }\end{array}$ \\
\hline Cs-137 & ER-SOW-394 & Gamma & 0.1 & Soil & $16 \mathrm{oz}$ & Wide-Mouth Plastic Jar & 6 & None \\
\hline $\mathrm{Pu}-238$ & ER-SOW-394 & Alpha & 0.05 & Soil & & Wide-Mouth Plastic Jar & 6 & None \\
\hline $\mathrm{Pu}-239 / 240$ & ER-SOW-394 & Alpha & 0.05 & Soil & & Wide-Mouth Plastic Jar & 6 & None \\
\hline Am-241 & ER-SOW-394 & Alpha & 0.05 & Soil & & Wide-Mouth Plastic Jar & 6 & None \\
\hline $\mathrm{Cm}-242$ & ER-SOW-394 & Alpha & 0.05 & Soil & & Wide-Mouth Plastic Jar & 6 & None \\
\hline $\mathrm{Cm}-243 / 244$ & ER-SOW-394 & Alpha & 0.05 & Soil & & Wide-Mouth Plastic Jar & 6 & None \\
\hline Np-237 & ER-SOW-394 & Alpha & 0.05 & Soil & & Wide-Mouth Plastic Jar & 6 & None \\
\hline U-233/234 & ER-SOW-394 & Alpha & 0.05 & Soil & & Wide-Mouth Plastic Jar & 6 & None \\
\hline U-235 & ER-SOW-394 & Alpha & 0.05 & Soil & & Wide-Mouth Plastic Jar & 6 & None \\
\hline $\mathrm{U}-238$ & ER-SOW-394 & Alpha & 0.05 & Soil & & Wide-Mouth Plastic Jar & 6 & None \\
\hline Co-60 & ER-SOW-394 & Gamma & $\mathrm{TBD}^{\mathrm{e}}$ & Soil & & Wide-Mouth Plastic Jar & 6 & None \\
\hline Cs-134 & ER-SOW-394 & Gamma & $\mathrm{TBD}^{\mathrm{e}}$ & Soil & & Wide-Mouth Plastic Jar & 6 & None \\
\hline $\mathrm{Eu}-152$ & ER-SOW-394 & Gamma & $\mathrm{TBD}^{\mathrm{e}}$ & Soil & & Wide-Mouth Plastic Jar & 6 & None \\
\hline Eu-154 & ER-SOW-394 & Gamma & $\mathrm{TBD}^{\mathrm{e}}$ & Soil & & Wide-Mouth Plastic Jar & 6 & None \\
\hline $\mathrm{Eu}-155$ & ER-SOW-394 & Gamma & $\mathrm{TBD}^{\mathrm{e}}$ & Soil & & Wide-Mouth Plastic Jar & 6 & None \\
\hline $\mathrm{Sb}-125$ & ER-SOW-394 & Gamma & $\mathrm{TBD}^{\mathrm{e}}$ & Soil & & Wide-Mouth Plastic Jar & 6 & None \\
\hline Sr-90 & ER-SOW-394 & Specific & $\mathrm{TBD}^{\mathrm{e}}$ & Soil & & Wide Mouth Plastic Jar & 6 & None \\
\hline $\mathrm{I}-129$ & ER-SOW-394 & Specific & 1.0 & Soil & & Wide-Mouth Plastic Jar ${ }^{\mathrm{f}}$ & 6 & $4^{\circ} \mathrm{C}$ \\
\hline $\mathrm{Ni}-63$ & ER-SOW-394 & Specific & 5.0 & Soil & & Wide-Mouth Plastic Jar & 6 & None \\
\hline Ag- $108 \mathrm{~m}$ & ER-SOW-394 & Gamma & $\mathrm{TBD}^{\mathrm{e}}$ & Soil & & Wide-Mouth Plastic Jar & 6 & None \\
\hline $\mathrm{Ag}-110 \mathrm{~m}$ & ER-SOW-394 & Gamma & $\mathrm{TBD}^{\mathrm{e}}$ & Soil & & Wide-Mouth Plastic Jar & 6 & None \\
\hline Ce-144 & ER-SOW-394 & Gamma & $\mathrm{TBD}^{\mathrm{e}}$ & Soil & & Wide-Mouth Plastic Jar & 6 & None \\
\hline
\end{tabular}


Table 4-2. (continued).

\begin{tabular}{|c|c|c|c|c|c|c|c|c|}
\hline Radionuclide & Method $^{\mathrm{a}}$ & $\begin{array}{c}\text { Analysis } \\
\text { (Alpha/Gamma/Specific) }\end{array}$ & $\begin{array}{l}\text { Recommended } \\
\text { Detection } \\
\text { Limit } \\
(\mathrm{pCi} / \mathrm{g})^{\mathrm{b}} \\
\end{array}$ & $\begin{array}{c}\text { Sample } \\
\text { Media }\end{array}$ & $\begin{array}{c}\text { Container } \\
\text { Size }^{\mathrm{c}}\end{array}$ & Container Type & $\begin{array}{c}\text { Holding } \\
\text { Time }^{\mathrm{d}} \\
\text { (Months) }\end{array}$ & $\begin{array}{c}\text { Sample } \\
\text { Preservation }\end{array}$ \\
\hline Co-58 & ER-SOW-394 & Gamma & $\mathrm{TBD}^{\mathrm{e}}$ & Soil & & Wide-Mouth Plastic Jar & 6 & None \\
\hline $\mathrm{Nb}-95$ & ER-SOW-394 & Gamma & $\mathrm{TBD}^{\mathrm{e}}$ & Soil & & Wide-Mouth Plastic Jar & 6 & None \\
\hline Ra-226 & ER-SOW-394 & Specific & 0.5 & Soil & & Wide-Mouth Plastic Jar & 6 & None \\
\hline $\mathrm{Ru}-103$ & ER-SOW-394 & Gamma & $\mathrm{TBD}^{\mathrm{e}}$ & Soil & & Wide-Mouth Plastic Jar & 6 & None \\
\hline $\mathrm{Ru}-106$ & ER-SOW-394 & Gamma & $\mathrm{TBD}^{\mathrm{e}}$ & Soil & & Wide-Mouth Plastic Jar & 6 & None \\
\hline
\end{tabular}

a. ER-SOW-394, 2004, “Idaho National Laboratory Sample and Analysis Management Statement of Work for Analytical Services,” Rev. 2, May 2004

b. Recommended detection limits are provided for information purposes only. These limits are for use by the analytical laboratory and do not impact field sampling activities.

c. Volumes vary depending on the requested analysis and the laboratory performing the analysis. Exact volumes required will be specified to project personnel following final determination of the analytical services provider. In general, one 16-oz sample can be used to complete the required analyses; however, it may be desirable to provide three 16 oz. samples to expedite analysis, one for gamma analysis, one for alpha analysis, and one for specific radiochemical analysis.

d. The holding time requirement of 6 months is described in 40 CFR 136 (EPA guidelines for analysis of pollutants) and is applied in this FSP as a general guideline. For analysis of volatile radionuclides not listed above or radionuclides with short half-lives (e.g., 131I), the holding times will be adjusted accordingly and disseminated to the laboratory via a project-specific statement of work.

e. All gamma emitting isotopes shall have a detection limit commensurate with their photon yield and energy as related to the Cs-137 detection limit.

f. Collecting samples for I-129 in HDPE containers is permissible/acceptable; however, the holding time requirement is 28 days (instead of 6 months).

$\mathrm{CFR}=$ Code of Federal Regulations

$\mathrm{EPA}=$ U.S. Environmental Protection Agency

ER-SOW $=$ Environmental Restoration Statement of Work

FSP $=$ field sampling plan

HDPE $=$ high-density polyethylene

$\mathrm{TBD}=$ to be determined 
Table 4-3. Summary of sample collection, holding time, and preservation requirements for samples collected for inorganic and organic analyses.

\begin{tabular}{|c|c|c|c|c|c|c|c|c|c|}
\hline Contaminant $^{\mathrm{a}}$ & CAS & $\begin{array}{l}\text { SW-846 } \\
\text { Preparation } \\
\text { Method }^{\mathrm{b}}\end{array}$ & $\begin{array}{l}\text { SW-846 Analysis } \\
\text { Method }^{\mathrm{b}}\end{array}$ & $\begin{array}{l}\text { Recommended } \\
\text { s Detection Limit } \\
\quad(\mathrm{mg} / \mathrm{Kg})^{\mathrm{c}, \mathrm{d}, \mathrm{e}}\end{array}$ & $\begin{array}{l}\text { Sample } \\
\text { Media }\end{array}$ & $\begin{array}{c}\text { Container } \\
\text { Size }\end{array}$ & Container Type & $\begin{array}{l}\text { Holding Time } \\
\text { (Months) }\end{array}$ & $\begin{array}{c}\text { Sample } \\
\text { Preservation }\end{array}$ \\
\hline \multicolumn{10}{|l|}{ Metals } \\
\hline $\mathrm{Ag}$ & $7440-22-4$ & $\begin{array}{c}\text { SW846-3050B or } \\
3051\end{array}$ & SW846-6010B & 10.0 & Soil & $60 \mathrm{~mL}$ & WM Glass Bottle & 6 & $4^{\circ} \mathrm{C}$ \\
\hline $\mathrm{Al}$ & $7429-90-5$ & $\begin{array}{c}\text { SW846-3050B or } \\
3051\end{array}$ & SW846-6010B & 60.0 & Soil & & WM Glass Bottle & 6 & $4^{\circ} \mathrm{C}$ \\
\hline As & $7440-38-2$ & $\begin{array}{c}\text { SW846-3050B or } \\
3051\end{array}$ & SW846-6010B & 70.0 & Soil & & WM Glass Bottle & 6 & $4^{\circ} \mathrm{C}$ \\
\hline $\mathrm{Ba}$ & $7440-39-3$ & $\begin{array}{c}\text { SW846-3050B or } \\
3051\end{array}$ & SW846-6010B & 2.0 & Soil & & WM Glass Bottle & 6 & $4^{\circ} \mathrm{C}$ \\
\hline $\mathrm{Be}$ & $7440-41-7$ & $\begin{array}{c}\text { SW846-3050B or } \\
3051\end{array}$ & SW846-6010B & 0.4 & Soil & & WM Glass Bottle & 6 & $4^{\circ} \mathrm{C}$ \\
\hline $\mathrm{Cd}$ & $7440-43-9$ & $\begin{array}{c}\text { SW846-3050B or } \\
3051\end{array}$ & SW846-6010B & 5.0 & Soil & & WM Glass Bottle & 6 & $4^{\circ} \mathrm{C}$ \\
\hline $\mathrm{Cr}$ & $7440-47-3$ & $\begin{array}{c}\text { SW846-3050B or } \\
3051\end{array}$ & SW846-6010B & 10.0 & Soil & & WM Glass Bottle & 6 & $4^{\circ} \mathrm{C}$ \\
\hline $\mathrm{Fe}$ & $7439-89-6$ & $\begin{array}{c}\text { SW846-3050B or } \\
3051\end{array}$ & SW846-6010B & 9.0 & Soil & & WM Glass Bottle & 6 & $4^{\circ} \mathrm{C}$ \\
\hline $\mathrm{Mn}$ & $7439-96-5$ & $\begin{array}{c}\text { SW846-3050B or } \\
3051\end{array}$ & SW846-6010B & 2.0 & Soil & & WM Glass Bottle & 6 & $4^{\circ} \mathrm{C}$ \\
\hline $\mathrm{Ni}$ & $7440-02-0$ & $\begin{array}{c}\text { SW846-3050B or } \\
3051\end{array}$ & SW846-6010B & 20.0 & Soil & & WM Glass Bottle & 6 & $4^{\circ} \mathrm{C}$ \\
\hline $\mathrm{P}$ & $7723-14-0$ & $\begin{array}{c}\text { SW846-3050B or } \\
3051\end{array}$ & SW846-6010B & 100.0 & Soil & & WM Glass Bottle & 6 & $4^{\circ} \mathrm{C}$ \\
\hline $\mathrm{Pb}$ & $7439-92-1$ & $\begin{array}{c}\text { SW846-3050B or } \\
3051\end{array}$ & SW846-7420 & 0.6 & Soil & & WM Glass Bottle & 6 & $4^{\circ} \mathrm{C}$ \\
\hline $\mathrm{Sb}$ & $7440-36-0$ & $\begin{array}{c}\text { SW846-3050B or } \\
3051\end{array}$ & SW846-6010B & 40.0 & Soil & & WM Glass Bottle & 6 & $4^{\circ} \mathrm{C}$ \\
\hline $\mathrm{Se}$ & $7782-49-2$ & $\begin{array}{c}\text { SW846-3050B or } \\
3051\end{array}$ & SW846-6010B & 100.0 & Soil & & WM Glass Bottle & 6 & $4^{\circ} \mathrm{C}$ \\
\hline $\mathrm{Tl}$ & $7440-28-0$ & $\begin{array}{c}\text { SW846-3050B or } \\
3051\end{array}$ & SW846-6010B & 55.0 & Soil & & WM Glass Bottle & 6 & $4^{\circ} \mathrm{C}$ \\
\hline V & $7440-62-2$ & $\begin{array}{c}\text { SW846-3050B or } \\
3051 \\
\end{array}$ & SW846-6010B & 10.0 & Soil & & WM Glass Bottle & 6 & $4^{\circ} \mathrm{C}$ \\
\hline
\end{tabular}


Table 4-3. (continued).

\begin{tabular}{|c|c|c|c|c|c|c|c|c|c|}
\hline Contaminant $^{\mathrm{a}}$ & CAS & $\begin{array}{l}\text { SW-846 } \\
\text { Preparation } \\
\text { Method }^{\mathrm{b}}\end{array}$ & $\begin{array}{l}\text { SW-846 Analysis } \\
\text { Method }^{\mathrm{b}}\end{array}$ & $\begin{array}{l}\text { Recommended } \\
\text { Detection Limit } \\
(\mathrm{mg} / \mathrm{Kg})^{\mathrm{c}, \mathrm{d}, \mathrm{e}}\end{array}$ & $\begin{array}{c}\text { Sample } \\
\text { Media }\end{array}$ & $\begin{array}{c}\text { Container } \\
\text { Size }\end{array}$ & Container Type & $\begin{array}{l}\text { Holding Time } \\
\text { (Months) }\end{array}$ & $\begin{array}{c}\text { Sample } \\
\text { Preservation }\end{array}$ \\
\hline $\mathrm{Zn}$ & $7440-66-6$ & $\begin{array}{c}\text { SW846-3050B or } \\
3051\end{array}$ & SW846-6010B & 3.0 & Soil & & WM Glass Bottle & 6 & $4^{\circ} \mathrm{C}$ \\
\hline $\mathrm{Hg}$ & $7439-97-6$ & SW846-7471A & & 0.08 & Soil & $30 \mathrm{~mL}$ & WM Glass Bottle & 28 Days & $4^{\circ} \mathrm{C}$ \\
\hline \multicolumn{10}{|c|}{ Semi-Volatile Organic Analytes } \\
\hline \multicolumn{10}{|c|}{ Polychlorinated Byphenyls } \\
\hline Aroclor-1260 & $11096-82-5$ & $\begin{array}{c}\text { SW846-3540 or } \\
3541\end{array}$ & SW846-8082 & 0.033 & Soil & $250 \mathrm{~mL}$ & WM Amber Glass Bottle & $\begin{array}{l}14 \text { Days/ } \\
\text { 40 Days }{ }^{\mathrm{f}}\end{array}$ & $4^{\circ} \mathrm{C}$ \\
\hline \multicolumn{10}{|c|}{ Volatile Organic Analytes } \\
\hline 1,1-dichloroethane & $75-34-3$ & $\begin{array}{c}\text { SW846- } \\
50355035 \mathrm{~A}\end{array}$ & SW846-8260B & 0.01 & Soil & $40125 \mathrm{~mL}$ & $\begin{array}{l}\text { WM Amber Glass } \\
\text { Bottle Preserved Kit }\end{array}$ & 14 Days & $4^{\circ} \mathrm{C}$ \\
\hline $\begin{array}{c}1,2- \\
\text { dichloroethylene }\end{array}$ & $540-59-0$ & $\begin{array}{c}\text { SW846- } \\
50355035 \mathrm{~A}\end{array}$ & SW846-8260B & 0.01 & Soil & & $\begin{array}{l}\text { WM Amber Glass } \\
\text { Bottle Preserved Kit }\end{array}$ & 14 Days & $4^{\circ} \mathrm{C}$ \\
\hline bromomethane & $74-83-9$ & $\begin{array}{c}\text { SW846- } \\
\text { 50355035A }\end{array}$ & SW846-8260B & 0.01 & Soil & & $\begin{array}{l}\text { Preserved Kit WM } \\
\text { Amber Glass Bottle }\end{array}$ & 14 Days & $4^{\circ} \mathrm{C}$ \\
\hline chloromethane & $74-87-3$ & $\begin{array}{l}\text { SW846- } \\
\text { 50355035A }\end{array}$ & SW846-8260B & 0.01 & Soil & & $\begin{array}{l}\text { Preserved Kit WM } \\
\text { Amber Glass Bottle }\end{array}$ & 14 Days & $4^{\circ} \mathrm{C}$ \\
\hline methylene chloride & $75-09-2$ & $\begin{array}{l}\text { SW846- } \\
\text { 50355035A }\end{array}$ & SW846-8260B & 0.01 & Soil & & $\begin{array}{l}\text { Preserved Kit WM } \\
\text { Amber Glass Bottle }\end{array}$ & 14 Days & $4^{\circ} \mathrm{C}$ \\
\hline tetrachloroethene & $127-18-4$ & $\begin{array}{l}\text { SW846- } \\
\text { 50355035A }\end{array}$ & SW846-8260B & 0.01 & Soil & & $\begin{array}{l}\text { Preserved Kit WM } \\
\text { Amber Glass Bottle }\end{array}$ & 14 Days & $4^{\circ} \mathrm{C}$ \\
\hline trichloroethene & 79-01-6 & $\begin{array}{c}\text { SW846- } \\
\text { 50355035A }\end{array}$ & SW846-8260B & 0.01 & Soil & & $\begin{array}{l}\text { Preserved Kit WM } \\
\text { Amber Glass Bottle }\end{array}$ & 14 Days & $4^{\circ} \mathrm{C}$ \\
\hline trichlrorethane & $25323-89-1$ & $\begin{array}{l}\text { SW846- } \\
\text { 50355035A }\end{array}$ & SW846-8260B & 0.01 & Soil & & $\begin{array}{l}\text { Preserved Kit WM } \\
\text { Amber Glass Bottle }\end{array}$ & 14 Days & $4^{\circ} \mathrm{C}$ \\
\hline vinyl chloride & 75-01-4 & $\begin{array}{c}\text { SW846- } \\
\text { 50355035A }\end{array}$ & SW846-8260B & 0.01 & Soil & & $\begin{array}{l}\text { Preserved Kit WM } \\
\text { Amber Glass Bottle }\end{array}$ & 14 Days & $4^{\circ} \mathrm{C}$ \\
\hline \multicolumn{10}{|c|}{ Semivolatile Organic Analytes } \\
\hline $\begin{array}{c}1,2.4- \\
\text { trichlorobenzene }\end{array}$ & $120-82-1$ & $\begin{array}{c}\text { SW846-3540 } \\
\text { or } 3541\end{array}$ & SW846-8270C & 0.33 & Soil & & WM Amber Glass Bottle & $\begin{array}{l}14 \text { Days/ } \\
40 \text { Days }{ }^{\mathrm{f}}\end{array}$ & $4^{\circ} \mathrm{C}$ \\
\hline $\begin{array}{c}1,2- \\
\text { dichlorobenzene }\end{array}$ & $95-50-1$ & $\begin{array}{l}\text { SW846-3540 } \\
\text { or } 3541\end{array}$ & SW846-8270C & 0.33 & Soil & & WM Amber Glass Bottle & $\begin{array}{l}14 \text { Days/ } \\
40 \text { Days }\end{array}$ & $4^{\circ} \mathrm{C}$ \\
\hline $\begin{array}{c}1,3- \\
\text { dichlorobenzene }\end{array}$ & $541-73-1$ & $\begin{array}{c}\text { SW846-3540 } \\
\text { or } 3541\end{array}$ & SW846-8270C & 0.33 & Soil & & WM Amber Glass Bottle & $\begin{array}{l}14 \text { Days/ } \\
40 \text { Days }\end{array}$ & $4^{\circ} \mathrm{C}$ \\
\hline
\end{tabular}


Table 4-3. (continued).

\begin{tabular}{|c|c|c|c|c|c|c|c|c|c|}
\hline Contaminant $^{\mathrm{a}}$ & CAS & $\begin{array}{l}\text { SW-846 } \\
\text { Preparation } \\
\text { Method }^{\mathrm{b}}\end{array}$ & $\begin{array}{l}\text { SW-846 Analysis } \\
\text { Method }^{\mathrm{b}}\end{array}$ & $\begin{array}{l}\text { Recommended } \\
\text { Detection Limit } \\
(\mathrm{mg} / \mathrm{Kg})^{\mathrm{c}, \mathrm{d}, \mathrm{e}}\end{array}$ & $\begin{array}{l}\text { Sample } \\
\text { Media }\end{array}$ & $\begin{array}{c}\text { Container } \\
\text { Size }\end{array}$ & Container Type & $\begin{array}{l}\text { Folding Time } \\
\text { (Months) }\end{array}$ & $\begin{array}{c}\text { Sample } \\
\text { Preservation }\end{array}$ \\
\hline $\begin{array}{c}1,4- \\
\text { dichlorobenzene }\end{array}$ & $106-46-7$ & $\begin{array}{c}\text { SW846-3540 } \\
\text { or } 3541\end{array}$ & SW846-8270C & 0.33 & Soil & & WM Amber Glass Bottle & $\begin{array}{l}14 \text { Days/ } \\
40 \text { Days }{ }^{\mathrm{f}}\end{array}$ & $4^{\circ} \mathrm{C}$ \\
\hline $\begin{array}{c}2,4- \\
\text { dimethylphenol }\end{array}$ & $105-67-9$ & $\begin{array}{c}\text { SW846-3540 } \\
\text { or } 3541\end{array}$ & SW846-8270C & 0.33 & Soil & & WM Amber Glass Bottle & $\begin{array}{l}14 \text { Days/ } \\
40 \text { Days }^{\mathrm{f}}\end{array}$ & $4^{\circ} \mathrm{C}$ \\
\hline 2-methylphenol & $95-48-7$ & $\begin{array}{c}\text { SW846-3540 } \\
\text { or } 3541\end{array}$ & SW846-8270C & 0.33 & Soil & $250 \mathrm{~mL}$ & WM Amber Glass Bottle & $\begin{array}{l}14 \text { Days/ } \\
40 \text { Days }^{\mathrm{f}}\end{array}$ & $4^{\circ} \mathrm{C}$ \\
\hline $\begin{array}{l}\text { 4,6-dinitro-2- } \\
\text { methylphenol }\end{array}$ & $534-52-1$ & $\begin{array}{c}\text { SW846-3540 } \\
\text { or } 3541\end{array}$ & SW846-8270C & 0.83 & Soil & & WM Amber Glass Bottle & $\begin{array}{l}14 \text { Days/ } \\
40 \text { Days }{ }^{f}\end{array}$ & $4^{\circ} \mathrm{C}$ \\
\hline 4-methylphenol & $106-44-5$ & $\begin{array}{c}\text { SW846-3540 } \\
\text { or } 3541\end{array}$ & SW846-8270C & 0.33 & Soil & & WM Amber Glass Bottle & $\begin{array}{l}14 \text { Days/ } \\
40 \text { Days }{ }^{\mathrm{f}}\end{array}$ & $4^{\circ} \mathrm{C}$ \\
\hline 4-nitrophenol & $100-02-7$ & $\begin{array}{c}\text { SW846-3540 } \\
\text { or } 3541\end{array}$ & SW846-8270C & 0.83 & Soil & & WM Amber Glass Bottle & $\begin{array}{l}14 \text { Days/ } \\
40 \text { Days }\end{array}$ & $4^{\circ} \mathrm{C}$ \\
\hline $\begin{array}{l}\text { bis(2-ethylhexyl) } \\
\text { phthalate }\end{array}$ & $117-81-7$ & $\begin{array}{c}\text { SW846-3540 } \\
\text { or } 3541\end{array}$ & SW846-8270C & 0.33 & Soil & & WM Amber Glass Bottle & $\begin{array}{l}14 \text { Days/ } \\
40 \text { Days }{ }^{\mathrm{f}}\end{array}$ & $4^{\circ} \mathrm{C}$ \\
\hline di-n-butylphthalate & $84-74-2$ & $\begin{array}{c}\text { SW846-3540 } \\
\text { or } 3541\end{array}$ & SW846-8270C & 0.33 & Soi & & WM Amber Glass Bottle & $\begin{array}{l}14 \text { Days/ } \\
40 \text { Days }^{\mathrm{f}}\end{array}$ & $4^{\circ} \mathrm{C}$ \\
\hline di-n-octylphthalate & $117-84-0$ & $\begin{array}{c}\text { SW846-3540 } \\
\text { or } 3541\end{array}$ & SW846- & 0.33 & Soil & & WM Amber Glass Bottle & $\begin{array}{l}14 \text { Days/ } \\
40 \text { Days }^{\mathrm{f}}\end{array}$ & $4^{\circ} \mathrm{C}$ \\
\hline naphthalene & $91-20-3$ & $\begin{array}{c}\text { SW846-3540 } \\
\text { or } 3541\end{array}$ & SW846-8270C & 0.33 & So & & WM Amber Glass Bottle & $\begin{array}{l}14 \text { Days/ } \\
40 \text { Days }{ }^{f}\end{array}$ & $4^{\circ} \mathrm{C}$ \\
\hline phenol & $108-95-2$ & $\begin{array}{c}\text { SW846-3540 } \\
\text { or } 3541\end{array}$ & SW846-8270C & 0.33 & Soil & & WM Amber Glass Bottle & $\begin{array}{l}14 \text { Days/ } \\
40 \text { Days }{ }^{f}\end{array}$ & $4^{\circ} \mathrm{C}$ \\
\hline pyrene & $129-00-0$ & $\begin{array}{c}\text { SW846-3540 } \\
\text { or } 3541\end{array}$ & SW846-8270C & 0.33 & Soil & & WM Amber Glass Bottle & $\begin{array}{l}14 \text { Days/ } \\
\text { 40 Days }{ }^{\mathrm{f}}\end{array}$ & $4^{\circ} \mathrm{C}$ \\
\hline \multicolumn{10}{|c|}{$\begin{array}{l}\text { a. List of potential analytes } \\
\text { b. SW-846 Methods are from EPA } 1986 \text {. } \\
\text { c. Metals method detection limits (MDLs) are based on published instrument detection limits (IDLs) and the following assumptions: The MDL is } 10 \times \text { the IDL; } 1.0 \text { gram soil is } \\
\text { digested and there is no soil moisture present; Method 3050B is used for sample preparation (except for mercury). If Method } 3051 \text { is used for sample preparation, the MDLs are } 0.5 x \\
\text { the value listed. } \\
\text { d. For organic analytes, the values listed are the published practical quantitation limits (PQLs). The PQL is typically } 5-10 \text { times greater than the MDL. } \\
\text { e. Recommended detection limits are provided for information purposes only. These limits are for use by the analytical laboratory and do not impact field sampling activities. } \\
\text { f. Days to extract and days from completion of extraction to complete analysis. } \\
\text { WM = wide-mouth }\end{array}$} \\
\hline
\end{tabular}




\subsubsection{Instrument Calibration Procedures}

Laboratory instrumentation will be calibrated in accordance with each of the specified analytical methods. The laboratory quality assurance plan shall include requirements for calibrations when specifications are not listed in analytical methods. Calibrations that are typically not called out in analytical methods include ancillary laboratory equipment and verification of reference standards used for calibration and standard preparation. Laboratory documentation will include calibration techniques and sequential calibration actions, performance tolerances provided by the specific analytical method, and calibration dates and frequency. All analytical methods have specifications for equipment checks and instrument calibrations. The laboratory will comply with all method-specific calibration requirements for all requested parameters. If a failure of instrument calibration or equipment is detected, the instrument will be recalibrated, and all affected samples will be analyzed using an acceptable calibration.

\subsubsection{Laboratory Records}

Laboratory records are required to document all activities involved in sample receipt, processing, analysis, and data reporting. Sample management records document sample receipt, handling, storage, and the sample analysis schedule. The records (a) verify that the COC and proper preservation were maintained, (b) reflect any anomalies in the samples, (c) note proper log-in of samples into the laboratory, and address procedures used to prioritize received samples to ensure that the holding time requirements are met.

The laboratory is responsible to maintain documentation demonstrating laboratory proficiency with each method as prescribed in standard operating procedures. Laboratory documentation will include sample preparation and analysis detail, instrument standardization, detection and reporting limits, and test-specific QC criteria. Any deviation from prescribed methods must be properly recorded. QA/QC reports will include general QC records, such as analyst training, instrument calibration, routine monitoring of analytical performance, and calibration verification. Project-specific information, such as blanks, spikes, calibration check samples, replicates, and splits performed per project requirements, may be documented. Specific requirements for the quantity and types of QA/QC monitoring and associated reporting formats will be specified in the task-specific laboratory statement of work.

\subsection{Personal Protective Equipment}

The personal protective equipment required for this sampling effort are discussed in the job safety analysis (JSA) and health and safety plan and may include, but is not limited to, gloves, respirator cartridges, shoe covers, and coveralls.

\subsection{Shipping Screening}

Prior to releasing samples collected from radionuclide-contaminated areas of the site, the radiological control technician will field screen all such samples to determine whether they meet the release criteria for unrestricted use. Samples that do not meet these criteria will be submitted to the Analytical Laboratory Department at INTEC area for a 20-minute gamma spectrometric analysis to determine the concentration of radionuclides present and the hazardous material classification for shipping purposes. Shipping screening could be onsite using high-purity germanium, if it is acceptable to the hazardous materials shipper and current ICP policy. All samples will be shipped to the laboratories by a company-certified hazardous materials shipper in accordance with U.S. Department of Transportation regulations and current ICP policy. 


\subsection{Field Decontamination}

Field decontamination procedures are designed to prevent cross-contamination between locations and samples and prevent off-Site contaminant migration. All equipment associated with sampling will be thoroughly decontaminated, in accordance with ICP sample equipment decontamination procedures. Following decontamination, if not immediately used, sampling equipment will be wrapped in plastic to prevent contamination from windblown dust.

\subsection{Sampling Waste Handling and Disposition}

Waste streams generated as a result of sampling activities may include (but not be limited to) personal protective equipment, sample supplies and equipment, decontamination water (which may be used in small quantities during sampling), and excess or spent samples. All waste streams that are generated as a result of the sampling activities will be containerized, maintained, and disposed of in accordance with the project Waste Management Plan (DOE-ID 2006b) and following the directions of the Waste Generator Services waste technical specialist (WGS-WTS).

\subsection{Data Management and Document Control}

\subsubsection{Data Reporting}

Tier I data packages are suggested for all analyses so that Level B validation could be performed at a later date if determined necessary in the future.

This data package prepared by the sample and analysis management organization is the standard by which analytical data deliverable requirements are defined by projects to laboratories used by the ICP. All laboratories used by this project will adhere to the document used to establish technical and reporting standards.

\subsubsection{Data Validation}

Data will be acquired, processed, and controlled prior to input to the Integrated Environmental Data Management System as required by the ICP. For the samples submitted to the analytical laboratory, all data will be validated to Level B, in accordance with the QAPjP (DOE-ID 2004a).

A data limitation and validation report, including copies of chain-of-custody forms, sample results, and validation flags, will be generated for each sample delivery group. All data limitation and validation reports associated with a site will be transmitted to the Environmental Protection Agency and Idaho Department of Environmental Quality within 120 days from the last day of sample collection. All definitive data will be uploaded to the Integrated Environmental Data Management System.

The sample and analysis management group will ensure the data are validated to Level B, as specified. The analytical method data validation will be conducted in accordance with current sample and analysis management data validation procedures. Validated data are entered into the Integrated Environmental Data Management System.

\subsubsection{Data Quality Assessment}

The data quality assessment process is used to determine whether or not the data meet the project data quality objectives. Additional steps of the data quality assessment process may involve data plotting, 
testing for outlying data points, and other statistical analysis relative to the characterization project data quality objectives.

In addition to primary project samples, QA/QC samples will be collected to establish the quantitative and qualitative criteria necessary to describe the acceptability of the data by providing information both comparable to and representative of actual field conditions. QA/QC control samples consisting of field blanks and equipment rinsate blanks will be used to determine filed accuracy. QC (duplicate) samples are used to measure field and laboratory precision. The QA/QC sample results will be evaluated as outlined in the QAPjP (DOE-ID 2004a).

The completeness of the data is the number of samples collected and analyzed compared to the number of samples planned. For this characterization plan, a 90\% completeness objective for all analyses has been established because some sample locations may not contain enough material for all analyses requested.

Precision is a measure of agreement among replicate measurements of the same property. Accuracy is a measure of the closeness of an individual measurement to the true value. Field and laboratory precision and accuracy should be within the limits and goals mentioned in the QAPjP. Data results will be evaluated upon completion of the project to determine whether precision and accuracy goals were met.

\subsubsection{Document Control}

Document control consists of the clear identification of all project-specific documents in an orderly form, secure storage of the clear identification of all project-specific documents in an orderly form, secure storage of all project information, and controlled distribution of all project information. Document control ensures controlled documents of all types related to the project will receive appropriate levels of review, comment, and revision, as necessary.

The project manager is responsible for properly maintaining project documents according to ICP document control requirements. Upon completion of the characterization project, all project documentation and information will be transferred to compliant storage according to project, program, and company requirements. This information may include field logbooks, chain-of-custody forms, laboratory data reports, engineering calculations and drawings, and final technical reports. 


\section{SAMPLING DESIGNATION}

Samples collected will be identified with a unique code and arranged in a sampling and analysis plan table and database. Specific sampling and analysis plan tables will be prepared prior to each sampling event. In an effort to minimize sampling and analysis plan discrepancies, sampling and analysis plan tables will be prepared immediately before each sampling event and the completed sampling and analysis plan tables will be included in the data summary report for each excavation site. The OU 3-13 project manager is responsible for sampling and analysis plan table accuracy.

\subsection{Sample Identification Code}

A systematic character identification code will be used to uniquely identify all samples. Uniqueness is required to maintain consistency and prevent the same identification code from being assigned to more than one sample.

The Sample Management Office (SMO) database will be used to record all pertinent information associated with each sample identification code. Preparation of the plan database and completion of the sample and analysis management request for services are used to initiate the sample and sample waste tracking activities performed by the sample and analysis management.

\subsection{Sampling and Analysis Plan Table/Database}

\subsubsection{General}

A sampling and analysis plan table format was developed to simplify the presentation of the sampling scheme for project personnel. The following sections describe the information that will be recorded in the sampling and analysis plan tables.

\subsubsection{Sample Description Fields}

The sample description fields contain information relating to individual sample characteristics.

5.2.2.1 Sampling Activity. The sampling activity field contains the first six characters of the assigned sample number. The sample number in its entirety will be used to link information from other sources (field data, analytical data, etc.) to the information in the sampling and analysis plan tables for data reporting, sample tracking, and completeness reporting. The analytical laboratory will also use the sample number to track and report analytical results.

5.2.2.2 Sample Type. Data in this field will be selected from the following:

- REG for a regular sample

- QC for a QC sample.

5.2.2.3 Matrix. Data in this field will be selected from the following:

- Soil for soil samples

- Water for QA/QC samples. 
5.2.2.4 Collection Type. Data in this field will be selected from the following:

- $\quad$ GRAB for grab

- $\quad$ COMP for composite

- $\quad$ FBLK for field blanks

- $\quad$ RNST for rinsates

- DUP for duplicate samples.

5.2.2.5 Planned Date. This date is related to the planned sample collection start date.

\subsubsection{Sample Location Fields}

This group of fields pinpoints the exact location for the sample in three-dimensional space, starting with the general AREA, narrowing the focus to an exact location geographically, and then specifying the DEPTH in the depth field.

5.2.3.1 Area. The AREA field identifies the general sample-collection area. The field should contain the standard identifier from the INL area being sampled. For this investigation, samples are being collected from INTEC.

5.2.3.2 Location. This LOCATION field may contain geographical coordinates, $x-y$ coordinates, building numbers, or other location identifying details, as well as program-specific information, such as a borehole or well number. Data in this field will normally be subordinated to the AREA. Samples will be collected from the INTEC area. The LOCATION field identifier will correspond to this site.

5.2.3.3 Type of Location. The TYPE OF LOCATION field supplies descriptive information concerning the exact sample location. Information in this field may overlap that in the LOCATION field, but it is intended to add detail to the location (e.g., native soil).

5.2.3.4 Depth. The DEPTH of a sample location is the distance in feet from surface level or a range in feet from the surface.

\subsubsection{Analysis Type}

5.2.4.1 Analysis Type 1 through 20. The ANALYSIS TYPE (AT) fields indicate analytical types (radiological, chemical, hydrological, etc.). Space necessary to clearly identify each type is provided at the bottom of the form. A standard abbreviation should also be provided, if possible. 


\section{DOCUMENTATION MANAGEMENT AND SAMPLE CONTROL}

The following discussions summarize document management and sample control requirements, as well as sample equipment and handling.

\subsection{Documentation}

The project manager will be responsible for controlling and maintaining all field sampling documents and records and for ensuring that all required documents will be submitted to the ICP Administrative Records and Document Control Office at the conclusion of the project.

Sample documentation, shipping, and custody procedures for this project are based on Environmental Protection Agency-recommended procedures that emphasize careful documentation of sample collection and sample transfer. The appropriate information pertaining to each sample will be recorded in accordance with ICP logbook practices and chain-of-custody procedures and the QAPjP (DOE-ID 2004a). All personnel involved with handling, managing, or disposing of samples will be familiar with ICP handling and shipping sample procedures, and all samples will be dispositioned accordingly.

All information recorded on project field documentation (e.g., logbooks, chain-of-custody forms) will be made in permanent ink. All field documentation errors will be corrected by drawing a single line through the error and entering the correct information; all corrections will be initialed and dated. In addition, photographs will be taken to document the field sampling activities.

\subsubsection{Sample Container Labels}

Waterproof, gummed labels generated from the Integrated Environmental Data Management System database will display information such as the sample identification number, the name of the project, sample location, depth, and requested analysis type. In the field, label information will be completed and placed on the containers before samples are collected. Information concerning sample date, time, preservative used, field measurements of hazards, and the sampler's initials will be recorded during field sampling.

\subsubsection{Field Guidance Forms}

Field guidance forms, provided for each sample location, will be generated from the Integrated Environmental Data Management System database to ensure unique sample numbers. Used to facilitate sample container documentation and organization of field activities, these forms contain information regarding the following:

- $\quad$ Media

- $\quad$ Sample identification numbers

- $\quad$ Sample location

- Aliquot identification

- Analysis type 
- $\quad$ Container size and type

- $\quad$ Sample preservation methods

- $\quad$ Field logbooks.

In accordance with the Administrative Records and Document Control format, field logbooks will be used to record information necessary to interpret the analytical data. All field logbooks will be controlled and managed according to ICP procedures. The field logbooks will be submitted to the project files at the completion of field activities.

6.1.2.1 Sample Logbooks. Sample logbooks used by the field teams will contain such information as the following:

- $\quad$ Physical measurements (if applicable)

- $\quad$ Pertinent information for all QA/QC samples

- $\quad$ Shipping information (e.g., collection dates, shipping dates, destination, and chain-of-custody number).

6.1.2.2 Daily Logbook. A project logbook shall contain a daily summary of the following:

- $\quad$ All team activities

- $\quad$ Problems encountered

- $\quad$ Visitors

- $\quad$ List of work site contacts

- $\quad$ Signature and date, which is entered at the end of each day's sampling activities.

\subsection{Sampling Instructions}

1. Field screening will be performed by non-Environmental Services (ES) personnel as described in the OU 3-13 Group 3, Site CPP-03 Field Sampling Plan (DOE/ID-11246, Section 4.1.2 [DOE-ID 2005]).

2. Downhole gamma logging locations will be installed by non-ES personnel as described in DOE/ID-11246, Section 4.1.2.

3. Material will be collected at selected probe locations by non-ES personnel for counting.

4. The project manager (PM) or job site supervisor (JSS) will use this information to identify probe locations that meet the remediation goals. The above-noted FSP (DOE/ID-11256) states that eight random locations meeting the remediation goals will be selected for ES confirmation sampling. It is expected that the PM will have arranged for these eight (minimum) locations to be surveyed in by subcontractor personnel. It is assumed that the actual sample locations cannot be ascertained until Steps 1-4 above are completed. 
5. Prior to sampling, the project must confirm whether there is adequate information available to work with Packaging \& Transportation (P\&T) to develop a source term to ship samples off-Site. If not, the project must direct ES or others to collect material for on-Site screening.

6. Once a minimum eight sample locations have been identified by the project, a prejob briefing with ES sampling personnel will be set up by the PM or JSS in accordance with MCP-3003. The project will identify any hazard review board personnel and include them in the prejob briefing. The PM or JSS must ensure that this activity is on the facility schedule. The activities specific to this sampling plan will be discussed in the prejob briefing. The project also has the flexibility to add "biased" samples based on field radiological readings. See Step 1 of the JSA in Attachment 1. Note: JSA will be included before sampling operations.

7. If necessary, personnel will obtain a radiological work permit and don any required dosimetry or PPE prior to entering the area of concern. See Step 2 of the JSA in Attachment 1.

8. ES personnel will confirm that the staked marker is the correct grid or biased location as identified by project personnel. This document states that these locations will be clearly marked and surveyed prior to sampling activities. See Step 3 of the JSA in Attachment 1.

9. It is assumed from this document that drillers will stage equipment on the desired location and pull the material from project-designated depths using clean/new equipment between each location/depth. It is assumed that the drillers will hand over a Lexan liner from the appropriate location/depth to ES for processing. The JSS or PM must define how to account for, if necessary, the 11 in. of fill material that was placed over this area and uneven grade/disposition.

10. Project personnel must confirm the sampling approach required for either a grid or a biased location, as applicable. The dimensions of the area to be represented, the depth of the area to be represented, and the sampling approach (grab or composite) have not been defined, so this information must be documented in the sample logbook, based on JSS or PM instruction.

11. As the liner is removed, it is expected that it will be handed over to ES personnel under radiological support supervision for dispensation into a compositing container for mixing. See Step 4 of the JSA in Attachment 1.

12. Samplers should position themselves downwind of the soils being mixed. Mix thoroughly and place material representative of the overall core provided by drillers into each sample container, unless otherwise directed by the JSS. Mix a given core from the randomly selected material, pulling approximately 20-30 proportionate subsamples from the bag into individual sample jars. Place samples that require cooling on ice or put under refrigeration. See Step 4 of the JSA in Attachment 1.

13. Move to the next location and repeat until completed.

14. Collect duplicate as called out in the SAP table. If there is adequate material in the compositing pan from the first core pulled by drillers, it is acceptable to use this material for QC, with the exception that it should be designated in the log notes as a "split" versus a duplicate. If there is inadequate material, drillers should be instructed to pull a second liner from a hole immediately adjacent to the original. See Step 4 of the JSA in Attachment 1. 
15. Collect field blank. To collect a field blank for radionuclide analyses, use certified ultra-pure

J. T. Baker water or equivalent for the liquid in the field during sampling activities. The intent is to measure whether the radiological contaminants of concern are present in the sampling atmosphere. Some of the radionuclides being tested will require nitric acid chemical preservation to $\mathrm{pH}<2$. See field guidance forms or refer to laboratory requirements. See Step 4 of the JSA in Attachment 1.

16. Decontaminate over secondary containment between each location/depth identified for separate sampling collection to ensure that cross-contamination does not occur. If scoops/pans are reused instead of disposed of, a QC rinsate for all analytes called out in Table 4-2 is required. If applicable, following decontamination of the scoop/pan or coring device (as directed by the JSS), ultra-pure water (see Step 16) will be poured over/through the equipment and captured in secondary containment and then poured to the corresponding sample bottles. Some of the analytes will require nitric acid chemical preservation to $\mathrm{pH}<2$. See field guidance forms or refer to laboratory requirements. Any decontamination of sampling equipment will be in compliance with ES decontamination guide (GDE) -162. Any liquid accumulated in the secondary containment will be absorbed onto wipes and added to the other sample waste for the activity. No free liquids will be generated. Note that the drillers must provide clean, new Lexan liners for each core retrieved using the drill rig. See Step 5 of the JSA in Attachment 1.

NOTE: It is possible that tools will not be released as "clean" by Radiological Control, in which case, the tools will be disposed of with all other sampling waste and left at the facility for proper storage/disposal.

17. Clean up the area; bag and label any waste or hand over to the supporting radiological personnel as directed. Handling of waste should be covered in the prejob briefing and the collection and storage of such is directed by the project Waste Generator Services (WGS) representative. See Step 5 of the JSA in Attachment 1.

18. If necessary, submit material to onsite laboratory for screening defined by project. Store other samples pending adequate information to determine appropriate packaging and shipment with WGS, P\&T and Radiological Control support. See Step 7 of the JSA in Attachment 1.

19. After shipment, send a note to the project confirming completion and submit the project file to the Sample and Analysis Management point of contact for records retention.

\subsection{Sample Equipment and Handling}

Analytical samples for laboratory analyses will be collected in pre-cleaned bottles and packaged according to American Society for Testing and Materials or Environmental Protection Agency-recommended procedures. The QA/QC samples will be included to satisfy the QA/QC requirements for the field operation as outlined in the QAPjP (DOE-ID 2004a). Qualified analytical and testing laboratories (approved by sample and analysis management) will analyze these samples.

\subsubsection{Sample Equipment}

Included below is a tentative list of necessary equipment and supplies. This list is as extensive as possible, but not exhaustive, and should only be used as a guide. Other equipment and supplies specified in the project-specific health and safety plan (PLN-2128) is not included in this section. Sampling equipment that would come into contact with sample material will be cleaned prior to use, using an appropriate method (e.g., Alconox or similar non-phosphate soap with deionized water rinse, or equivalent). Field sampling and decontamination supplies may include the following: 
- $\quad$ Stainless steel hand auger

- $\quad$ Power auger

- $\quad$ Tape measure

- Wood stakes and ribbon

- $\quad$ Stainless steel spoons

- $\quad$ Stainless steel or aluminum pans

- $\quad$ Paper wipes

- $\quad$ Plastic garbage bags

- Deionized water

- $\quad$ Non-phosphate-based soap

- $\quad$ Spray bottles

- $\quad$ Aluminum foil

- Hammer

- Tables

- $\quad$ Certified ultra-pure water

- $\quad$ Sample and shipping logbook

- $\quad$ Field Team Leader logbook

- $\quad$ Controlled copies of the FSP, QAPjP, health and safety plan, and applicable referenced procedures

- $\quad$ Black ink pens

- $\quad$ Black ultra-fine markers.

- $\quad$ Sample containers, as specified in the QAPjP

- $\quad$ Preprinted sample labels and field guidance forms

- $\quad$ Nitrile or latex gloves

- $\quad$ Leather work gloves

- $\quad$ Plastic bags

- $\quad$ Custody seals.

Sample preparation and shipping supplies include the following:

- $\quad$ Pipettes

- $\quad \mathrm{pH}$ paper

- $\quad$ Paper wipes

- $\quad$ Parafilm ${ }^{\mathrm{TM}}$

- Clear tape 
- $\quad$ Strapping tape

- $\quad$ Resealable plastic bags in various sizes

- Chain-of-custody forms

- $\quad$ Shipping request forms

- $\quad$ Names, addresses, telephone numbers, and contact names for analytical laboratories

- $\quad$ Task Order Statements of Work for analytical laboratories

- $\quad$ Vermiculite or bubble-wrap (packaging material)

- $\quad$ Blue Ice ${ }^{\mathrm{TM}}$

- Coolers

- "This Side Up" and "Fragile" labels

- $\quad$ Address labels

- $\quad$ Sample bottles and lids

- Custody seals.

\subsubsection{Sample Containers}

Table 6-1 identifies container types, holding times, and preservative requirements that apply to all soil samples being collected under this FSP. Containers will be pre-cleaned (typically certified by the manufacturer) using the appropriate Environmental Protection Agency -recommended cleaning protocols for the bottle type and sample analyses. Extra containers will be available in case of breakage, contamination, or if the need for additional samples arises. Prior to use, preprinted labels with the name of the project, sample identification number, location, depth, and requested analysis will be affixed to the sample containers.

Table 6-2 shows the quality control container types, holding times, and preservative requirements. These analyses apply to rinsate sampling.

\subsubsection{Sample Preservation}

Water samples will be preserved in a manner consistent with the QAPjP (DOE-ID 2004a). If cooling is required for preservation, the temperature will be checked periodically prior to shipment to certify adequate preservation for those samples that require temperatures of $4^{\circ} \mathrm{C}\left(39^{\circ} \mathrm{F}\right)$ for preservation. Ice chests (coolers) containing frozen reusable ice will be used to chill samples in the field after sample collection, if required.

\subsubsection{Chain of Custody}

The ICP chain-of-custody procedures will be followed as well as the requirements in the QAPjP (DOE-ID 2004a). Sample bottles will be stored in a secured area accessible only to the field team members. 
Table 6-1. Sampling bottles, preservation types, and holding times.

\begin{tabular}{|c|c|c|c|}
\hline Analysis & Type & Preservative & Holding Time \\
\hline CLP TAL metals & $\begin{array}{l}\text { Glass or } \\
\text { plastic }\end{array}$ & $4^{\circ} \mathrm{C}$ & $\begin{array}{l}180 \text { days for all metals } \\
\text { except mercury, which is } \\
28 \text { days }\end{array}$ \\
\hline $\begin{array}{l}\text { Appendix IX }{ }^{\mathrm{a}} \text { TAL VOCs (including } \\
\text { acetone, methylene chloride, } \\
\text { 1,1,1-trichloroethane, tetrachloroethene, } \\
\text { and trichloroethylene) }\end{array}$ & Glass & $4^{\circ} \mathrm{C}$ & 14 days \\
\hline Appendix IX ${ }^{\mathrm{a}}$ TAL SVOCs & Glass & $4^{\circ} \mathrm{C}$ & 14 days \\
\hline PCBs & Glass & $4^{\circ} \mathrm{C}$ & 14 days \\
\hline $\begin{array}{l}\text { Alpha radionuclides } \\
(\mathrm{Am}-241, \mathrm{Pu}-238, \mathrm{Pu}-239 / 240 \text {, } \\
\text { Uranium, } \mathrm{Np}-237)\end{array}$ & $\begin{array}{l}\text { High-density } \\
\text { polyethylene }\end{array}$ & NA & 180 days for all isotopes \\
\hline $\begin{array}{l}\text { Beta radionuclides } \\
(\mathrm{Pu}-241, \mathrm{Sr}-90, \mathrm{H}-3, \mathrm{I}-129, \mathrm{Tc}-99)\end{array}$ & $\begin{array}{l}\text { High-density } \\
\text { polyethylene }\end{array}$ & NA & $\begin{array}{l}180 \text { days for all isotopes } \\
\text { except } \mathrm{I}-129, \text { which is } \\
28 \text { days }\end{array}$ \\
\hline $\begin{array}{l}\text { Gamma emitters } \\
\text { (Cs-137, Eu-152, Eu-154) }\end{array}$ & $\begin{array}{l}\text { High-density } \\
\text { polyethylene }\end{array}$ & NA & 180 days for all isotopes \\
\hline \multicolumn{4}{|l|}{ a. 40 CFR 264.} \\
\hline $\begin{array}{l}\text { CFR }=\text { Code of Federal Regulations } \\
\text { CLP }=\text { Contract Laboratory Program } \\
\text { NA }=\text { not applicable } \\
\text { PCB }=\text { polychlorinated biphenyl } \\
\text { SVOC }=\text { semivolatile organic compound } \\
\text { TAL }=\text { target analyte list } \\
\text { VOC }=\text { volatile organic compound }\end{array}$ & & & \\
\hline
\end{tabular}


Table 6-2. Quality control liquids sampling bottles, preservation types, and holding times.

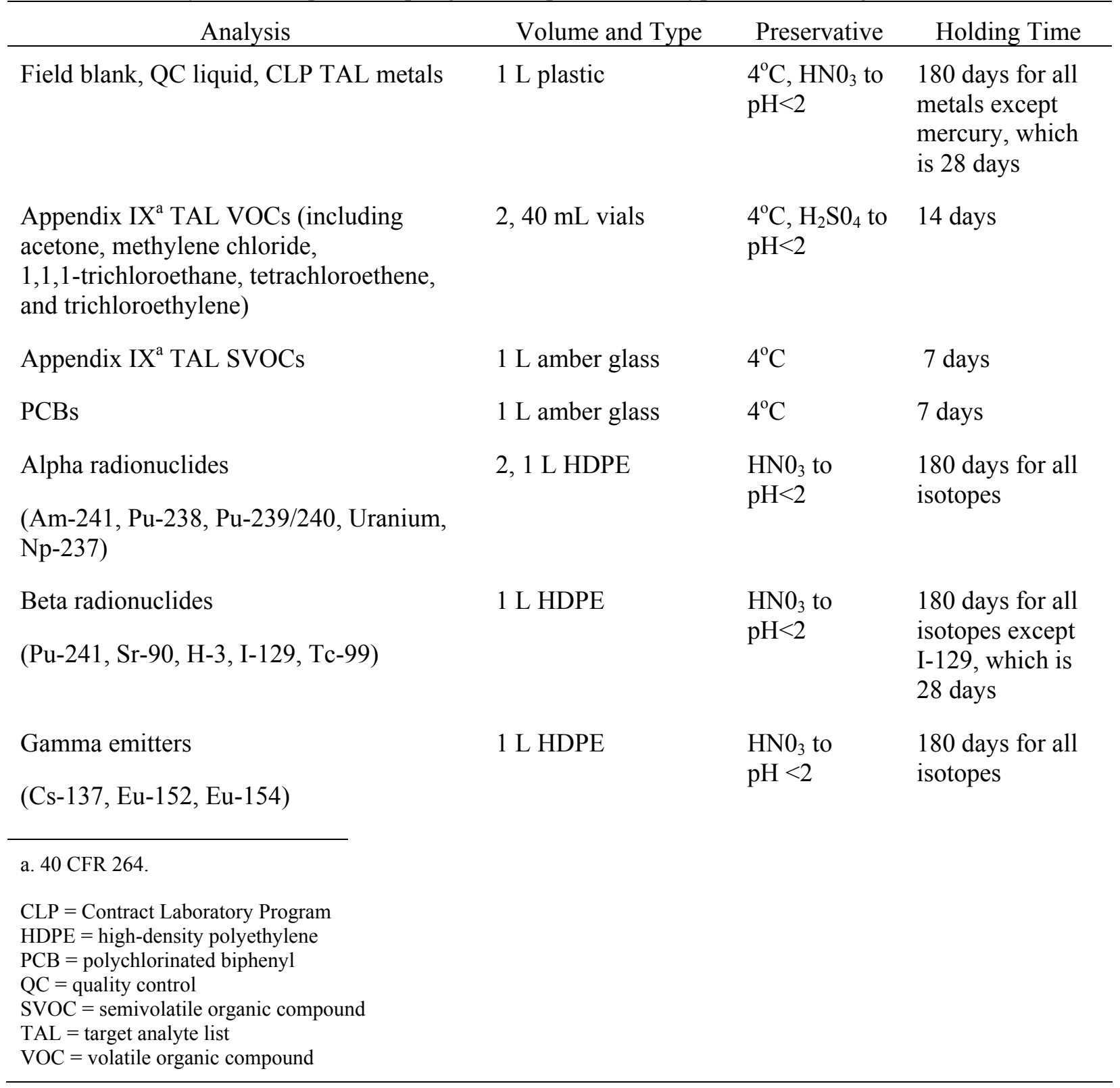

\subsubsection{Transportation of Samples}

Samples will be shipped in accordance with the regulations issued by Department of Transportation (49 CFR Parts 171 through 178) and Environmental Protection Agency sample handling, packaging, and shipping methods (40 CFR 262.11). All samples will be packaged in accordance with ICP packaging and transportation chain-of-custody and sample labeling procedures.

6.3.5.1 Custody Seals. Custody seals will be placed on all shipping containers to ensure that tampering or unauthorized opening will not compromise sample integrity. The seal will be attached in such a way that opening the container requires the seal to be broken. Clear plastic tape will be placed 
over the seals to ensure that the seals are not damaged during shipment. Seals will be affixed to containers before the samples leave the custody of the sampling personnel.

6.3.5.2 On-Site and Off-Site Shipping. An on-Site shipment is any transfer of material within the perimeter of the INL. Site-specific requirements for transporting samples within Site boundaries and those required by the shipping/receiving department will be followed. Shipment within the INL boundaries will conform to Department of Transportation requirements as stated in 49 CFR 171 through 49 CFR 178. Off-Site sample shipments will be coordinated with ICP Packaging and Transportation personnel, as necessary, and will conform to all applicable Department of Transportation requirements.

\subsection{Documentation Revision Requests}

Revisions to this document will follow ICP document control procedures. 
6-10 


\section{HEALTH AND SAFETY}

Health and Safety issues will be addressed in the Miscellaneous Sites Health and Safety Plan (PLN-2128). 


\section{REFERENCES}

40 CFR 136, 2003, "Guidelines for Establishing Test Procedures for the Analysis of Pollutants," Code of Federal Regulations, Office of the Federal Register, September 2003.

40 CFR 136, Appendix B, 2006, "Definition and Procedure for the Determination of the Method Detection Limit—Revision 1.11," Code of Federal Regulations, Office of the Federal Register, June 2006.

40 CFR 262.11, 2002, "Hazardous Waste Determination," Code of Federal Regulations, Office of the Federal Register, July 2002.

40 CFR 264, 2006, "Standards for Owners and Operators of Hazardous Waste Treatment, Storage, and Disposal Facilities," Code of Federal Regulations, Office of the Federal Register, May 2006.

49 CFR 171, 2006, “General Information, Regulations, and Definitions," Code of Federal Regulations, Office of the Federal Register, June 2006.

49 CFR 172, 2006, "Hazardous Materials Table, Special Provisions, Hazardous Materials Communications, Emergency Response Information, and Training Requirements," Code of Federal Regulations, Office of the Federal Register, June 2006.

49 CFR 173, 2006, "Shippers-General Requirements for Shipments and Packagings," Code of Federal Regulations, Office of the Federal Register, June 2006.

49 CFR 174, 2006, "Carriage by Rail," Code of Federal Regulations, Office of the Federal Register, January 2006.

49 CFR 175, 2006, "Carriage by Aircraft," Code of Federal Regulations, Office of the Federal Register, June 2006.

49 CFR 176, 2006, "Carriage by Vessel," Code of Federal Regulations, Office of the Federal Register, January 2006.

49 CFR 177, 2006, "Carriage by Public Highway," Code of Federal Regulations, Office of the Federal Register, January 2006.

49 CFR 178, 2006, "Specifications for Packagings," Code of Federal Regulations, Office of the Federal Register, June 2006.

42 USC $\S 6901$ et seq., 1976, "Resource Conservation and Recovery Act of 1976," United States Code, October 21, 1976. (The 1980 Amendment is cited as the "Solid Waste Disposal Act Amendments of 1980.")

42 USC § 9601 et seq., 1980, “Comprehensive Environmental Response, Compensation and Liability Act of 1980 (CERCLA/Superfund)," United States Code, December 11, 1980.

DOE-ID, 1991, Federal Facility Agreement and Consent Order for the Idaho National Engineering Laboratory, Administrative Record No. 1088-06-29-120, U.S. Department of Energy Idaho Operations Office; U.S. Environmental Protection Agency, Region 10; Idaho Department of Health and Welfare, December 4, 1991. 
DOE-ID, 1999, Final Record of Decision, Idaho Nuclear Technology and Engineering Center, Operable Unit 3-13, DOE/ID-10660, Rev. 0, U.S. Department of Energy Idaho Operations Office, October 1999.

DOE-ID, 2004a, Quality Assurance Project Plan for Waste Area Groups 1, 2, 3, 4, 5, 6, 7, 10 and Inactive Sites, DOE/ID-10587, Rev. 7, U.S. Department of Energy Idaho Operations Office, March 2004.

DOE-ID, 2005, Operable Unit 3-13, Group 3, Site CPP-03 Field Sampling Plan, Rev. 0, U.S. Department of Energy Idaho Operations Office, October 2005.

DOE-ID, 2006a, Operable Unit 3-13, Group 3, Other Surface Soils Remediation Sets 4-6 (Phase II) Remedial Design/Remedial Action Work Plan, DOE/ID-11254, Rev. 0, U.S. Department of Energy Idaho Operations Office, July 2006.

DOE-ID, 2006b, Operable Unit 3-13, Group 3, Other Surface Soils Remediation Sets 4-6 (Phase II) Waste Management Plan, DOE/ID-11258, Rev. 0, U.S. Department of Energy Idaho Operations Office, July 2006.

EPA, 1983, Methods for the Chemical Analysis of Water and Wastes, EPA/600/4-79-020, U.S. Environmental Protection Agency, March 1983.

EPA, 1987, A Compendium of Superfund Field Operations Methods, EPA/540-P-87/001, U.S. Environmental Protection Agency, December 1987.

EPA, 1988, Guidance for Conducting Remedial Investigations and Feasibility Studies Under CERCLA, Interim Final, EPA/540/G-89/004, U.S. Environmental Protection Agency, October 1988.

EPA, 1989, Methods for Evaluating the Attainment of Cleanup Standards, Volume I: Soils and Solid Media, EPA/230/02-89/042, U.S. Environmental Protection Agency, February 1989.

EPA, 1991a, Soil Sampling and Analysis for Volatile Organic Compounds, EPA/540/4-91/001, U.S. Environmental Protection Agency, February 1991.

EPA, 1991b, Characterizing Soils for Hazardous Waste Site Assessments, EPA/540/4-91/003, U.S. Environmental Protection Agency, March 1991.

EPA, 1993, Statement of Work for Inorganic Analysis-Multimedia, Multi-Concentration, ILMO3.0, U.S. Environmental Protection Agency, 1993.

EPA, 1994, Statement of Work for Organic Analysis-Multimedia, Multi-Concentration, OLM03.0, U.S. Environmental Protection Agency, May 1999.

EPA, 1996, Test Methods for Evaluating Solid Waste, Physical/Chemical Methods, SW-846, U.S. Environmental Protection Agency, 1996.

EPA, 2006, Guidance on Systematic Planning Using the Data Quality Objective Process, EPA QA/G-4, U.S. Environmental Protection Agency, February 2006. 
ER-SOW-394, 2004, "Idaho National Engineering and Environmental Laboratory Sample and Analysis Management Statement of Work for Analytical Services,” Rev. 2, Idaho National Engineering and Environmental Laboratory, May 2004.

FEMP, 2001, Calibration of NaI In Situ Gamma Spectroscopy Systems, Fernald Environmental Management Project, 20310-RP-0006, Rev. 0, March 2001.

GDE-162, 2004, “Decontaminating Sample Equipment,” Rev. 1, Idaho Completion Project, April 2004.

INEL, 1996, Background Dose Equivalent Rates and Surficial Soil Metal and Radionuclide Concentrations for the Idaho National Engineering Laboratory, INEL-94/0250, Rev. 1, Idaho National Engineering and Environmental Laboratory, August 1996.

MCP-1394, 2005, “Managing Hazardous Samples,” Idaho Completion Project, September 2005.

MCP-3003, 2005, "Performing Pre-Job Briefings and Documenting Feedback," Rev. 13, Manual 9Operations, Idaho Completion Project, March 2005.

MCP-9228, 2005, “Managing Nonhazardous Samples,” Idaho Completion Project, September 2005.

PLN-524, 2005, "Quality Assurance Project Plan for Environmental Services Characterization Sampling," Rev. 4, Idaho Completion Project, August 2005.

PLN-2128, 2006, "Miscellaneous Sites Cleanup Project Health, Safety, and Work Control Plan,” Rev. 0 Draft, Idaho Cleanup Project, June 2006. 
Appendix A

Group 3, Phase II Sites with Contaminants of Concern Exceeding Remediation Goals 


$$
\text { A-2 }
$$




\section{Appendix A}

\section{OU 3-13 Phase II Sites with Contaminants of Concern Exceeding Remediation Goals}

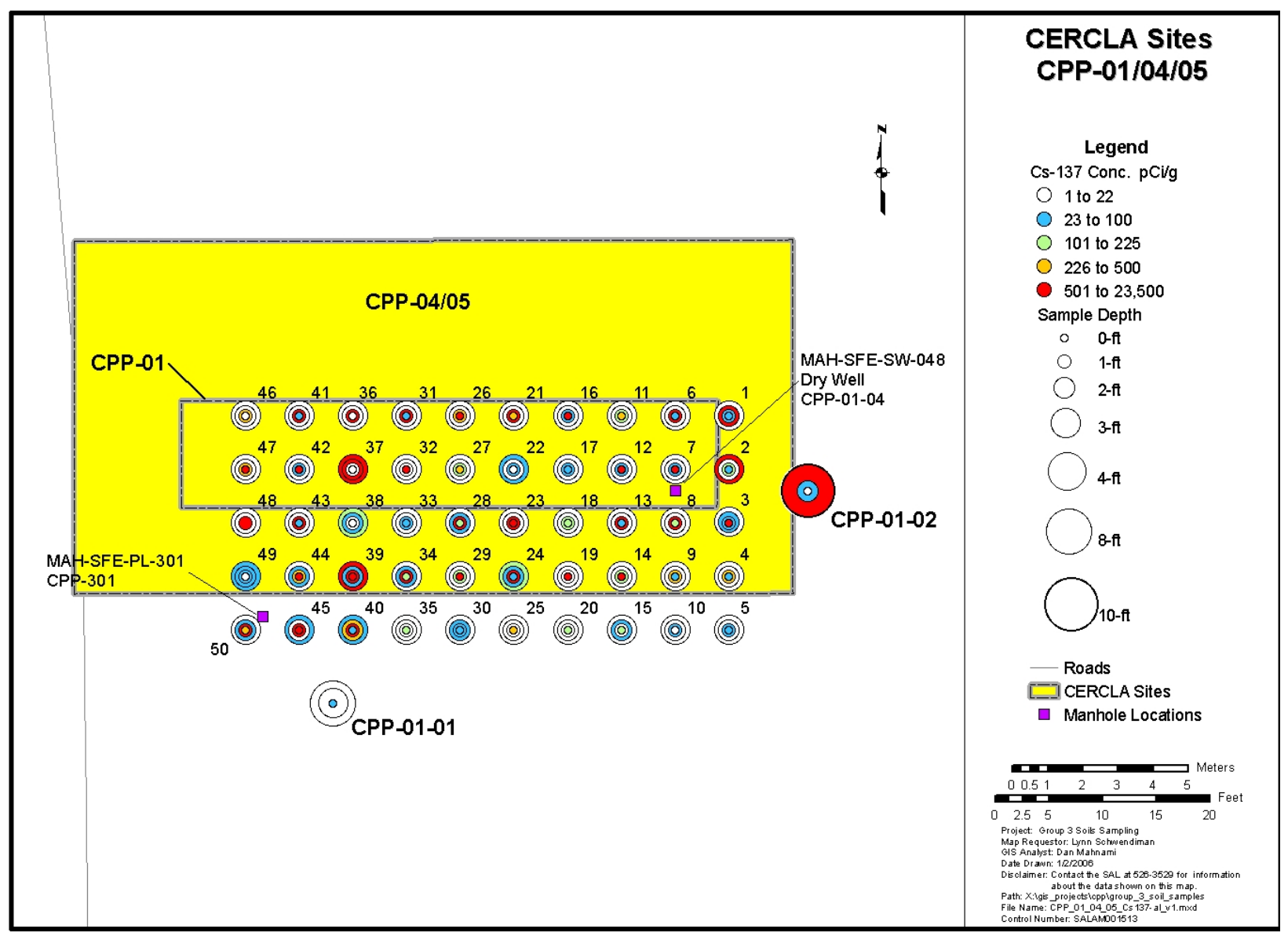

Figure A-1. CPP-01, -04, -05 Cs-137. 


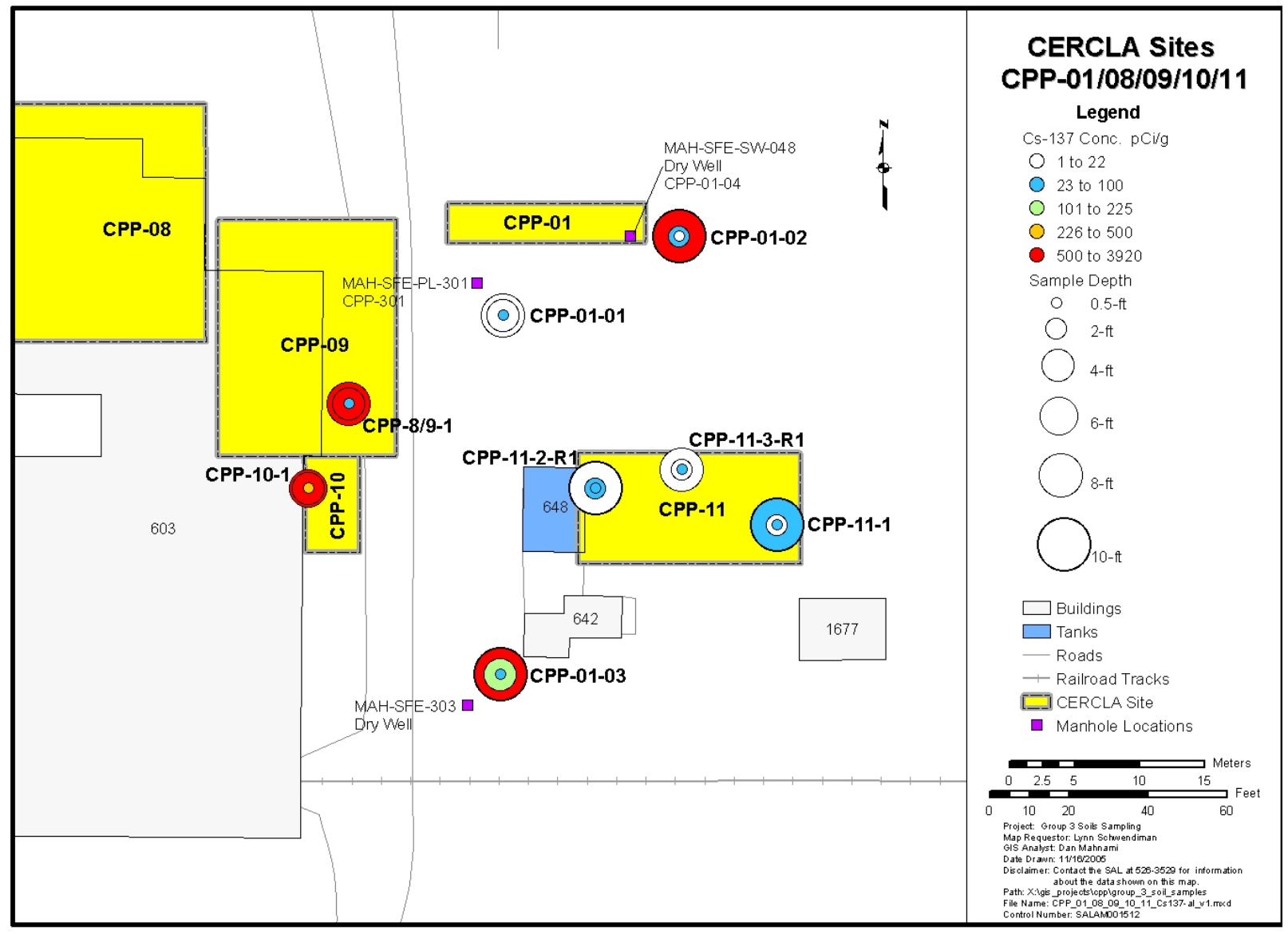

Figure A-2. CPP-01, -08, -09, -10, -11 Cs-137. 


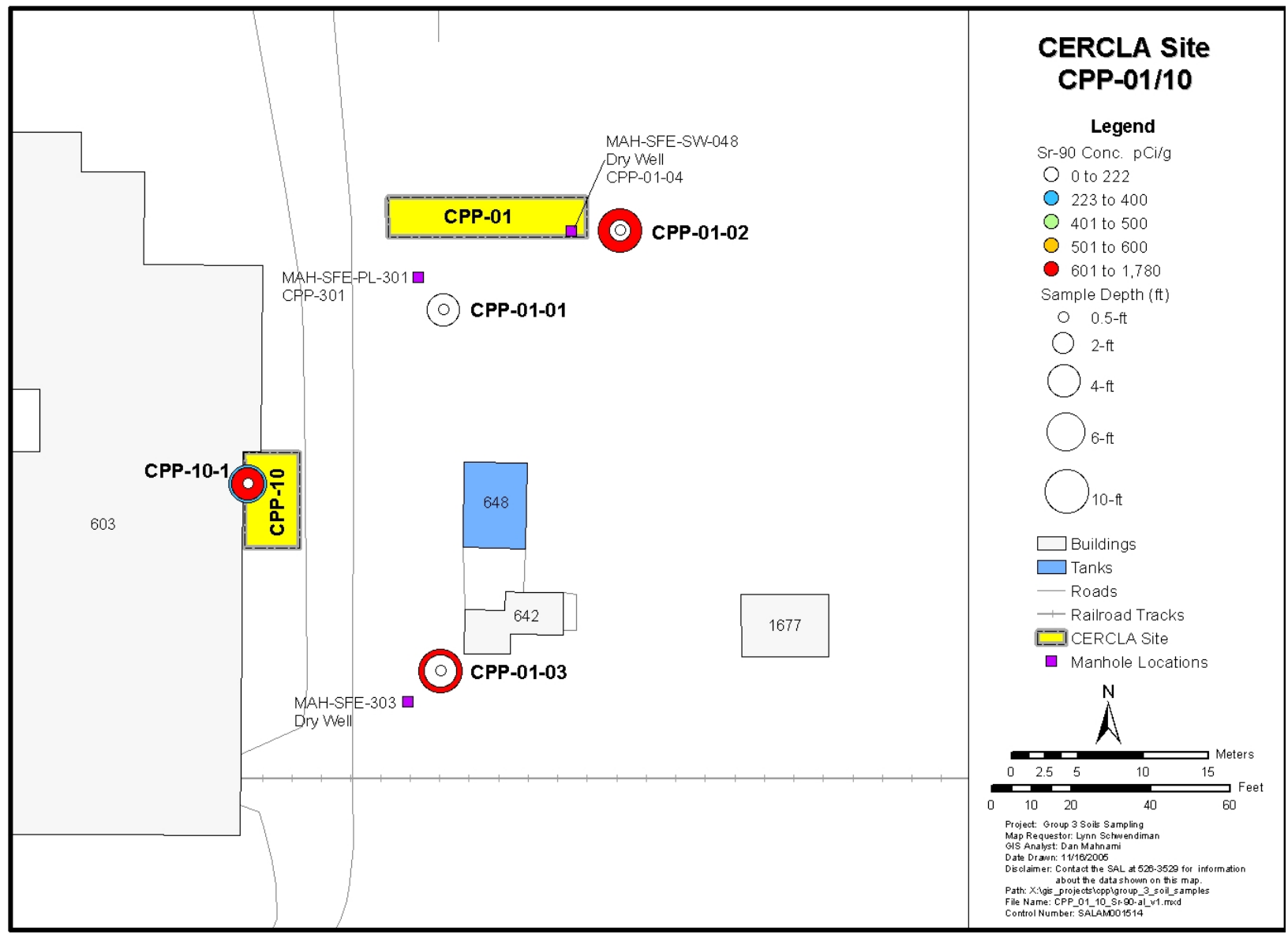

Figure A-3. CPP-01, -10 Sr-90. 


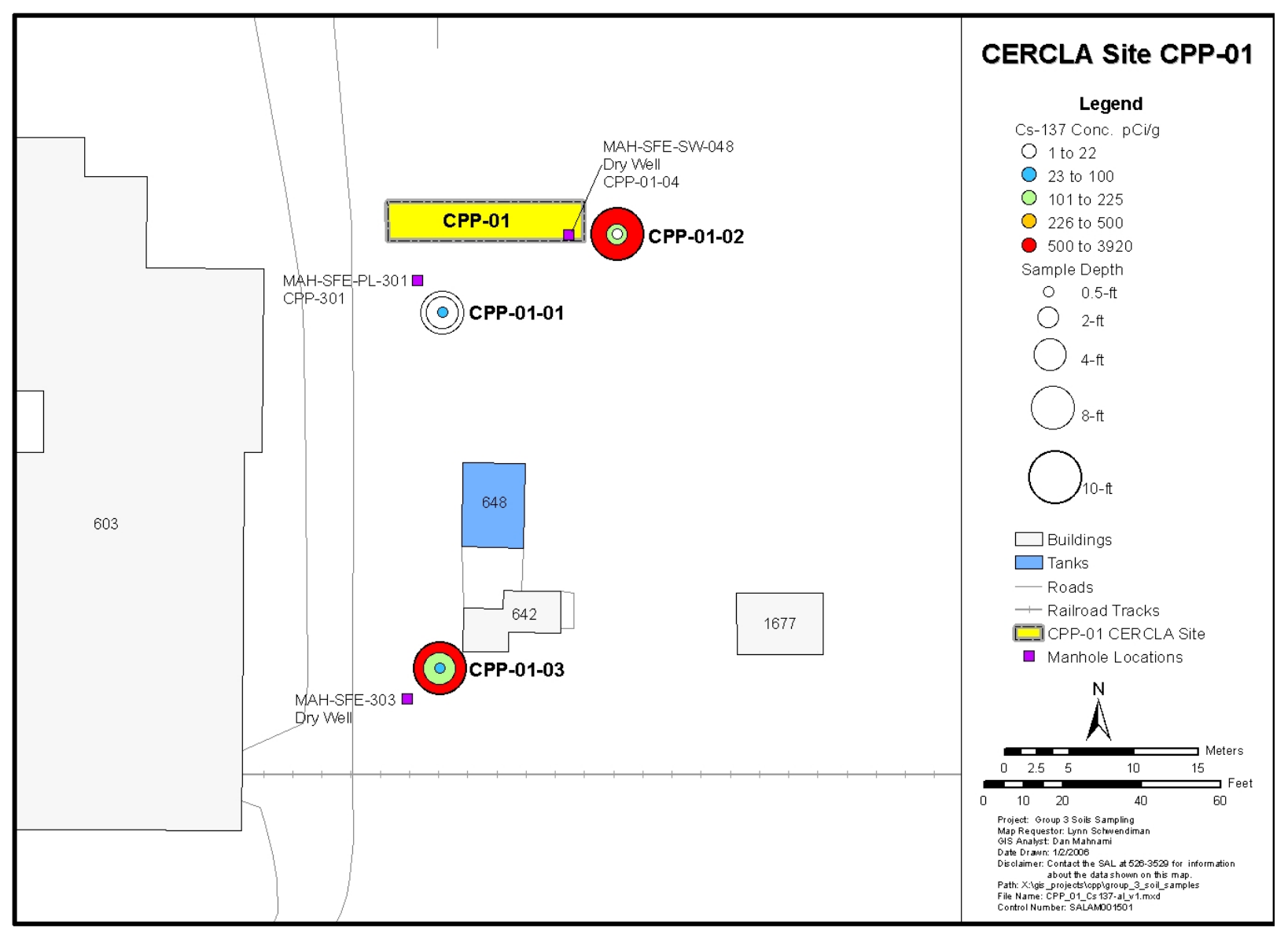

Figure A-4. CPP-01 Cs-137. 


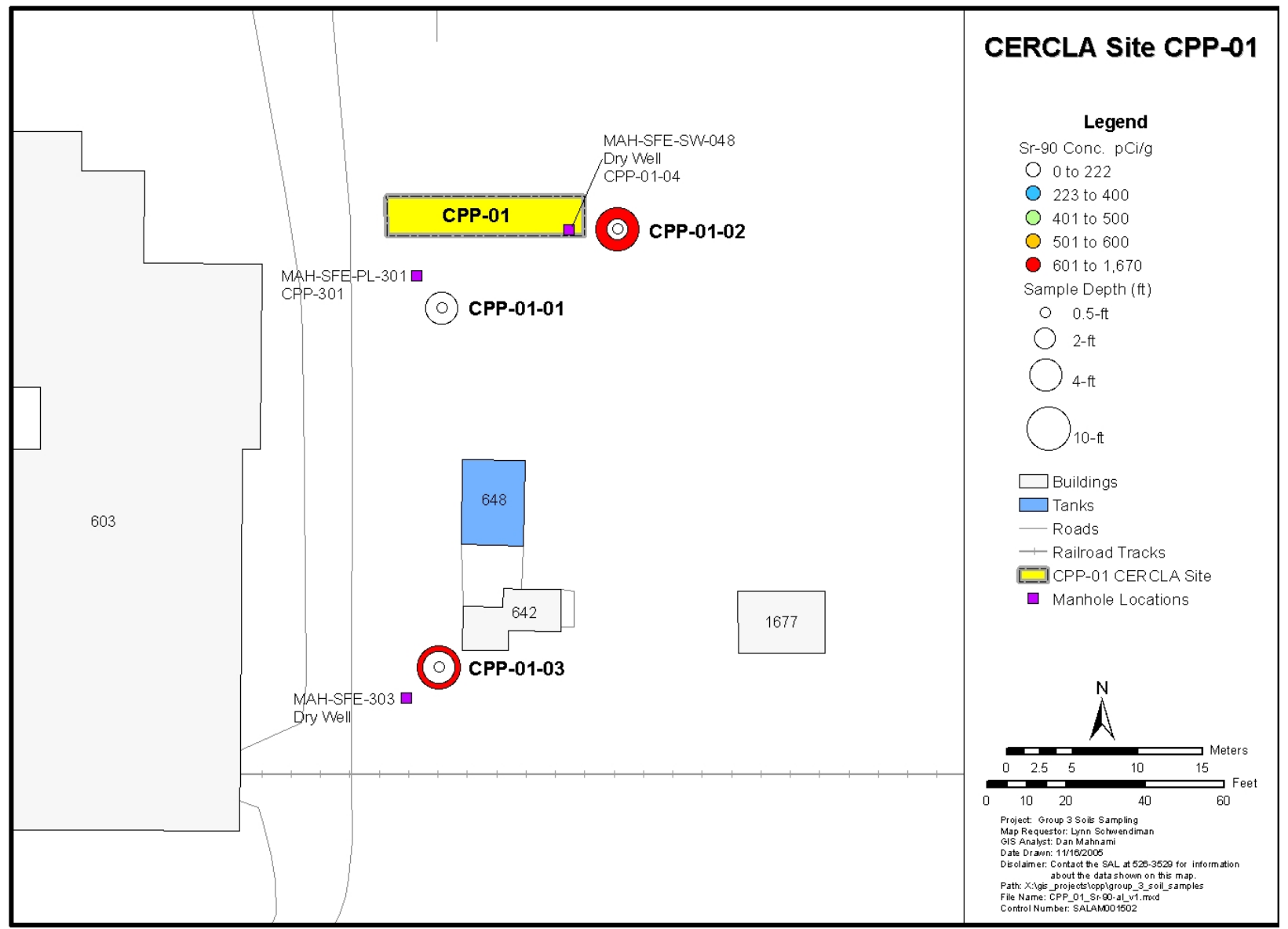

Figure A-5. CPP-01 Sr-90. 


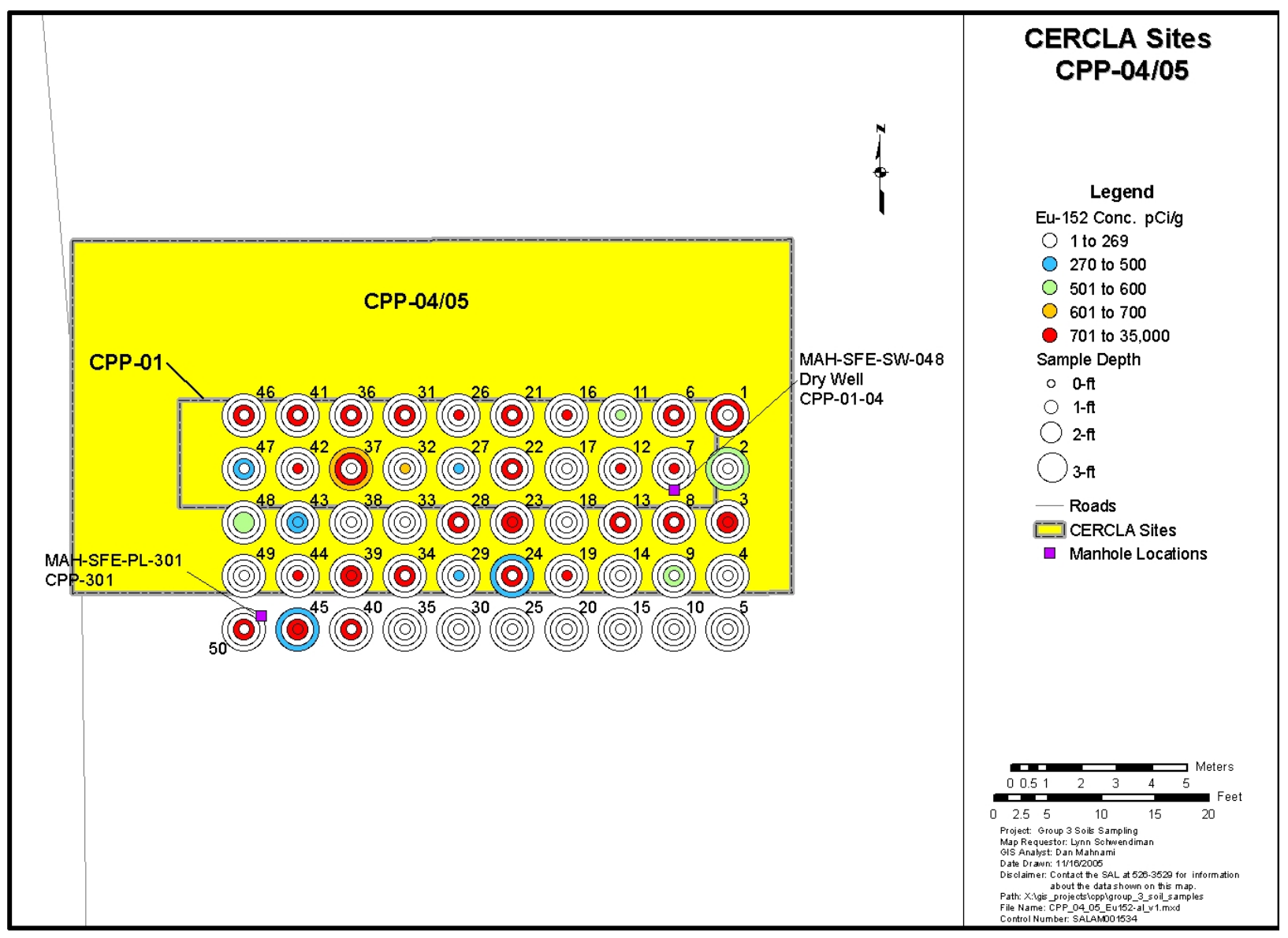

Figure A-6. CPP-04, -05 Eu-152. 


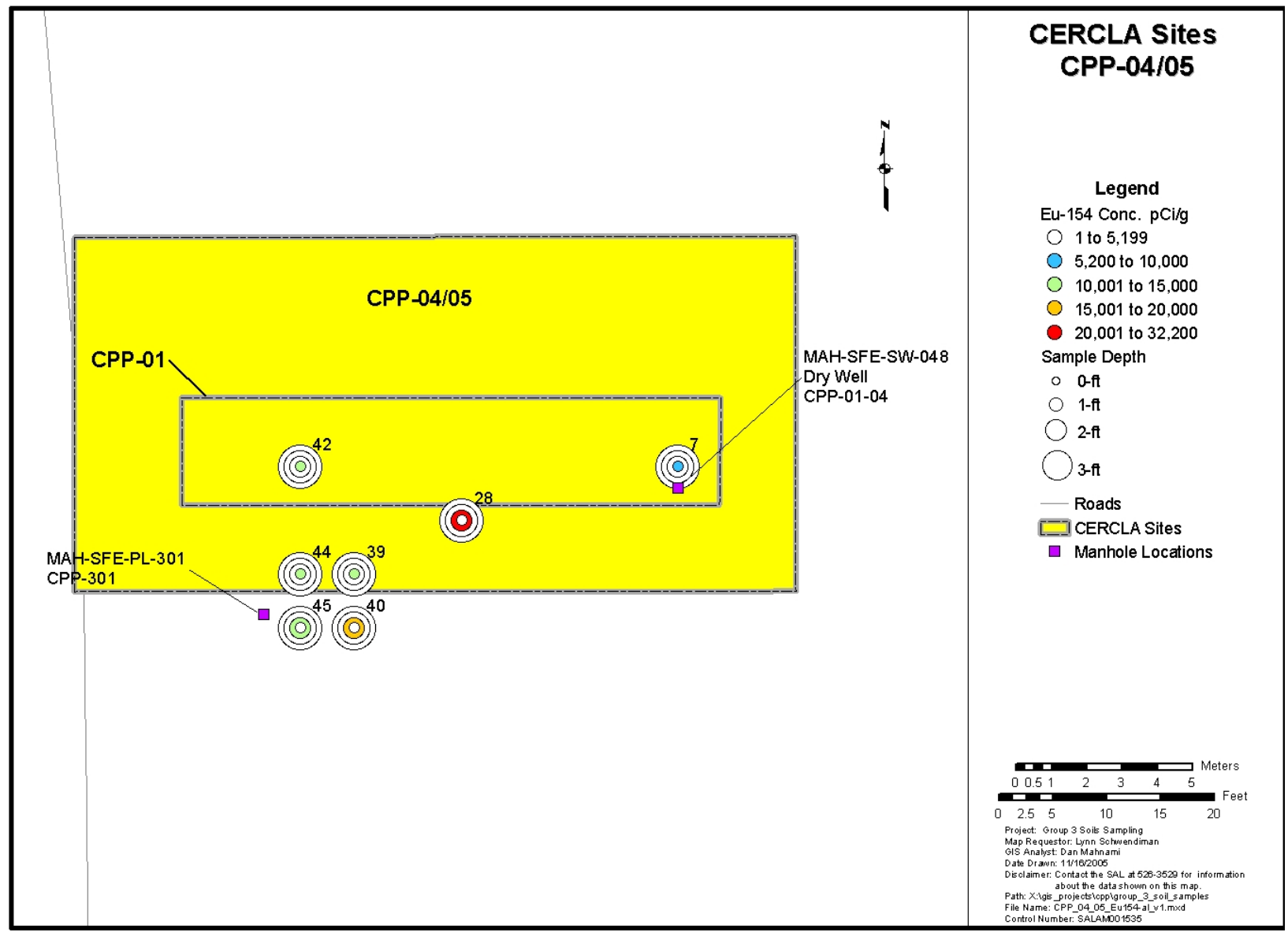

Figure A-7. CPP-04, -05 Eu-154. 


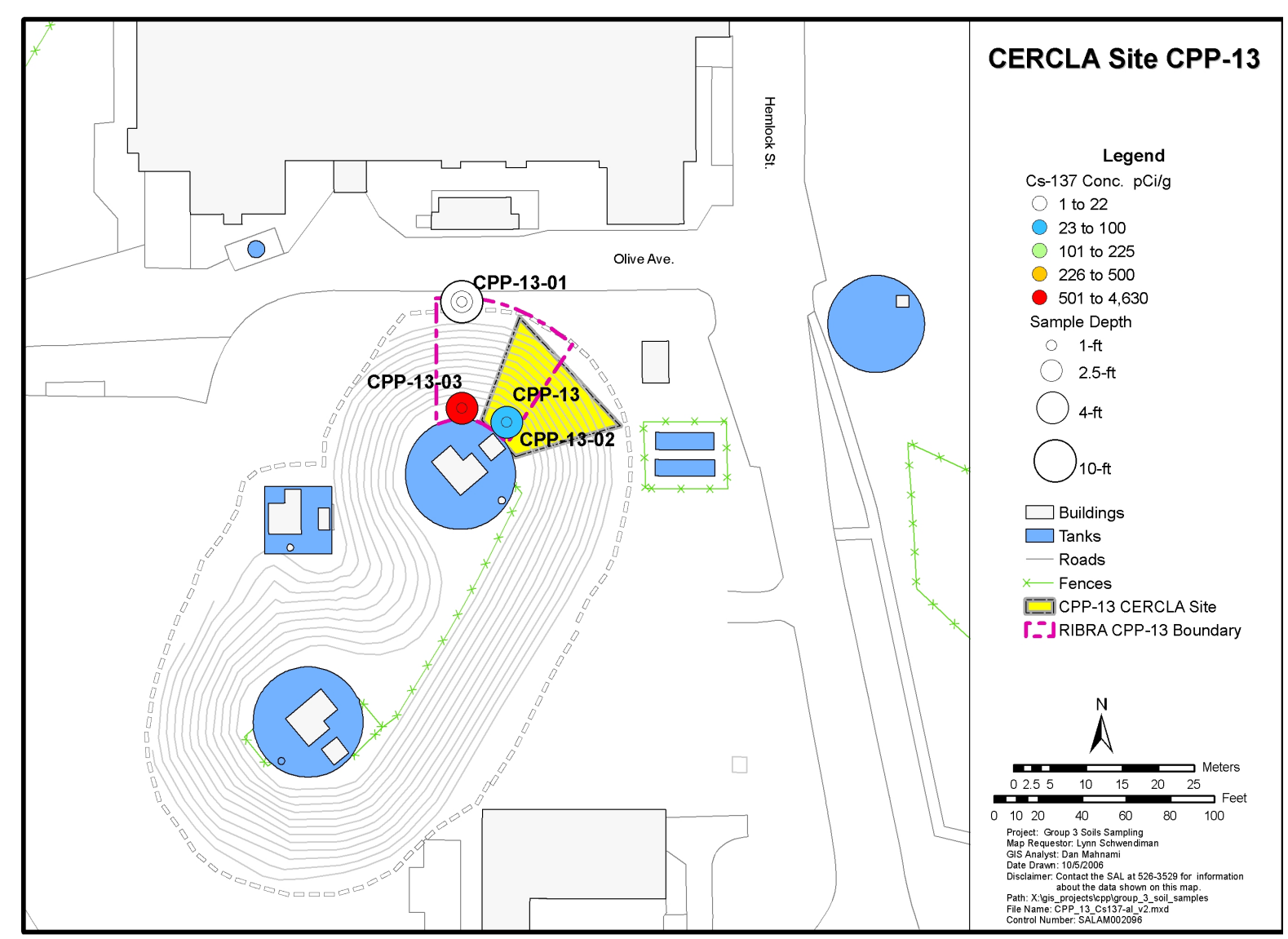

Figure A-8. CPP-13 Cs-37. 


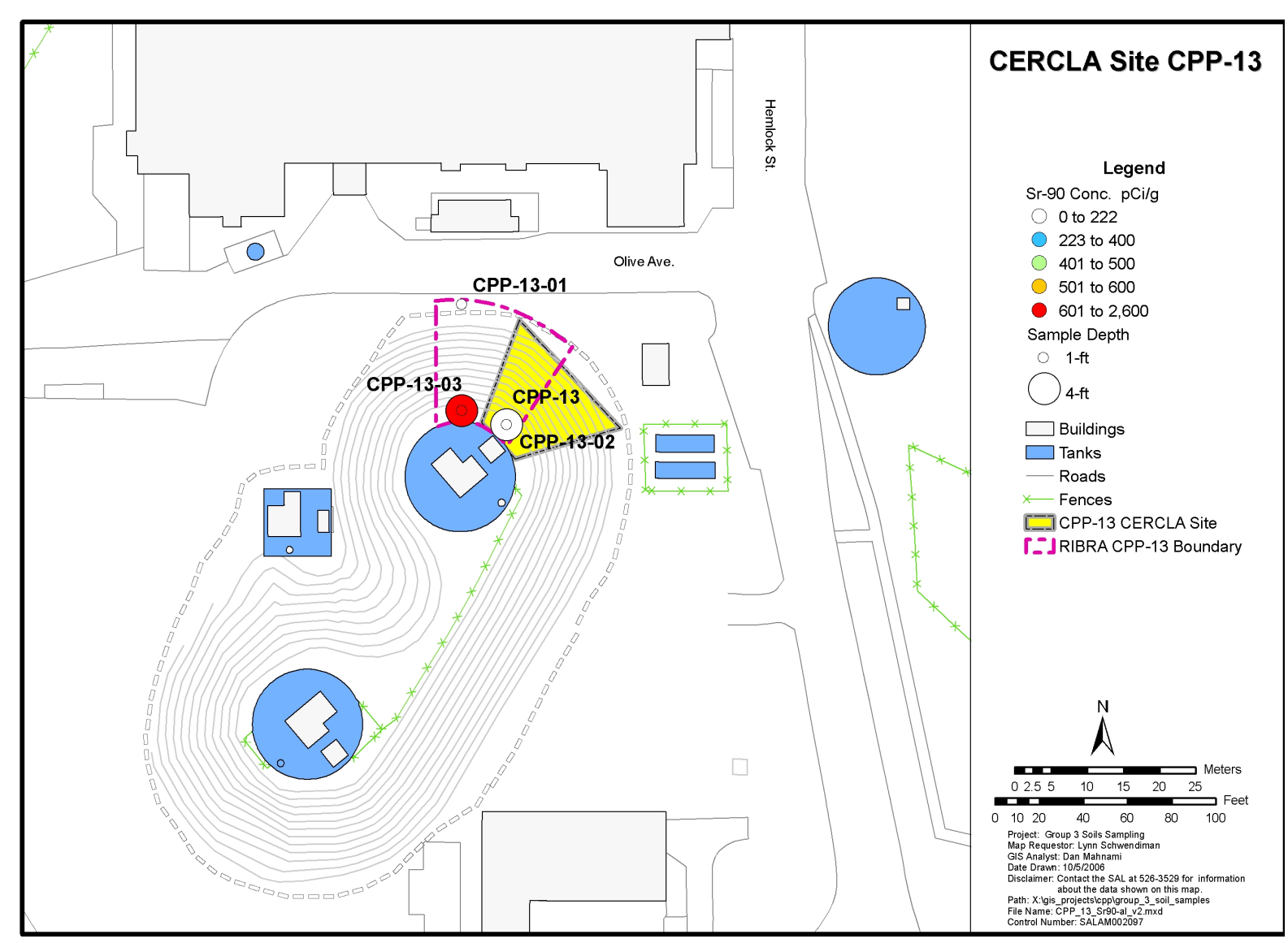

Figure A-9. CPP-13 Sr-90. 


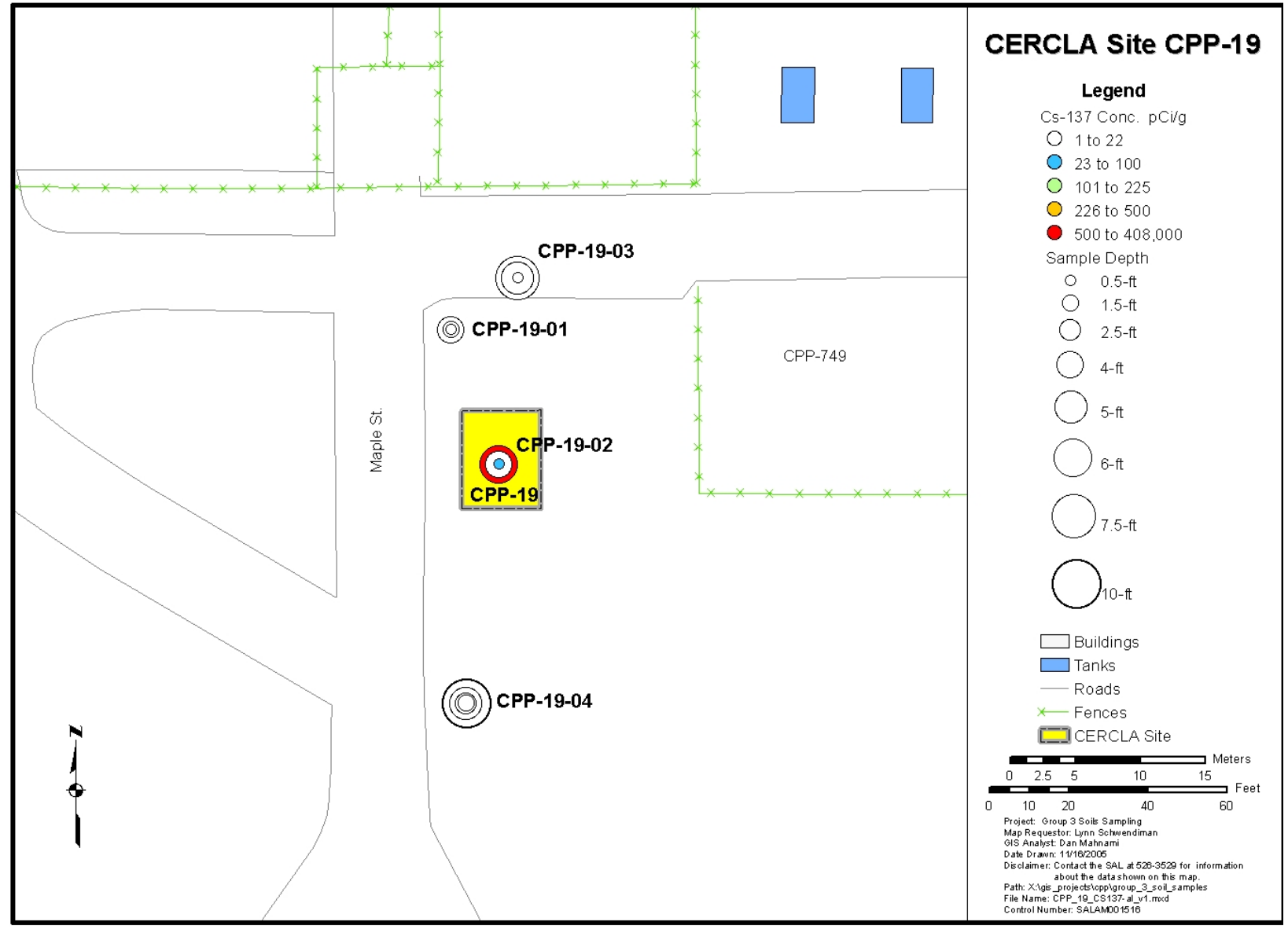

Figure A-10. CPP-19 Cs-137. 


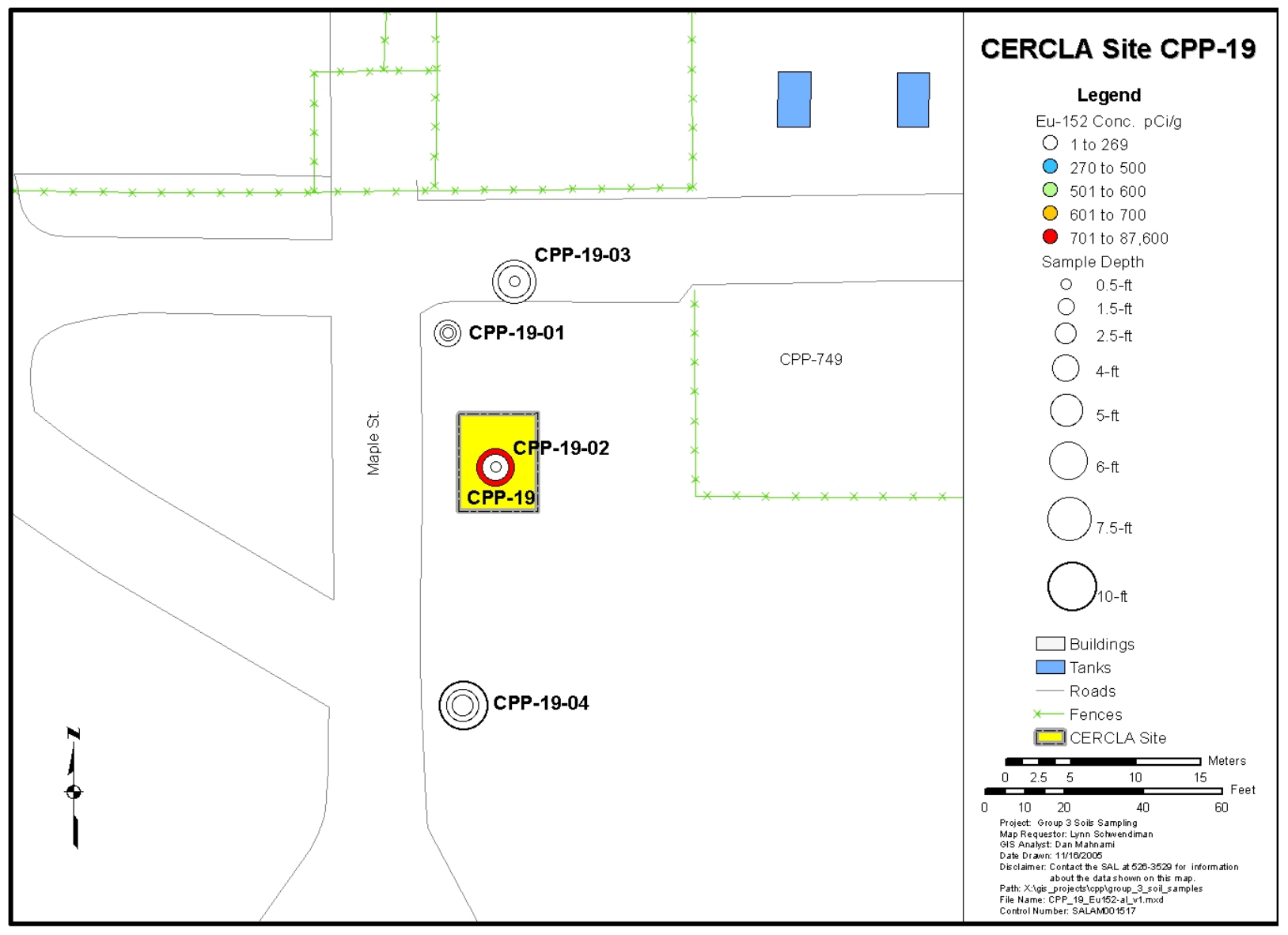

Figure A-11. CPP-19 Eu-152. 


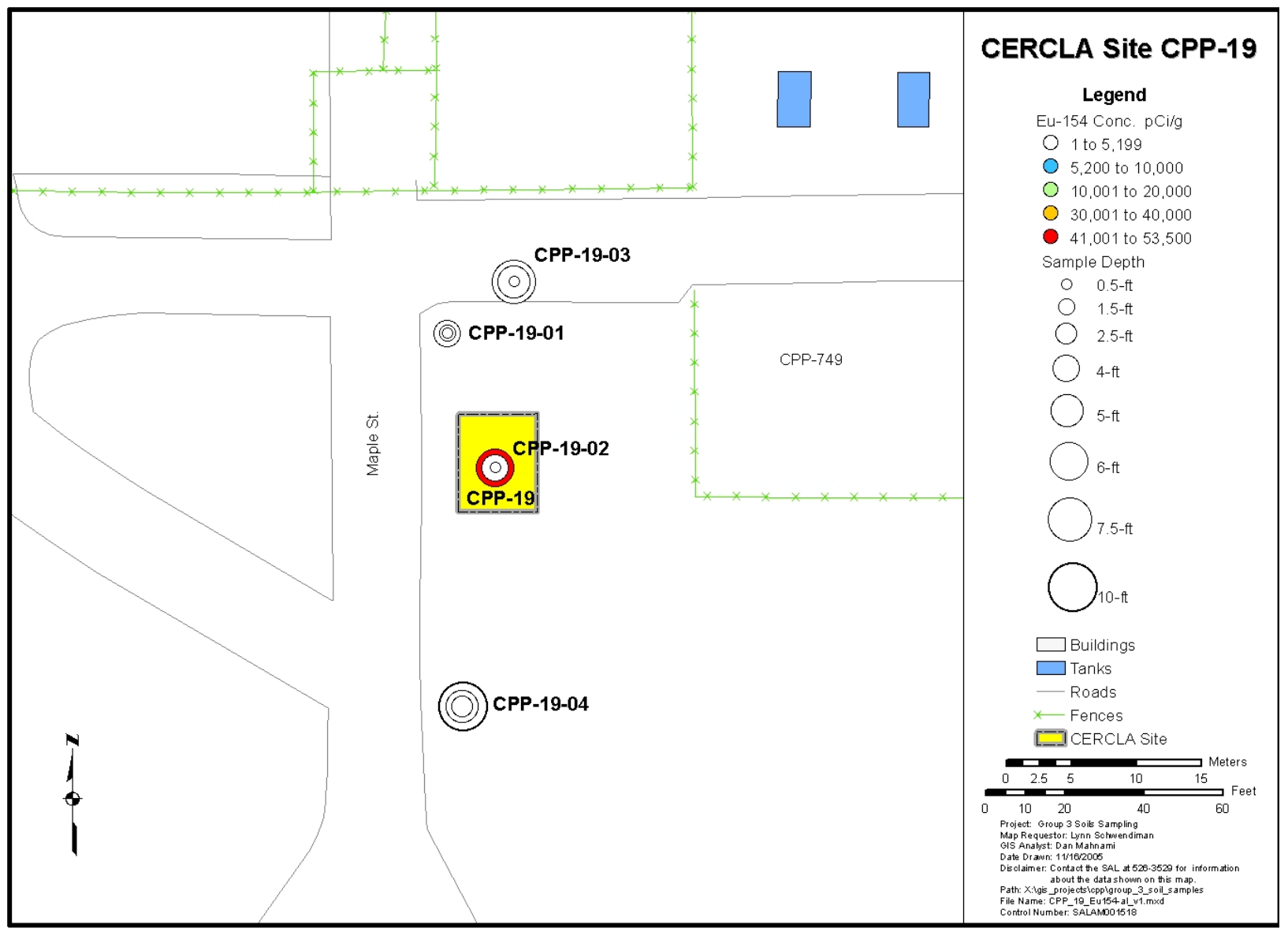

Figure A-12. CPP-19 Eu-154. 


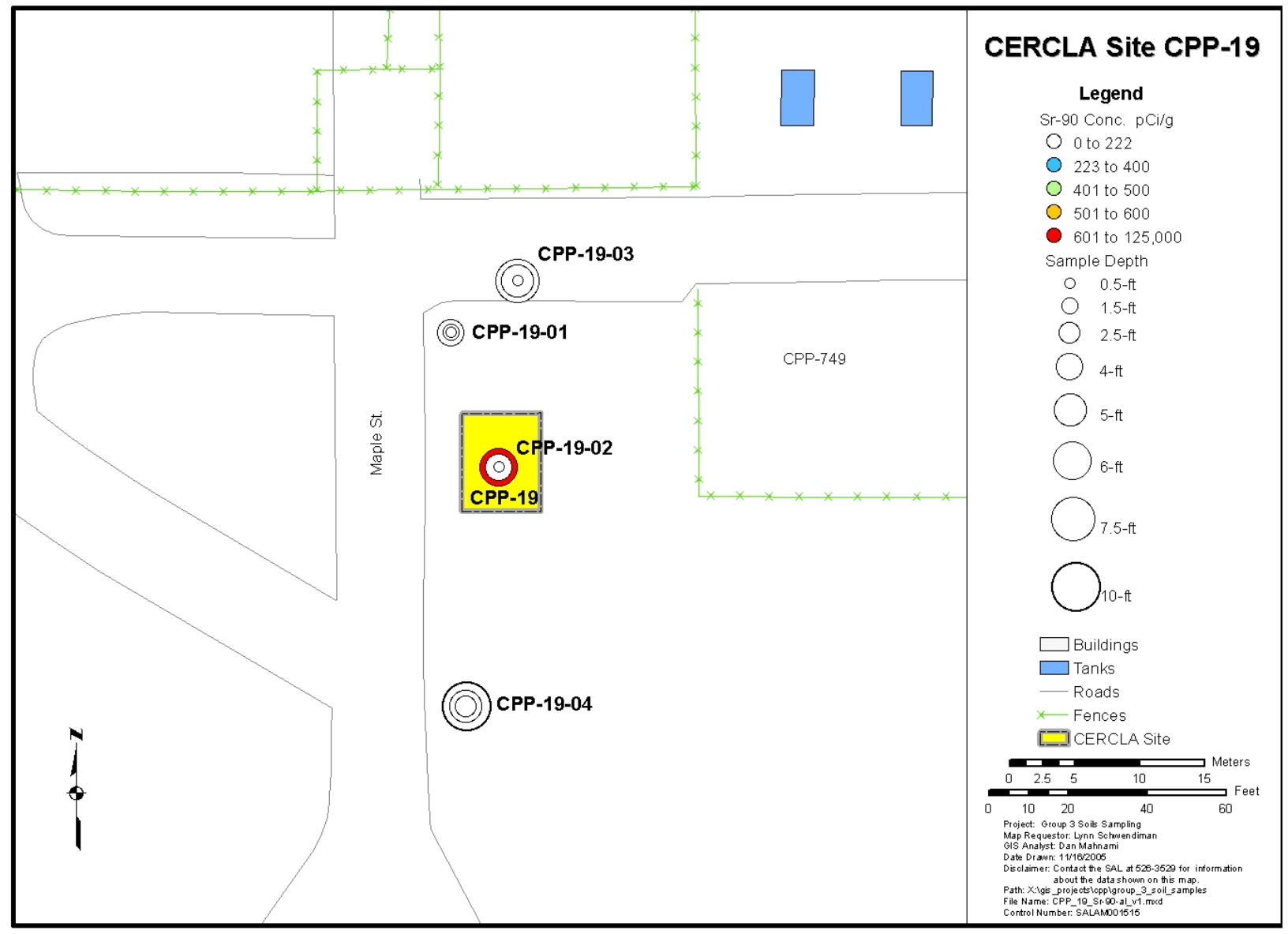

Figure A-13. CPP-19 Sr-90. 


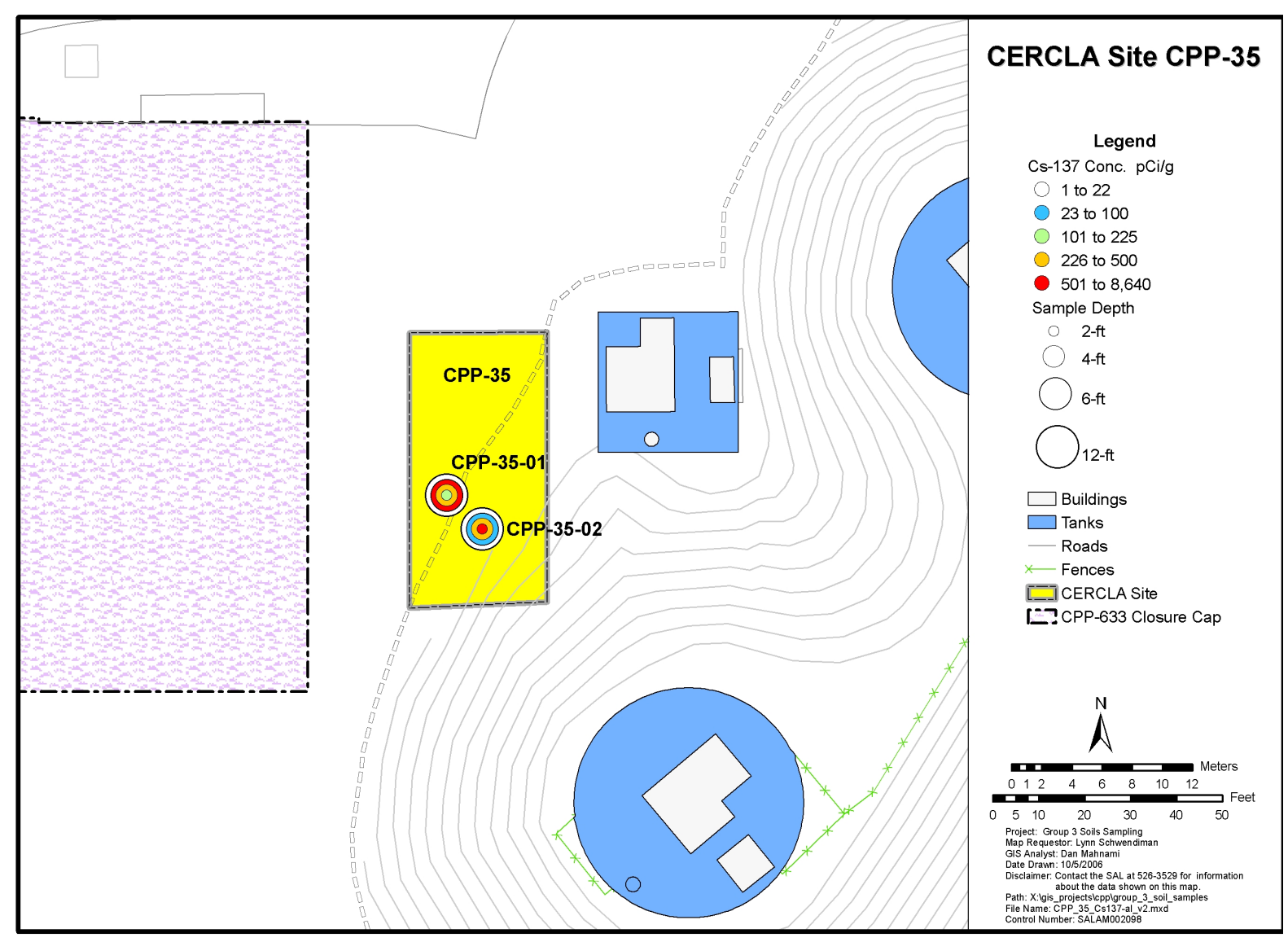

Figure A-14. CPP-35 Cs-37. 


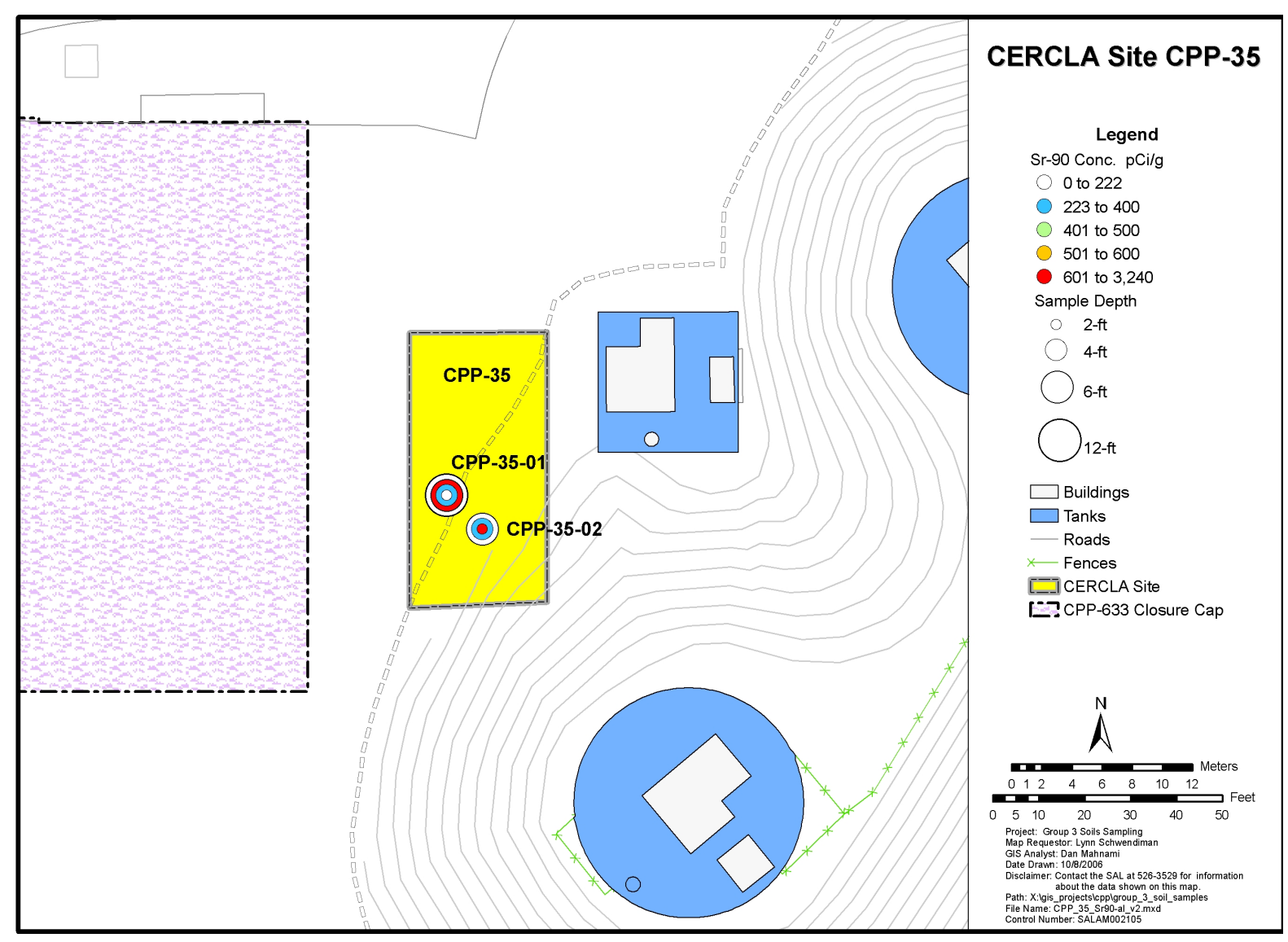

Figure A-15. CPP-35 Sr-90 


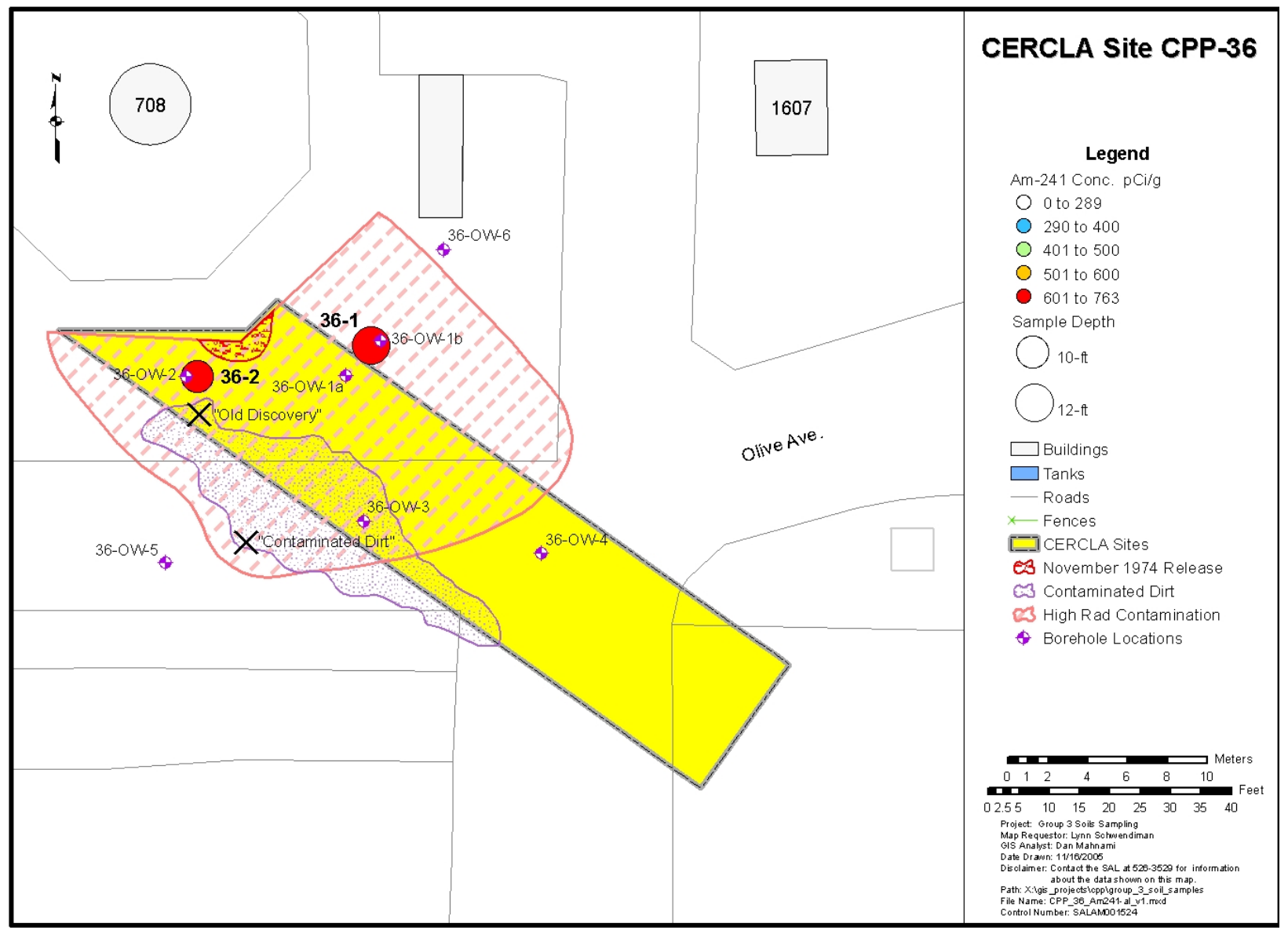

Figure A-16. CPP-36 Am-241. 


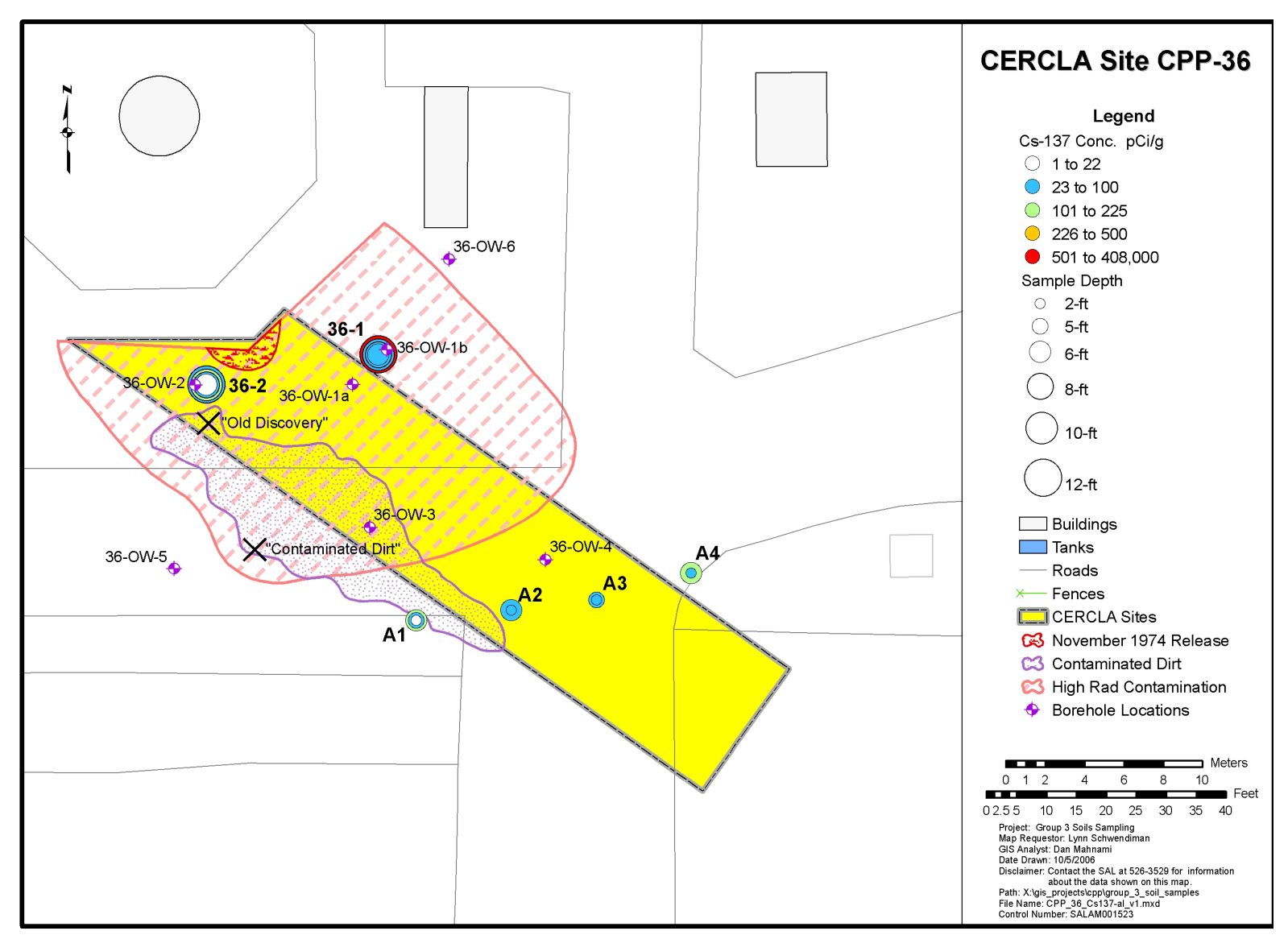

Figure A-17. CPP-36 Cs-137. 


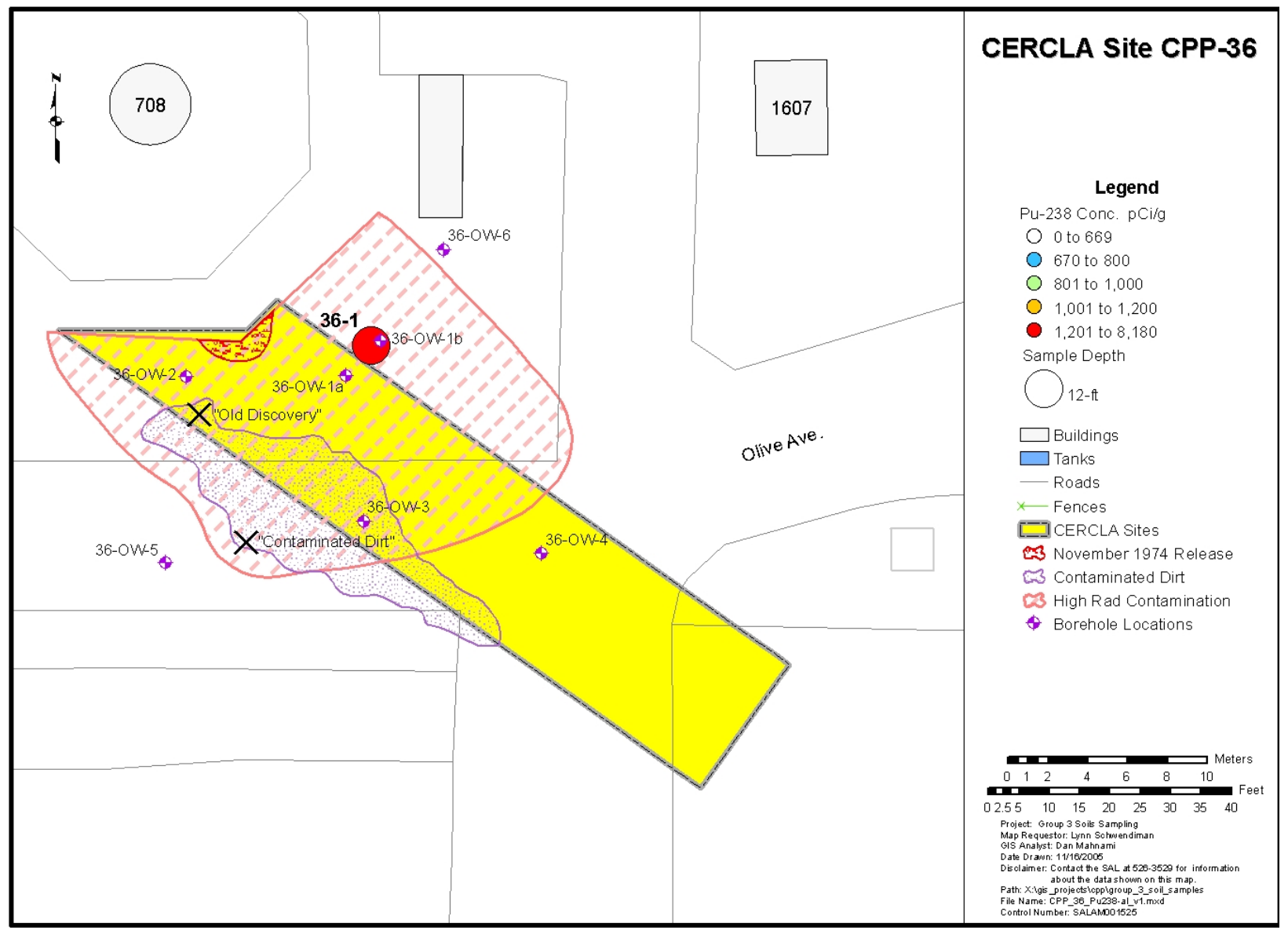

Figure A-18. CPP-36 Pu-238. 


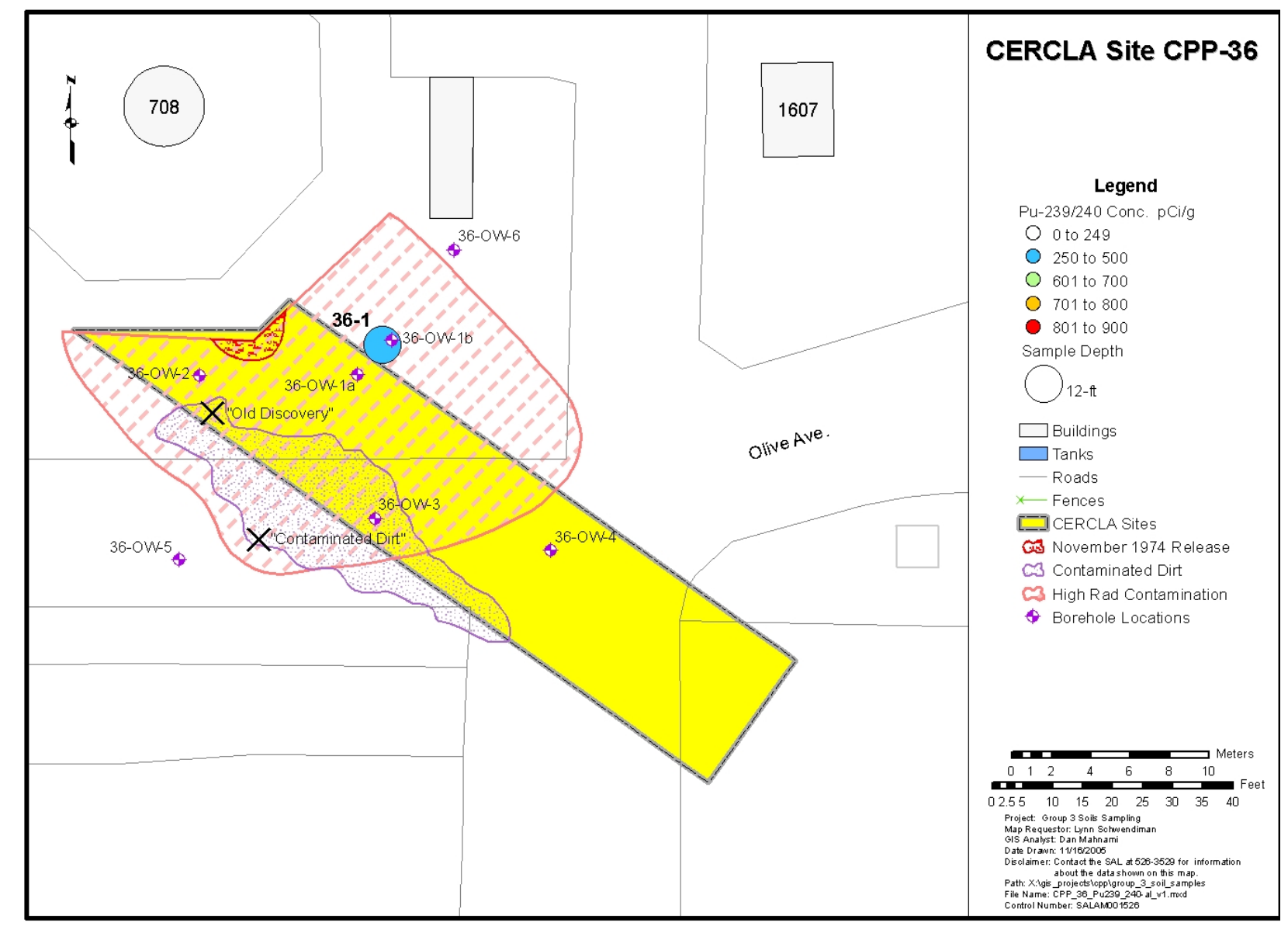

Figure A-19. CPP-36 Pu-239 and Pu-240. 


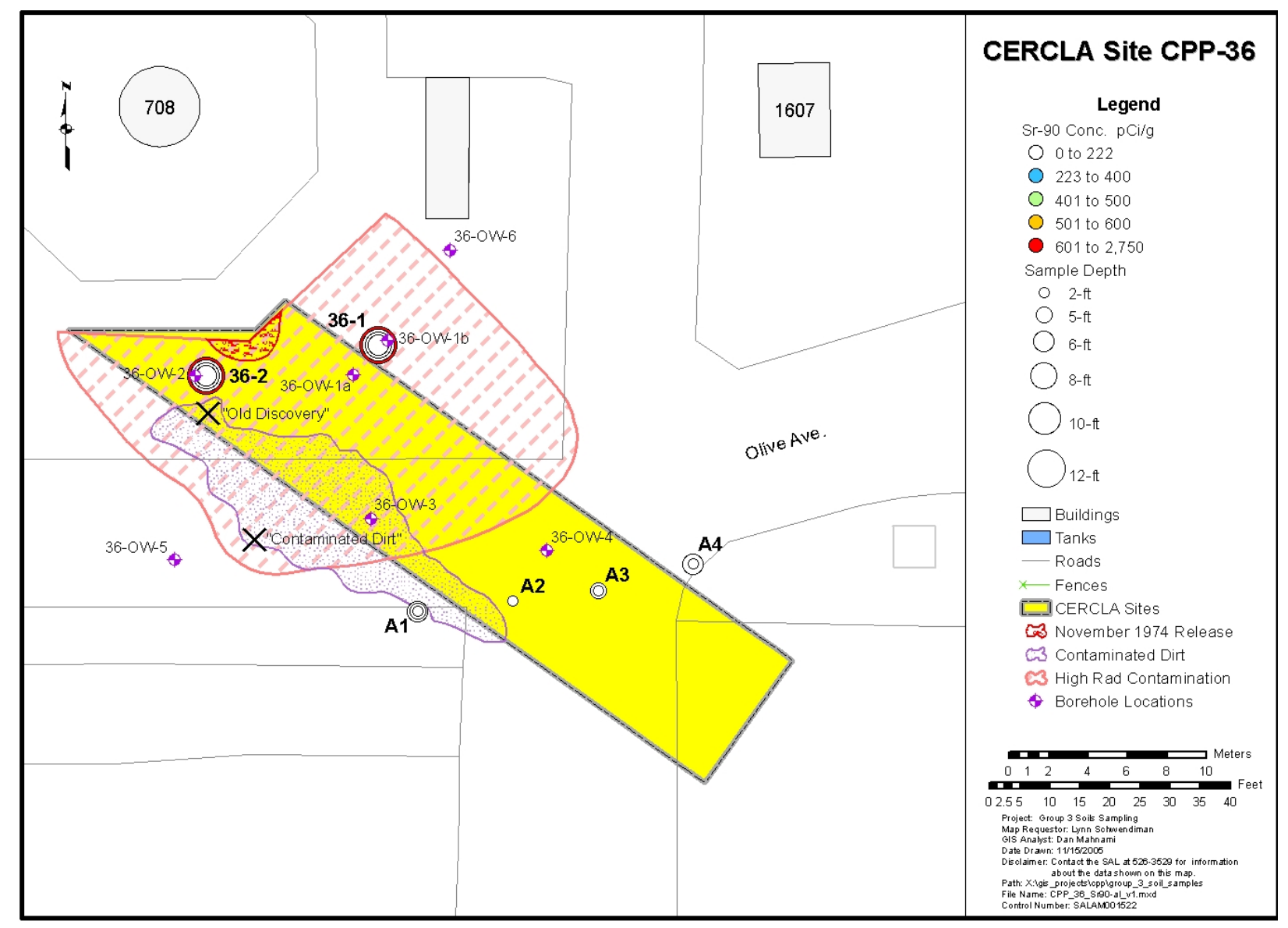

Figure A-20. CPP-36 Sr-90. 


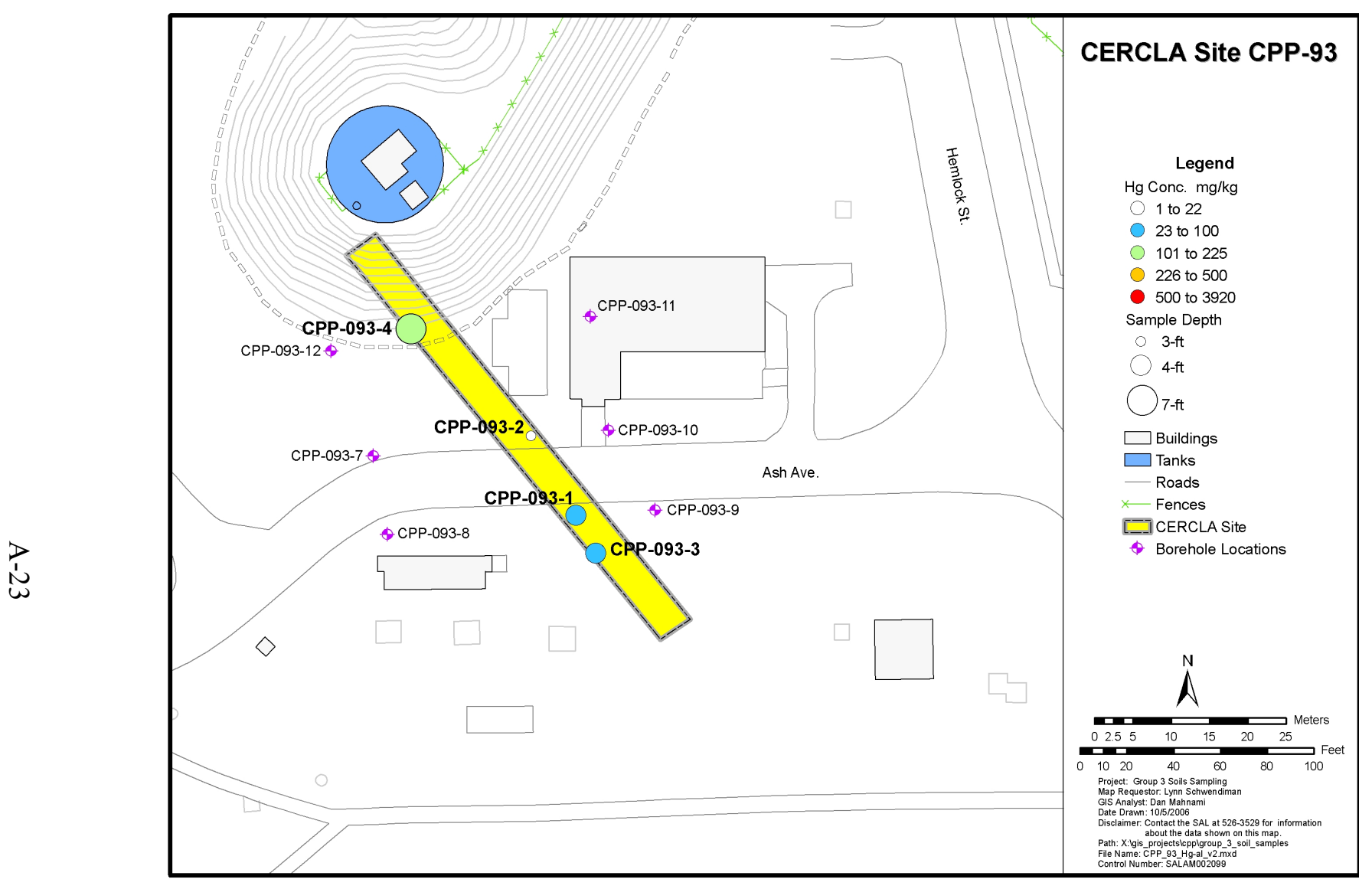

Figure A-21. CPP-93 Hg. 
Appendix B

\section{Group 3, Phase II Sites Sampling Location Figures}


B-2 


\section{Appendix B}

\section{Group 3, Phase II Sites Sampling Location Figures}

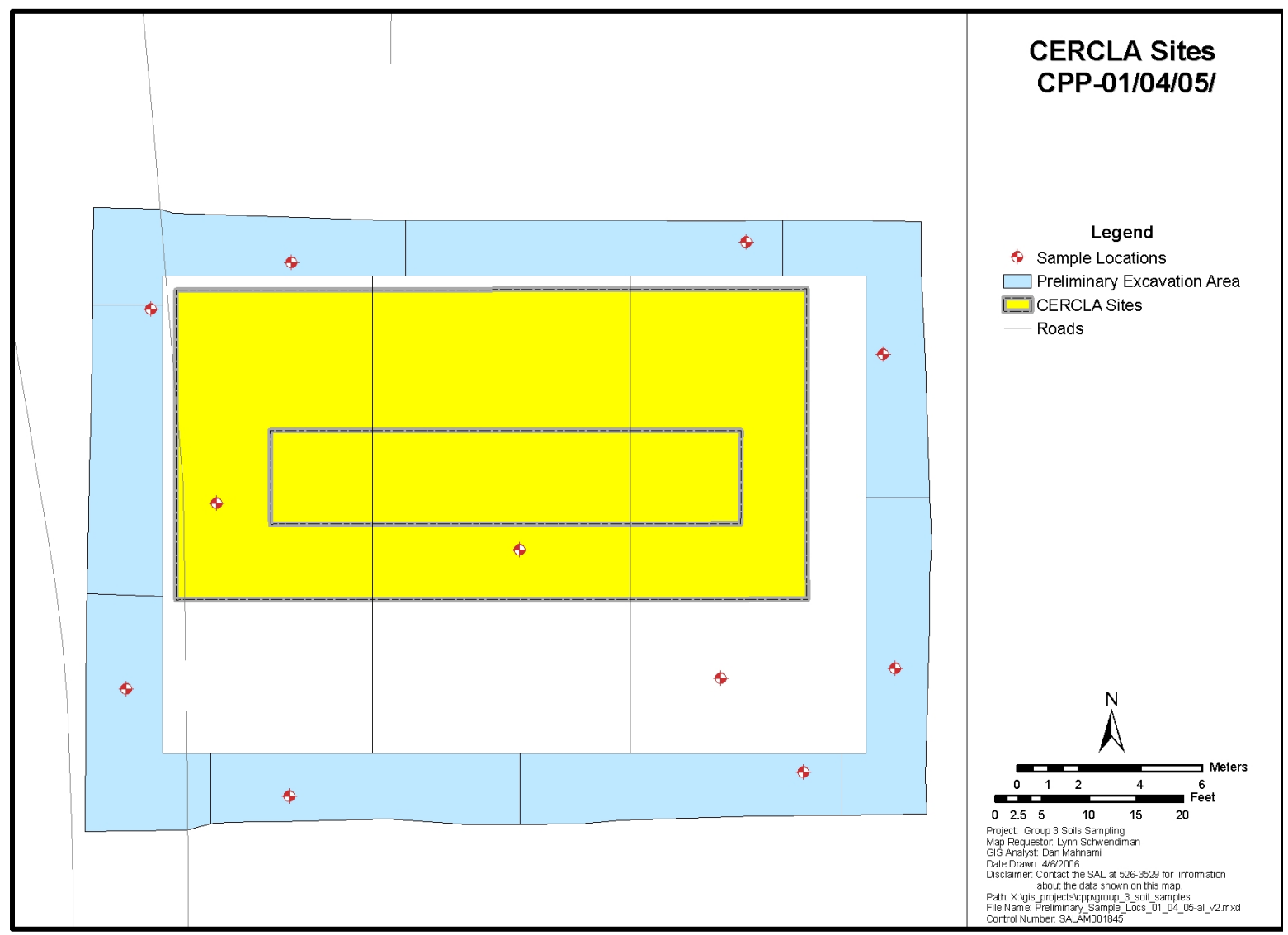

Figure B-1. CERCLA Sites CPP-01, -04, -05. 


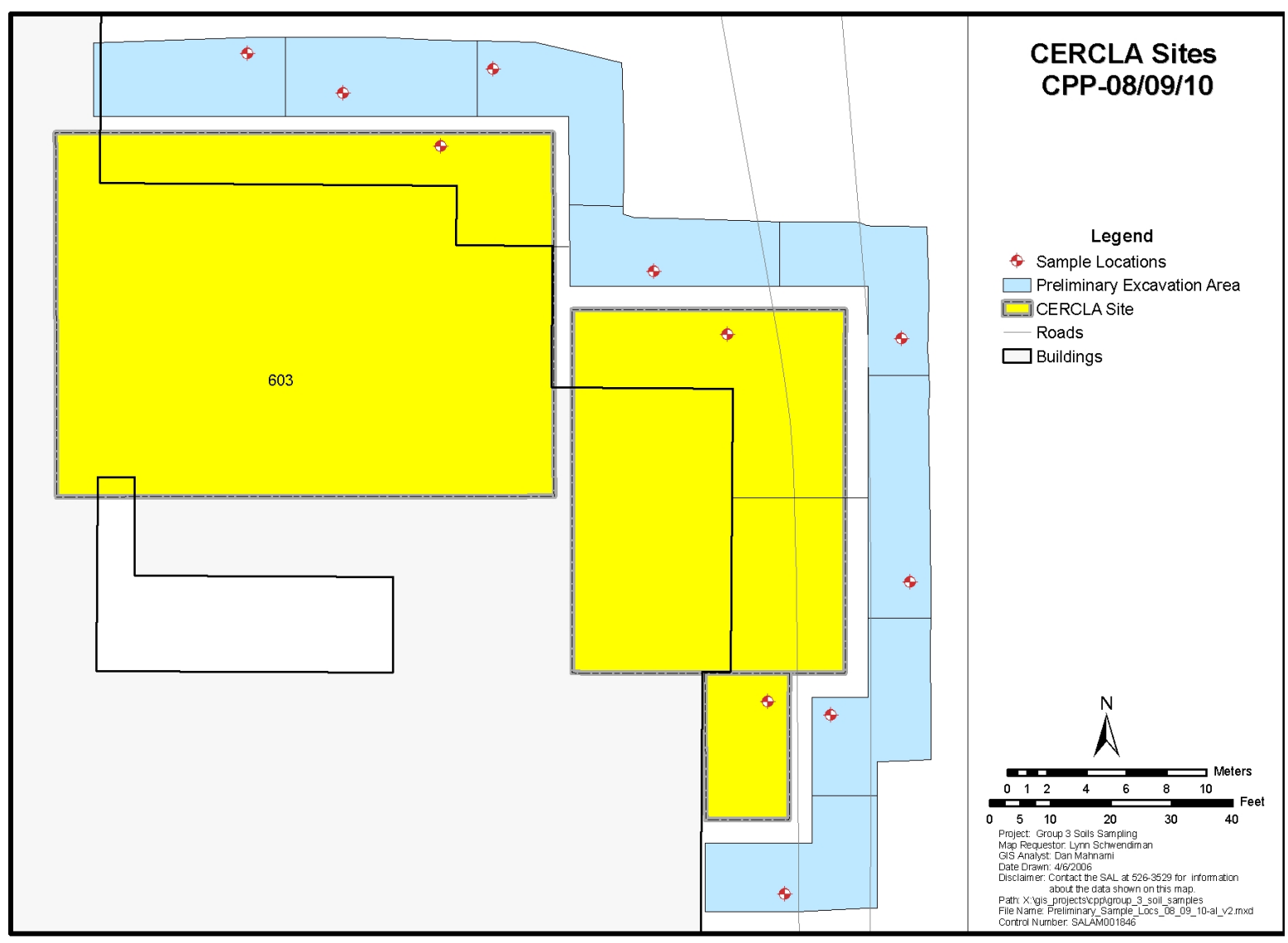

Figure B-2. CERCLA Sites CPP-08, -09, 10. 


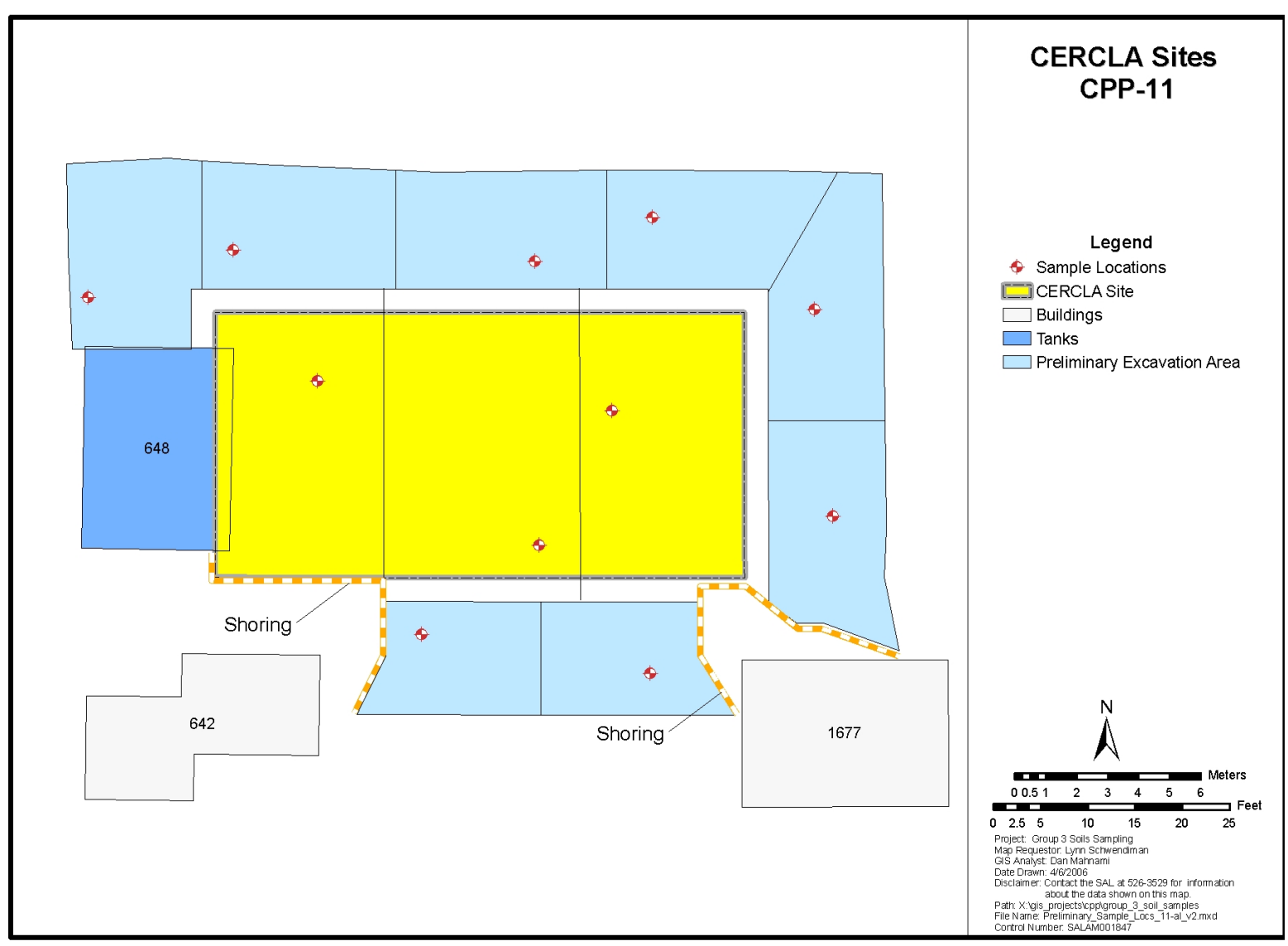

Figure B-3. CERCLA Site CPP-11. 


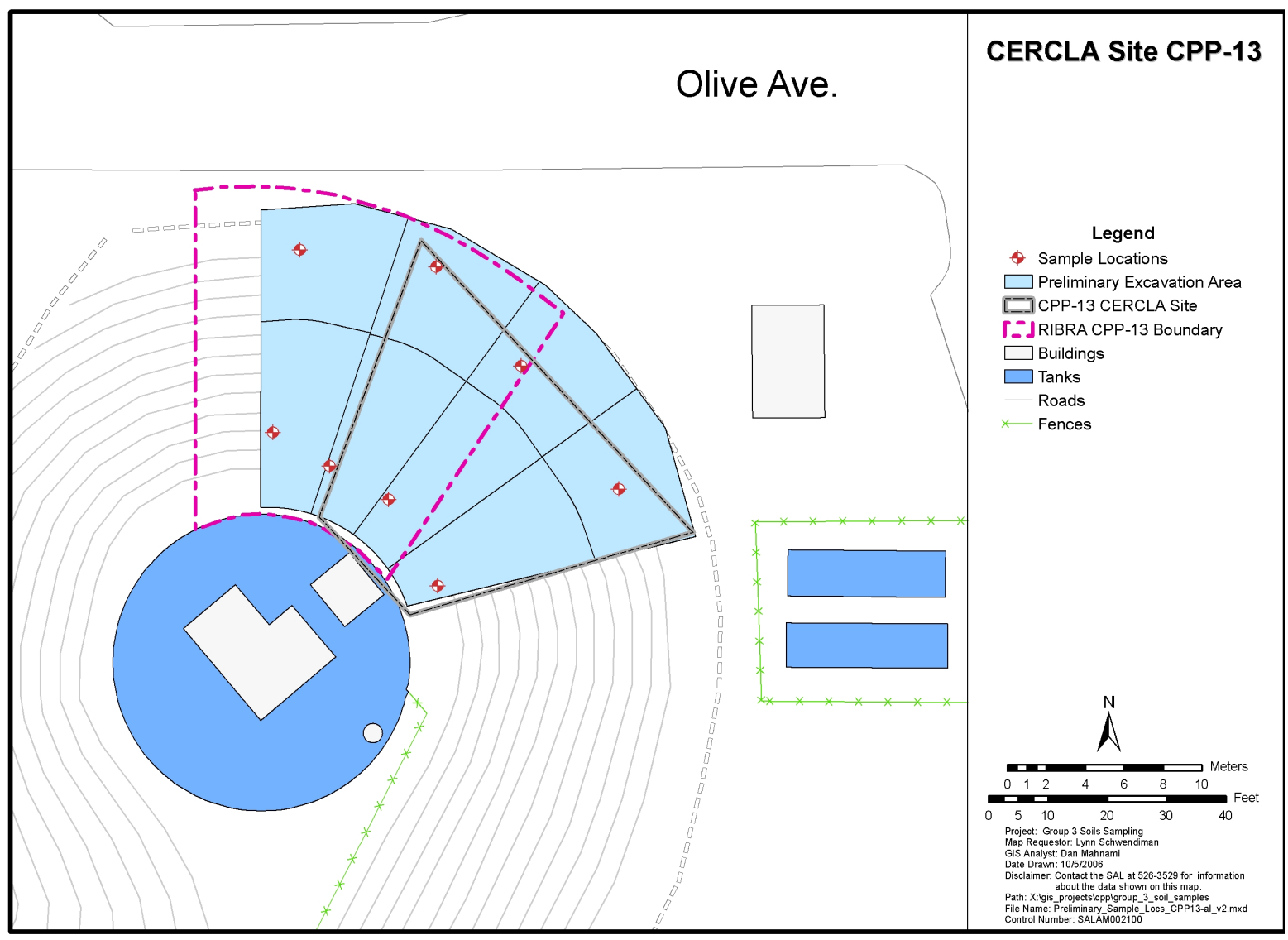

Figure B-4. CERCLA Site CPP-13. 


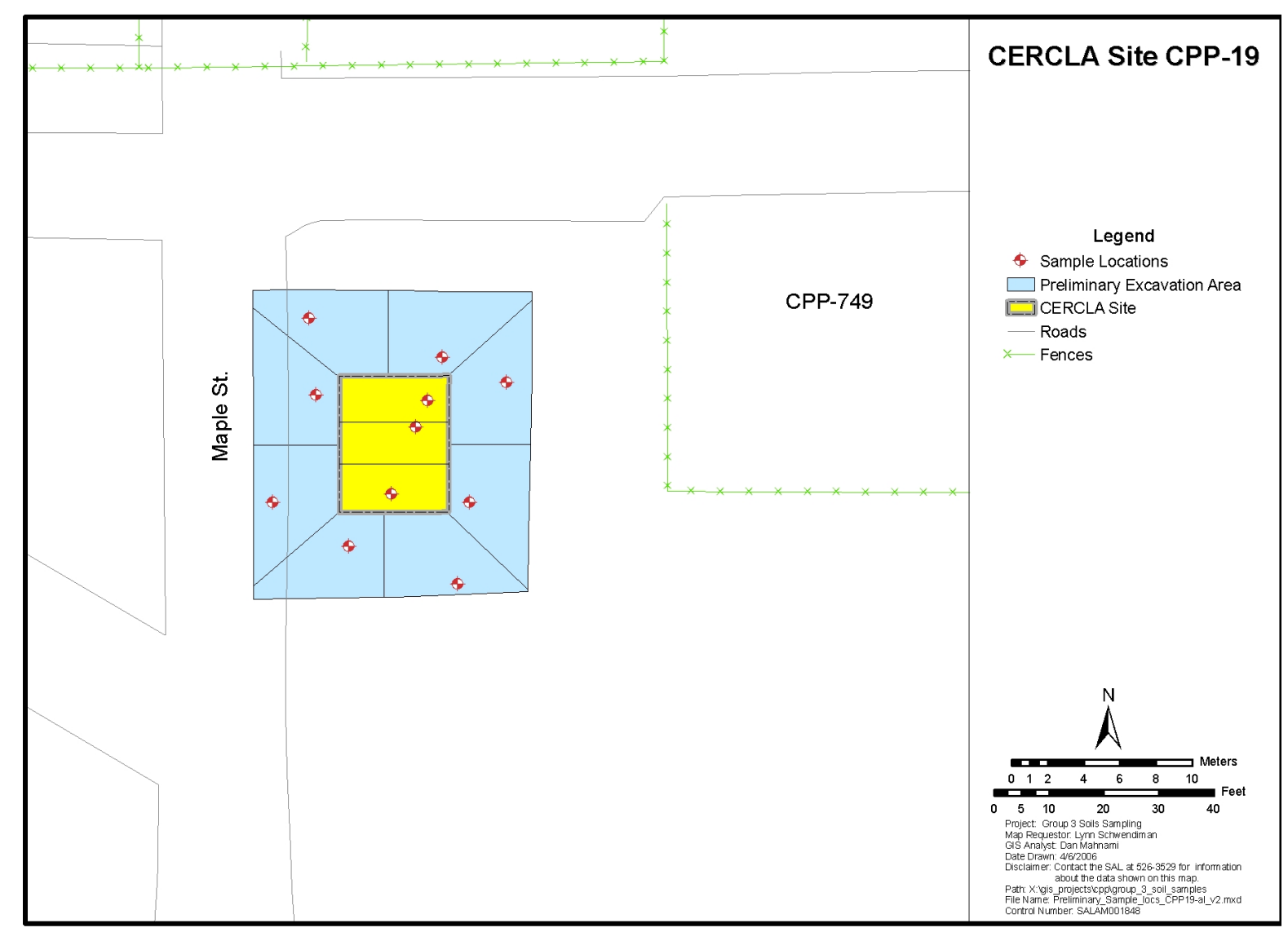

Figure B-5. CERCLA Site CPP-19. 


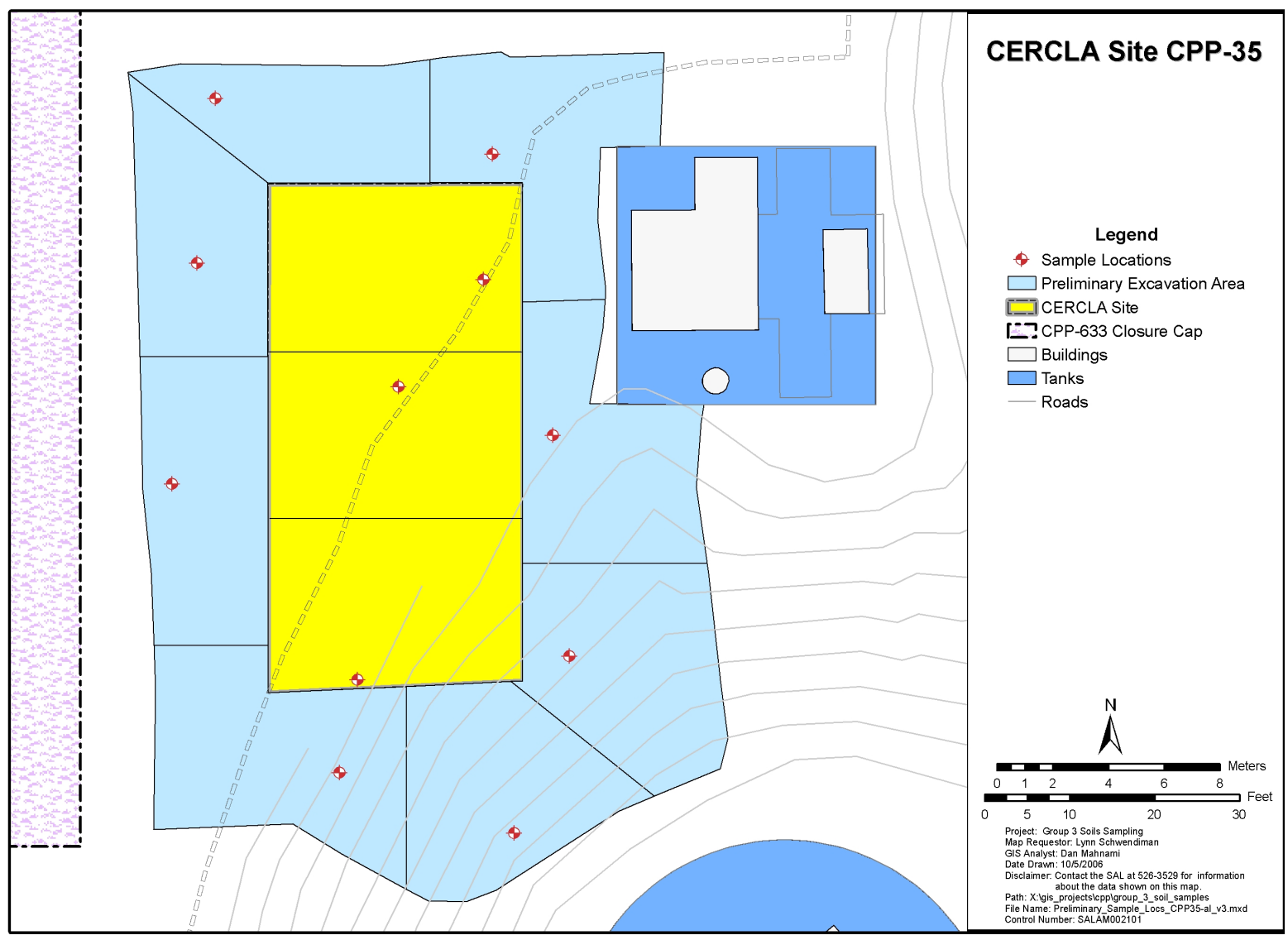

Figure B-6. CERCLA Site CPP-35. 


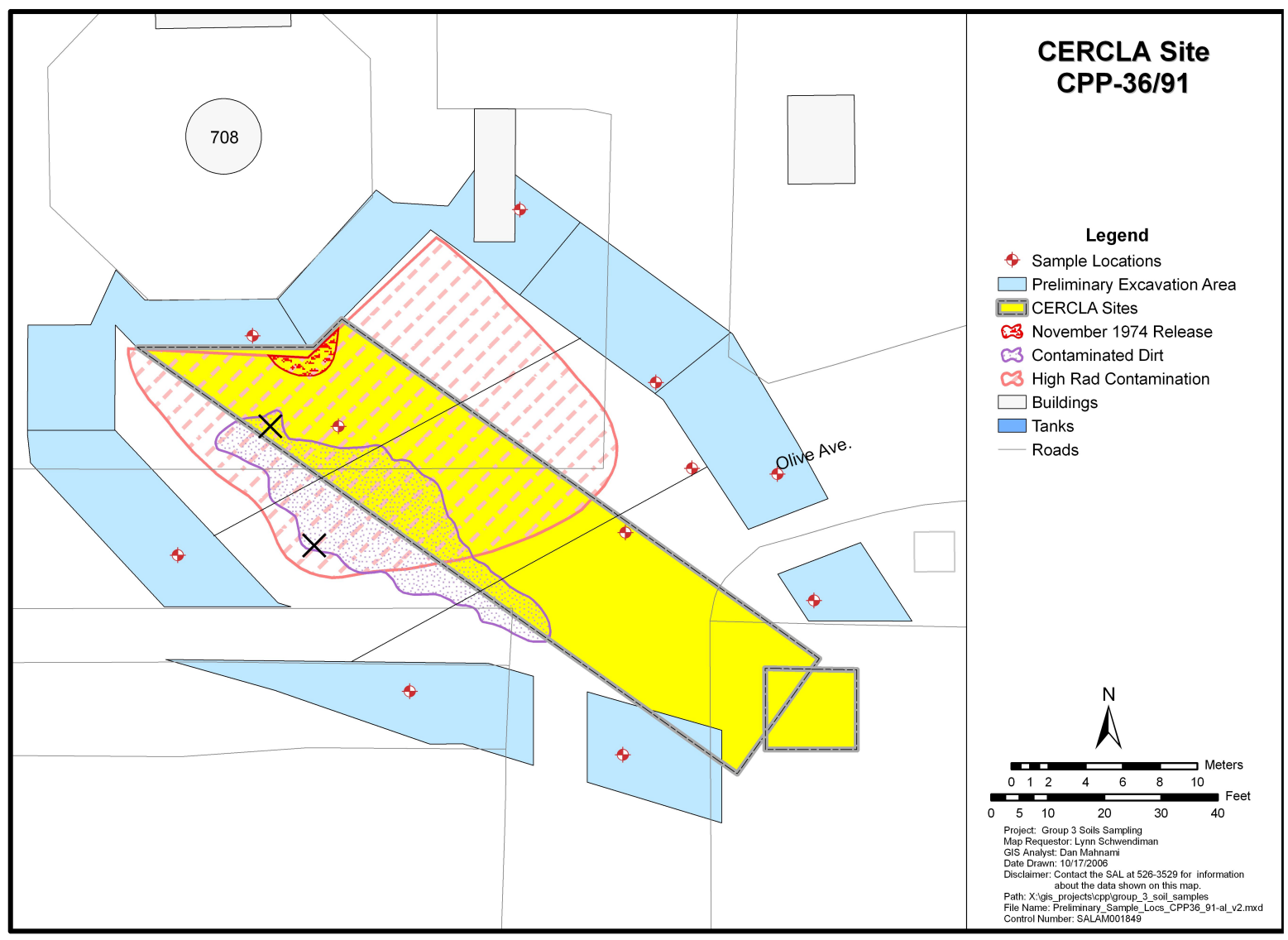

Figure B-7. CERCLA Site CPP-35/91. 


\section{Appendix C}

Sample and Analysis Plan Tables 


$$
\text { C-2 }
$$


DRAFT

Date: $\quad$ 01127/2006 Plan Table Revision: 0.0 Project: OU 3-13 PHASE II MISCELLANEOUS SOIL SITES

Project Manager: LANDIS, J.A.

Sampler: Copeland, D. F

SMO Contact KIRCHNER, D. R.

nter Analysis Types (AT) and Quantity Requested

\begin{tabular}{|c|c|c|c|c|c|c|c|c|c|c|c|c|c|c|c|c|c|c|c|c|c|c|c|c|}
\hline \multicolumn{5}{|c|}{ Sample Description } & & \multicolumn{4}{|c|}{ Sample Location } & \multicolumn{15}{|c|}{ Enter Analysis Types (AT) and Quantity Requested } \\
\hline Sampling & Sample & Sample & Coll & Sampling & Planned & & & & & AT1 & AT2 & AТ3 & AT4 & AT5 A & $\begin{array}{ll}\text { AT6 } & \text { AT }\end{array}$ & T7 AT8 & Aт9 A & AT10 AT1 & T11 AT1 & 2 AT13 A & AT14 AT & 15 AT16 A & AT17 AT18 $A$ & Aт19AT20 \\
\hline Activity & Type & Matrix & Type & Method & Date & Area & Location & Location & (t) & R4 & $\mathrm{RH}$ & & & & & & & & & & & & & \\
\hline E008006000 & REG & SOIL & GRAB & & 11 & INTEC & 603 DRY WELLS & CPP-01DW & NA & & 1 & & & & & & & & & & & & & \\
\hline E00806001 & REG & SOlL & GRAB & & 11 & INTEC & 603 DRY WELLS & CPP. $010 W$ & NA & & 1 & & & & & & & & & & & & & \\
\hline E00806002 & REG & SOIL & GRAB & & 11 & INTEC & 603 DRY WELLS & CPP.010W & NA & & 1 & & & & & & & & & & & & & \\
\hline E00800003 & REG & SOIL & GRAB & & 11 & INTEC & 603 DRY WELLS & CPP.01DW & NA & & 1 & & & & & & & & & & & & & \\
\hline E00800004 & REG & SOLL & GRAB & & 11 & INTEC & 603 DRY WELLS & CPP.01DW & NA & & 1 & & & & & & & & & & & & & \\
\hline E00800005 & REG & SOLL & GRAB & & 11 & INTEC & 603 DRY WELLS & CPP.010W & NA & & 1 & & & & & & & & & & & & & \\
\hline E00806006 & REG & SOIL & GRAB & & 11 & INTEC & 603 DRY WELLS & CPP.01DW & $\mathrm{NA}$ & & 1 & & & & & & & & & & & & & \\
\hline E00806007 & REG & SOIL & GRAB & & 11 & INTEC & 603 DRY WELLS & CPP-01DW & $\mathrm{NA}$ & & 1 & & & & & & & & & & & & & \\
\hline E00800008 & REG & SOLL & GRAB & & 11 & INTEC & 633 TANKSBBASIN & CPP-0405/01 & $\mathrm{NA}$ & 1 & & & & & & & & & & & & & & \\
\hline E00806009 & REG & SOIL & GRAB & & 11 & INTEC & 633 TANKS:BASIN & CPP-0405/01 & NA & 1 & & & & & & & & & & & & & & \\
\hline E00800010 & REG & SOIL & GRAB & & 11 & INTEC & 633 TANKSIBASIN & CPP-0405:01 & NA & 1 & & & & & & & & & & & & & & \\
\hline E00800011 & REG & SOIL & GRAB & & 11 & INTEC & 633 TANKSIBASIN & CPP-0405:01 & NA & 1 & & & & & & & & & & & & & & \\
\hline E00806012 & REG & SOIL & GRAB & & 11 & INTEC & 633 TANKSIBASIN & CPP-0405/01 & $\mathrm{NA}$ & 1 & & & & & & & & & & & & & & \\
\hline E00800013 & REG & SOLL & GRAB & & 11 & INTEC & 633 TANKSIBASIN & CPP-040501 & NA & 1 & & & & & & & & & & & & & & \\
\hline E00806014 & REG & SOIL & GRAB & & 11 & INTEC & 633 TANKSIBASIN & CPP-0405/01 & NA & 1 & & & & & & & & & & & & & & \\
\hline
\end{tabular}

The sampling activity displayed on this table represents the first 6 to 9 characters of the sample identification number. The complete sample identification number will appear on the sample labels

AT1: Gamma Spec

11:

Comments.

D. Double QC Volume T- Triple QC Volume

AT13

AT4:

AT5: $\longrightarrow$ AT15

AT6:

AT7:

AT8:

Radiochemistry - Suite 1: Gamma Spec, Sr-90

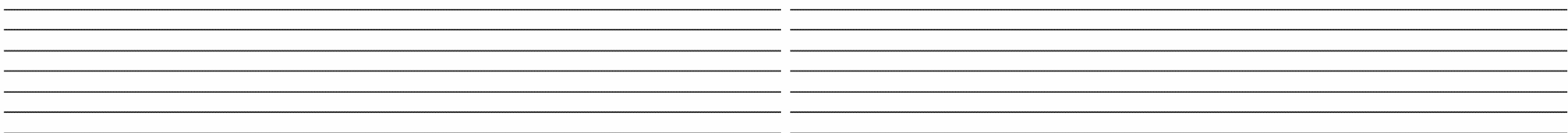


Sampling and Analysis Plan Table for Chemical and Radiological Analysis

DRAFT

SAP Number: DOEID-11256

Project Manager: LANDIS.J.A.

Date: $\quad$ 1127272006 Plan Table Revision: 0.0 Project OU 3-13 PHASE IIMISCELLANEOUS SOLL STIES

Sampler: Copeland, D. F.

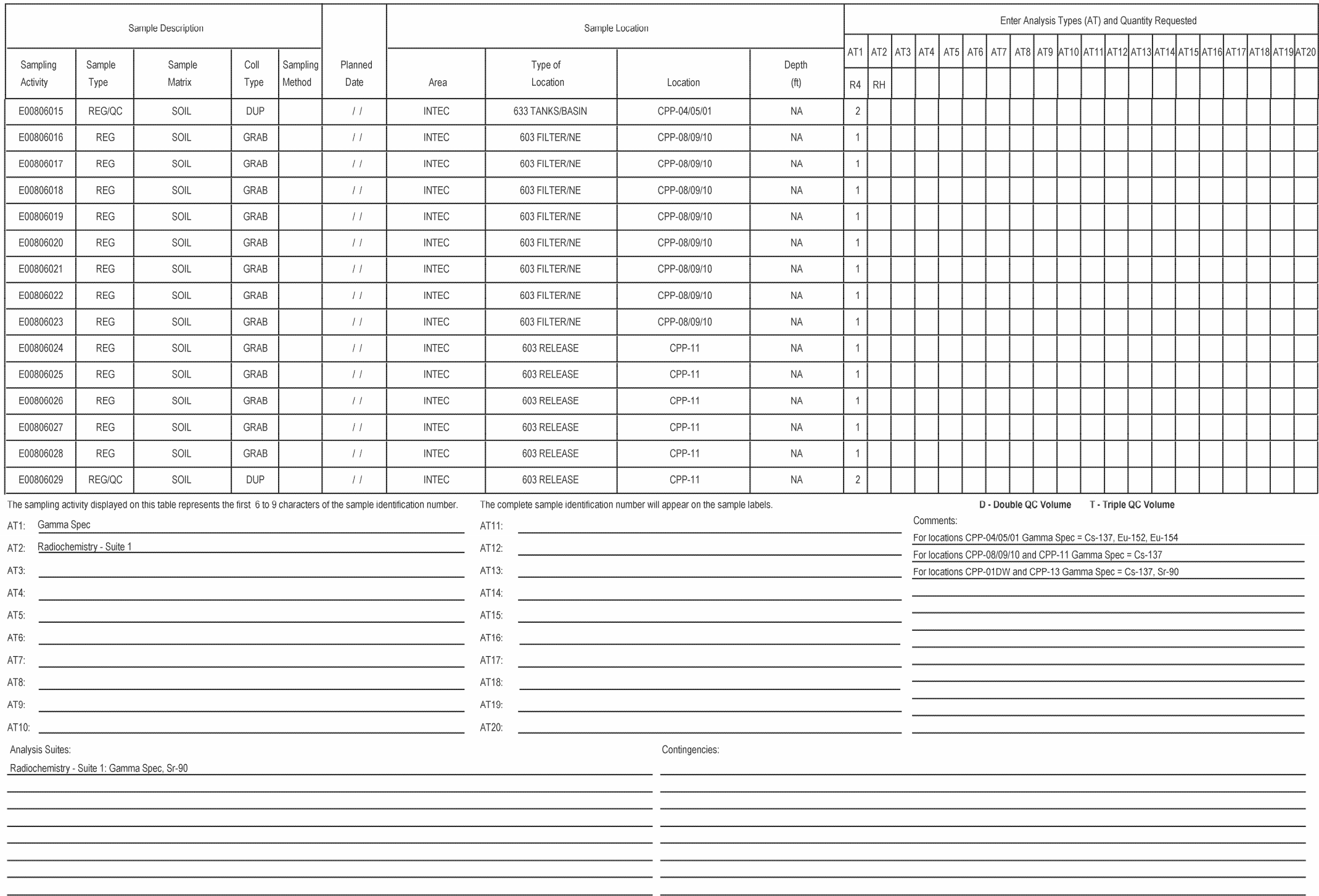




\section{DRAFT}

SAP Number: DOEND-11250

Date: $\quad$ 01/27/2006 Plan Table Revision: 0.0 Project: OU 3-13 PHASE IM MISCELLANEOUS SOIL SITES

Project Manager: LANDIS, J.A

\begin{tabular}{|c|c|c|c|c|c|c|}
\hline \multicolumn{5}{|c|}{ Sample Description } & \multirow[b]{2}{*}{$\begin{array}{l}\text { Planned } \\
\text { Date }\end{array}$} & \multirow[b]{2}{*}{ Area } \\
\hline $\begin{array}{l}\text { Sampling } \\
\text { Activity }\end{array}$ & $\begin{array}{l}\text { Sample } \\
\text { Type }\end{array}$ & $\begin{array}{l}\text { Sample } \\
\text { Martix }\end{array}$ & $\begin{array}{l}\text { Coll } \\
\text { Type }\end{array}$ & $\begin{array}{l}\text { Sampling } \\
\text { Method }\end{array}$ & & \\
\hline$E 00800030$ & REG & SOIL & GRAB & & 11 & INTEC \\
\hline E00800031 & REG & SOIL & GRAB & & 11 & INTEC \\
\hline$E 00800032$ & REG & SOIL & GRAB & & 11 & INTEC \\
\hline$E 00800033$ & REG & SOIL & GRAB & & 11 & INTEC \\
\hline E00800034 & REG & SOIL & GRAB & & 11 & INTEC \\
\hline$E 00800035$ & REG & SOIL & GRAB & & 11 & INTEC \\
\hline E00800036 & REG & SOIL & GRAB & & 11 & INTEC \\
\hline$E 00800037$ & REG & SOIL & GRAB & & 11 & INTEC \\
\hline$E 00800038$ & REG & SOIL & GRAB & & 11 & INTEC \\
\hline E00800039 & REG/QC & soll & DUP & & 11 & INTEC \\
\hline E00806040 & QC & WATER & FBLK & & 11 & INTEC \\
\hline & & & & & & \\
\hline & & & & & & \\
\hline & & & & & & \\
\hline & & & & & & \\
\hline
\end{tabular}

\section{The sampling activity displayed on this table represents the first 6 to 9 characters of the sample identification number}

AT1: Gamma Spec

AT2: Radiochemistry-Suite 1

AT3:

AT10:

Analysis Suites:

Radiochemistry - Suite 1: Gamma Seec, Sr-90
Sampler: Copeland, D.F.

SMO Contact: KIRCHNER, D.R.

Enter Analysis Types (AT) and Quantity Requested

\begin{tabular}{|c|c|c|c|c|c|c|c|c|c|c|c|c|c|c|c|c|c|c|}
\hline \multicolumn{3}{|c|}{ Sample Location } & \multicolumn{16}{|c|}{ Enter Analysis Types (AT) and Quantity Requested } \\
\hline \multirow[b]{2}{*}{$\begin{array}{l}\text { Type of } \\
\text { Location }\end{array}$} & \multirow[b]{2}{*}{ Location } & \multirow[b]{2}{*}{$\begin{array}{l}\text { Depth } \\
\text { (tt) }\end{array}$} & \multirow[t]{2}{*}{ AT1 } & \begin{tabular}{|l|l|} 
AT2 & A \\
\end{tabular} & AT3 & \begin{tabular}{|l|} 
AT4 \\
\end{tabular} & \multirow[t]{2}{*}{ AT5 } & \multirow{2}{*}{\begin{tabular}{|l|l|} 
AT6 \\
\end{tabular}} & & \multirow[t]{2}{*}{\begin{tabular}{l|l} 
AT8 & AT9
\end{tabular}} & \multirow{2}{*}{\multicolumn{2}{|c|}{ AT10 AT11 }} & \multirow{2}{*}{11 AT12 AT } & \multirow{2}{*}{\multicolumn{2}{|c|}{\begin{tabular}{|l|l|l|}
13 & AT14 & AT \\
&
\end{tabular}}} & \multirow{2}{*}{\multicolumn{3}{|c|}{\begin{tabular}{|l|l|l|l|l|l|l|}
15 & AT16 & AT17 & AT18 & AT19 & AT20 \\
& & & \\
\end{tabular}}} \\
\hline & & & & $\mathrm{RH}$ & & & & & & & & & & & & & & \\
\hline 603 RELEASE & CPP-11 & NA & 1 & & & & & & & & & & & & & & & \\
\hline 603 RELEASE & CPP-11 & NA & 1 & & & & & & & & & & & & & & & \\
\hline 633 PRESSURE & CPP-13 & NA & & 1 & & & & & & & & & & & & & & \\
\hline 633 PRESSURE & CPP-13 & NA & & 1 & & & & & & & & & & & & & & \\
\hline 633 PRESSURE & CPP-13 & NA & & 1 & & & & & & & & & & & & & & \\
\hline 633 PRESSURE & CPP-13 & NA & & 1 & & & & & & & & & & & & & & \\
\hline 633 PRESSURE & CPP-13 & NA & & 1 & & & & & & & & & & & & & & \\
\hline 633 PRESSURE & CPP-13 & NA & & 1 & & & & & & & & & & & & & & \\
\hline 633 PRESSURE & CPP-13 & NA & & 1 & & & & & & & & & & & & & & \\
\hline 633 PRESSURE & CPP-13 & NA & & 2 & & & & & & & & & & & & & & \\
\hline FIELD BLANK & QC & NA & & 1 & & & & & & & & & & & & & & \\
\hline & & & & & & & & & & & & & & & & & & \\
\hline & & & & & & & & & & & & & & & & & & \\
\hline & & & & & & & & & & & & & & & & & & \\
\hline & & & & & & & & & & & & & & & & & & \\
\hline
\end{tabular}

Comments

D - Double QC Volume T- Triple QC Volum

For locations CPP-0405101 Gamma Spec $=$ Cs-137, Eu-152, Eu-154

For Hocations CPP-0809910 and CPP-11 Gamma Spec $=$ CS-137

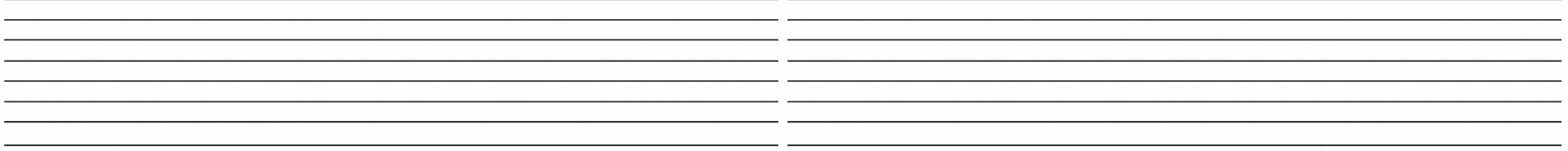




\section{Attachment 1}

\section{Job Safety Analysis}


Att1-2 
Attachment 2

Hazard Screening Checklist Hazard Screening Questions 
Att2-2 